UNIVERSIDADE DE SÃO PAULO

FACULDADE DE FILOSOFIA, LETRAS E CIÊNCIAS HUMANAS.

DEPARTAMENTO DE HISTÓRIA

PROGRAMA DE PÓS-GRADUAÇÃO EM HISTÓRIA SOCIAL

\title{
O REI, O GUERREIRO E O HERÓI: BEOWULF E SUA REPRESENTAÇÃO NO MUNDO GERMÂNICO.
}

Elton Oliveira Souza de Medeiros

Dissertação apresentada ao Programa de PósGraduação em História Social, do Departamento de História da Faculdade de Filosofia, Letras e Ciências Humanas da Universidade de São Paulo, para a obtenção do título de Mestre em História.

Orientador: Prof. Dr. Nachman Falbel. 
UNIVERSIDADE DE SÃO PAULO

FACULDADE DE FILOSOFIA, LETRAS E CIÊNCIAS HUMANAS.

DEPARTAMENTO DE HISTÓRIA

PROGRAMA DE PÓS-GRADUAÇÃO EM HISTÓRIA SOCIAL

O REI, O GUERREIRO E O HERÓI: BEOWULF E SUA REPRESENTAÇÃO NO MUNDO GERMÂNICO.

Elton Oliveira Souza de Medeiros

São Paulo

2006 
DEDICATÓRIA

Dedico esta dissertação à minha família e em especial à memória de minha avó paterna Sinezia Souza de Medeiros. 
AGRADECIMENTOS

Agradeço à minha família, meus amigos e todos aqueles que contribuíram com apoio e (principalmente) paciência.

Agradeço em especial ao Professor Nachman Falbel por sua presença e apoio constantes. 


\section{RESUMO}

Através deste trabalho, pretendemos analisar o poema Beowulf e sua importância na sociedade da Inglaterra anglo-saxônica, em especial no que se refere às imagens aristocráticas e régias.

Estabelecemos paralelos das personagens encontradas no poema e demais referencias do corpo poético anglo-saxão, com o quadro sócio-cultural do momento tendo por foco o período chamado em nossa pesquisa por período alfrediano. Segundo nossa hipótese, teria sido dentro deste período (final do século VIII e início do século XI) que provavelmente Beowulf teria sido composto, assim como outras obras de cunho heróico. A idéia central seria de que tais obras teriam uma finalidade modelar para a aristocracia guerreira durante o momento da reconquista dos territórios ocupados pelos escandinavos desde o início das primeiras invasões. Assim, as imagens encontradas nessas obras e em especial Beowulf, estariam espelhando um ideal aristocrático germânico, mas profundamente influenciado pela tradição cristã.

Desta forma, o que teremos será uma produção poética incentivada pela ascensão da Casa de Wessex (iniciada pelo rei Alfred, o Grande) que irá refletir o ideário germânico de glória e honra unido a elementos cristão, principalmente do Velho Testamento. Ao reforçar tais elementos, o período alfrediano estabeleceria um modelo aristocrático e régio, tendo o poema Beowulf como um reflexo desta retomada cultural numa Inglaterra pré-conquista normanda.

Palavras-chave: Inglaterra, Beowulf, Anglo-saxões, Aristocracia, Sociedade. 


\begin{abstract}
With this work, we intend to study the Beowulf poem and its importance on Anglo-Saxon society, mainly about the kingship and aristocratic images.

We established some parallels of what could be found in the poem and other references of the Anglo-Saxon poetic staff, with the socio-cultural scenario of the age keeping on focus the moment that we call alfredian period. Following our hypothesis, it would have been on this period (end of 8th century and early 11th century) that Beowulf would have been composed, as other works of heroic style. The central idea is that such works had the purpose to be a role model to the warrior-aristocracy in a moment of reconquering of the territories occupied by the Scandinavians since the beginning of the invasions. So, the images found on this kind of work, and specially Beowulf, would have been a resemblance of a Germanic aristocratic ideal, but deeply influenced by the Christian tradition.

With this in mind, what we have are a poetic enterprise supported by the ascension of the House of Wessex (started by king Alfred, the Great) which will reflect the Germanic ideal of glory and honor joined with Christian elements, mainly from the Old Testament. With the stressing of this elements, the Alfredian period would established an aristocratic and kingly model, having the Beowulf poem as a sign of this cultural renascence on an England before the Norman conquest.
\end{abstract}

Key Words: England, Beowulf, Anglo-Saxons, Aristocracy, Society. 
"E essa é a Imagem na qual estão contidas todas as outras imagens: a imagem que pode ser vista por toda parte e em todas as formas. Mas o que vemos é tão-somente o que nós mesmos nos temos esboçado a partir das reproduções com as quais estamos familiarizados. Ninguém pode ver a Imagem autêntica e real. A reprodução que lhe é mais semelhante é a do homem. Mas todos os mundos superiores e inferiores estão compreendidos na Imagem de Deus”.

Sêfer há-Zohar 


\section{SUMÁRIO}

$\begin{array}{ll}\text { Dedicatória } & 03\end{array}$

$\begin{array}{ll}\text { Agradecimentos } & 04\end{array}$

Resumo/ Palavras-Chave 05

Abstract/ Key Words 06

$\begin{array}{ll}\text { Sumário } & 08\end{array}$

Índice $\quad 09$

$\begin{array}{ll}\text { Índice Iconográfico } & 10\end{array}$

$\begin{array}{ll}\text { Índice de Gráficos } & 10\end{array}$

$\begin{array}{ll}\text { Introdução } & 11\end{array}$

CAPITULO I - Os Monstros e o Manuscrito 17

CAPITULO II - A Casa de Wessex 39

CAPITULO III - O Rei, o Guerreiro e o Herói 92

$\begin{array}{ll}\text { Conclusão } & 119\end{array}$

Apêndices 122

Referências Bibliográficas 133 


\section{ÍNDICE}

INTRODUÇÃO

CAPITULO I - Os Monstros e o Manuscrito

$\begin{array}{ll}\text { I.1 - Cotton Vitellius A. XV } & 17\end{array}$

I.2 - O Monstro 29

CAPITULO II - A Casa de Wessex

II.1 - A presença escandinava na Inglaterra 39

II.2 - A linhagem de Cerdic $\quad 61$

II.3 - Poesia heróica em Wessex 83

CAPITULO III - O Rei, o Guerreiro e o Herói

III.1 - A aristocracia guerreira $\quad 92$

III.2 - As qualidades aristocráticas $\quad 96$

$\begin{array}{ll}\text { III.3 - A imagem do rei } & 104\end{array}$

III.4 - O modelo aristocrático: Beowulf 116

$\begin{array}{lr}\text { CONCLUSÃO } & 119\end{array}$

APÊNDICES

APÊNDICE I - Corpo Poético da Inglaterra Anglo-Saxônica 123

APÊNDICE II - Mapa da Inglaterra Anglo-Saxônica, século IX. 126

APÊNCICE III - Guerreiros $\quad 127$

APÊNDICE IV - Genealogia da Casa de Wessex 129

$\begin{array}{ll}\text { REFERÊNCIAS BIBLIOGRÁFICAS } & 133\end{array}$ 


\section{ÍNDICE ICONOGRÁFICO}

1. Cotton Vitellius A. XV, manuscrito de Beowulf, fol. 129r 28

2. Mapa da geografia de Beowulf (Klaeber) 40

3. Mapa da geografia de Beowulf (atualizado) 41

4. O elmo de Sutton Hoo

5. Vida do Rei Alfred, por Asser, do Cotton Otho A. XII (c. 1000). 65

6. Regula Pastoralis $\quad 85$

7. Arca de Noé (Codex Junius 11, fol. 66r). 91

8. Salões reais germânicos $\quad 95$

9. O cetro de Sutton Hoo. 103

10. Caim como rei (Codex Junius 11, fol. 57r). 113

11. Mapa da Inglaterra Anglo-Saxônica, século IX. 126

12. Guerreiro escandinavo, séculos VI - VII. 127

13. Guerreiro anglo-saxão, século VIII. 128

ÍNDICE DE GRÁFICOS

Gráfico 1: Evolução do poema Beowulf $\quad 70$

Gráfico 2: Produção Cultural na Inglaterra $\quad 82$ 


\section{INTRODUÇÃO}

Desde sua primeira edição em 1815, Beowulf é alvo das mais diversas análises de enfoque: data, origem, autoria; público; critica literária; estilo, fontes; analogias; estrutura; elementos pagãos e cristãos; mito e história; simbolismo e alegoria e etc.

Até início do século XX, os estudos em torno de Beowulf estiveram por vezes ligados a uma visão romântica do século XIX, sendo submetido a estudos filológicos e históricos, preocupados em encontrar a “realidade” por trás do poema. Devido a isso, Beowulf foi vitima de tentativas de identificações históricas, como por exemplo, a idéia da "geografia de Beowulf" de Klaeber; ou ainda estudos puramente teóricos e lingüísticos que ignoravam o poema ou o manuscrito ${ }^{1}$ em si em favor de teorias que surgiam de meras suposições criadas pelos próprios pesquisadores ${ }^{2}$. Entretanto, dentro desta tradição de estudos do poema, existem algumas obras de destaque que contribuíram em muito para o desenvolvimento de uma linha de pesquisas sérias e coerentes de Beowulf. Sem a pretensão de estabelecer um ensaio sobre toda esta tradição Beowulfiana (o que renderia por si só uma outra dissertação), podemos citar alguns principais nomes ao longo deste tempo dos estudos de tal obra poética e, principalmente, que nos influenciaram durante o desenvolvimento deste trabalho.

Um dos primeiros trabalhos sobre Beowulf é o de F. A. Blackburn, de $1897^{3}$. Juntamente com ele, também podemos citar o de H. Munro Chadwick, de $1917^{4}$. Estes representam os primeiros ensaios críticos a se preocupar mais com as origens do poema de forma geral, e não as típicas especulações historiográficas ou literárias do século XIX que permeavam estes estudos. Nestes trabalhos ambos concordam numa origem pagã do poema, o qual teria passado por certas mudanças nas mãos de algum poeta cristão em algum monastério para adequar a obra a nova fé. O autor/editor do poema teria extrapolado, demonstrando até mesmo certa artificialidade (ou assim os dois ensaístas acreditavam) ao introduzir as imagens cristãs do poema ao tentar encobrir sinais pagãos, o que acabou trazendo inconsistências à narrativa. Em sua concepção, o poeta teria pouca habilidade com a temática cristã, indicando talvez um recém-converso. Por outro

\footnotetext{
${ }^{1}$ KIERNAN, 1997, p. 9.

${ }^{2}$ WHITELOCK, 1964, pp. 67-70.

${ }^{3}$ BLACKBURN, 1966, pp. 1-22.

${ }^{4}$ CHADWICK, 1966, 23-34.
} 
lado Levin L. Schücking ${ }^{5}$ e Marie Padgett Hamilton ${ }^{6}$, não viam o autor como um mero editor cristão de obras pagãs e sem muita habilidade no que fazia. Ao contrário de seus antecessores, Schücking e Hamilton viam presente no poema todo um antigo código moral de conduta, remanescente dos tempos germânicos pagãos, e um autor que teria efetivamente trabalhado de forma consciente na adequação desta velha tradição para a ambientação da teologia cristã. Schücking identifica que a noção de realeza presente no poema é justamente a imagem definida pela literatura cristã e seus paralelos da cultura greco-latina; imagens como a do rex justus e demais elementos germânicos sob a influência agostiniana.

Tendo um outro enfoque sobre Beowulf, temos em 1936 o ensaio de J. R. R. Tolkien ${ }^{7}$. Este trabalho é reconhecidamente um marco nos estudos de Beowulf, ao valorizar o poema como um todo, principalmente em relação a seu significado e valor. Tolkien destaca a condição humana e a relaciona com elementos artísticos como “equilíbrio entre inicio e fim”, o contraste entre juventude e velhice, com os monstros personificando as forças do mal e do caos e colocados no centro da narrativa de forma apropriada. Com este seu trabalho, Tolkien trouxe uma nova luz sobre o poema salvando-o da tradição de literatos e historiadores que apenas “dissecavam-no”, analisando a obra como partes ao invés de ver Beowulf como um todo, e não como uma mera fantasia folclórica ou relato histórico ${ }^{8}$. A inovação na abordagem de Tolkien foi justamente pela análise do poema em sua unidade e por sua verdadeira natureza: uma obra artística poética. A influência deste ensaio será mais tarde reforçada na década de 80, principalmente no campo da história literária e semiótica, onde Beowulf já não é mais estudado como causa, mas como efeito; o poema como reflexo artístico do período no qual surgiu e não mera alegoria histórica.

Outros trabalhos como os de Kemp Malone ${ }^{9}$, Morton W. Bloomfield ${ }^{10}$, H. L. Rogers $^{11}$, Herberth G. Wright ${ }^{12}$, R. E. Kaske ${ }^{13}$ e Margareth E. Goldsmith ${ }^{14}$ terão certa similaridade com Tolkien no que se refere a sua atenção voltada para o sentido, imagens

\footnotetext{
${ }^{5}$ SCHÜCKING, 1966, pp. 35-50.

${ }^{6}$ HAMILTON, 1966, pp. 105-136.

${ }^{7}$ TOLKIEN, 1997, pp. 5-48.

${ }^{8}$ LERER, pp.329-330.

${ }^{9}$ MALONE, 1966, pp. 137-154.

${ }^{10}$ BLOOMFIELD, 1966, pp. 155-164.

${ }^{11}$ ROGERS, 1966, pp. 233-256.

${ }^{12}$ WRIGHT, 1966, pp. 257-268.

${ }^{13}$ KASKE, 1966, 269-310.

${ }^{14}$ GOLDSMITH, 1966, pp. 373-386.
} 
e valores encontrados em Beowulf. De forma geral todos eles tratam a forma como o antigo “código germânico” se apresenta no poema dentro da tradição cristã juntamente com a valorização da imagem heróica e de nobreza. Dentre eles, talvez o mais importante seria o trabalho de Kaske, amplamente influenciado pelo trabalho de Ernst Curtius $^{15}$. Em Kaske encontraremos a idéia central do poema, em especial das personagens, baseadas no conceito de sapientia et fortitudo, estabelecendo assim um paralelo entre o cristianismo e o paganismo germânico.

Também não devemos esquecer do trabalho de Dorothy Whitelock ${ }^{16}$, que influenciou em muito a metodologia dos estudos de Beowulf no que se refere às origens do poema. Whitelock em seu trabalho argumenta contra os ditos “críticos” (como Tolkien os chamava), e dando margem para novas abordagens que saíssem das antigas formas de pesquisas remanescentes desde os tempos de Thorkelin. Além disso, o enfoque de seu trabalho se dirige a um aspecto do poema que acabará por ser muito utilizado em pesquisas futuras ${ }^{17}$ : o público; ou seja, a quem se direcionava o poema. Este conjunto de abordagens acabou por influenciar as mais recentes pesquisas, inclusive a de John D. Niles ${ }^{18}$, na qual parte de nosso trabalho se inspirou ao levantar a possibilidade de uma datação mais tardia do poema como também ao lidar com a questão mítico-histórica da obra.

Beowulf é um dos documentos do período anglo-saxão da Inglaterra mais estudado. Podemos arriscar em dizer que nove entre dez pesquisadores do período (entre historiadores, literatos e etc.) acabam por lidar com o poema. Entretanto, apesar de podermos dizer que exista uma tradição de pesquisa em relação a Beowulf, até então parece ter surgido mais perguntas que respostas. É como se para cada possível solução que tivéssemos para o poema, outras duas perguntas surgissem. Este fenômeno pode ser visto se acompanharmos o histórico de Beowulf desde que Thorkelin editou sua primeira edição do poema até hoje ${ }^{19}$.

É curioso observarmos que um poema que fascina a tantos e por tanto tempo ainda tenha tanto a nós dizer. É como se, à imagem do próprio Grendel, o poema

\footnotetext{
${ }^{15}$ CURTIUS, 1996.

${ }^{16}$ WHITELOCK, 1964.

${ }^{17}$ PAGE, 1997, p. 113.

18 NILES, 1998, pp. 213-232.

${ }^{19}$ Ver MITCHELL, Bruce \& ROBINSON, Fred C. Beowulf, Oxford: Blackwell, 1998; CHASE, Collin. The Dating of Beowulf, Toronto: Toronto University Press, 1997; BJORK, Robert E. \& NILES, John D. A Beowulf Handbook, Lincoln: Nebraska University Press, 1998; ORCHARD, Andy. A Critical Companion to Beowulf, Cambridge: D.S.Brewer, 2004.
} 
Beowulf fosse também um monstro. Assim, podemos dizer que o poema Beowulf é uma grande quimera. Uma criatura formada por diversas partes tornando extremamente difícil defini-lo como algo em específico: poema épico elegia, mero entretenimento, historia moralizante? Ele possui elementos de várias origens que o compõe, seu estilo é temporalmente impreciso, sua estrutura do idioma possui variações de diversas partes da Inglaterra; ou seja, ele é um enigma. Seria o poema uma obra pagã, fruto de uma tradição oral, ou é uma criação original de tempos cristãos sobre um tema da tradição germânica pré-migrações, ou ambos? Não existem outras versões do poema anteriores ao manuscrito de Beowulf, o poema não é citado por outras fontes da época, o nome da personagem homônima do poema também não aparece em nenhum outro documento (o que existem são apenas conjecturas, mas que não se sustentam por si só); o próprio manuscrito que chegou até nós (que por acaso foi mantido guardado em um mosteiro durante todo o período medieval) foi compilado por duas pessoas diferentes (fato que pode ser visto pela diferença da caligrafia a partir da metade do poema), é possível que religiosos do mosteiro onde o manuscrito foi encontrado devem tê-lo copiado de um exemplar que se perdeu.

Além disso, sua datação (do manuscrito) gira em torno do ano 1000, ou melhor, dizendo, algo entre meados do século X e XI. O que podemos delimitar entre os reinados do rei Athelstan e Cnut, o Grande, período muito propício para a construção da narrativa, com a ascensão da Casa de Wessex e maior desenvolvimento intelectual, retardado apenas durante as novas incursões escandinavas, e com uma realeza em contato com o continente (o que nos remete a algumas possíveis influências extraInglaterra, talvez até mesmo de fontes latinas. Sabemos que a Eneida de Virgilio já era conhecida na Inglaterra do final da era anglo-saxônica). Temos também a presença de imagens do Velho Testamento, onde podemos fazer paralelos da figura de Beowulf e seu combate contra Grendel a de Davi e Golias. Dentro da Inglaterra temos construções semelhantes a Beowulf em outros poemas como o Êxodo (versão adaptada do livro bíblico para o inglês-antigo) onde a forma como é apresentada a figura de Moisés nos faz lembrar muito de Beowulf (isso sem falar em diversas outras fontes contemporâneas a ele).

Uma forte possibilidade é de que Beowulf nunca tenha existido de outra maneira senão como nós a conhecemos hoje (no máximo uma forma muito semelhante). Ele remete a narrativas e elementos do período migratório, e devem ter sido espalhados pela Inglaterra desde então, mas sempre soltos (um indício forte é a passagem de Beowulf 
contra Grendel e depois contra o dragão; provavelmente eram histórias independentes que acabaram sendo unidas através de Beowulf). Só então, entre o século X e XI (talvez no governo do rei Athelstan) que essas narrativas são unidas através das imagens do cristianismo (em especial do Velho Testamento, extremamente popular no período; muito mais que os Evangelhos, mas seria interessante ver o poema Heliand, onde temos uma versão germanizada da figura de Cristo e dos Evangelhos). Um dos exemplos sobre o perfil do autor do poema seria justamente de um homem conhecedor tanto das antigas tradições de seus ancestrais como do mundo cristão e outras fontes. Ou seja, não era um simples pagão convertido que queria reaproveitar um poema antigo, ele sabia onde pisava e o que estava fazendo ${ }^{20}$. Por isso, Beowulf é cristão, porque independente de suas diversas fontes, ele foi construído dentro desse maëlstrom de tradições, mas num período e com intenções voltadas a um mundo cristão-germânico, onde além das passagens sobre a linhagem de Caim e a Criação, algumas palavras e representações podem ser encontradas no corpo do poema remetendo a alusões cristãs.

Para o estudo que realizamos aqui, dividimos nosso trabalho em três capítulos. No capítulo I iremos ter um primeiro contato com o documento. Um breve histórico do poema e sua origem, suas principais características e sua relação com os demais documentos que compõe o manuscrito (sua organização, seu vínculo) e a problemática do poema Beowulf frente à tradição de estudos (como por exemplo, sua autoria, local de origem, datação, público).

No capítulo II, iremos desenvolver a hipótese que iremos levantar a respeito de uma possível origem de Beowulf dentro do período da hegemonia de Wessex. Iremos mostrar de que forma seria possível o surgimento de uma obra como Beowulf entre os séculos IX e XI, e principalmente o por quê isso aconteceria justamente nesse momento. Para isso analisaremos o período em relação à política, as invasões escandinavas à Inglaterra e o que isso acarretou dentro do mundo anglo-saxão. Também demonstraremos neste período e, em decorrência dos fatos ocorridos, o surgimento de um corpo poético anglo-saxão e um possível plano, um ideal da casa de Wessex para uma Inglaterra pós-invasões vikings.

Finalmente, no capítulo III iremos analisar um elemento importante dentro deste mundo anglo-saxão e que estaria diretamente ligado ao suposto ideal criado através do corpo poético anglo-saxão: a aristocracia. Desta forma, vamos apontar as características

\footnotetext{
${ }^{20}$ TOLKIEN, 1997, pp.25-28.
} 
dessa aristocracia guerreira e principalmente de sua figura máxima: o rei. Assim, em nossa estudo, iremos analisar estes dois elementos da sociedade anglo-saxônica, como nos é apresentada em Beowulf; ou seja, uma aristocracia-guerreira e o rei germânico. Mas, além disso, por meio do estudo poético do período, também iremos ver como se faz presente uma terceira figura, diretamente ligada as duas anteriores dentro deste ideal, que é justamente o herói. 


\section{CAPÍTULO I - Os Monstros e o Manuscrito}

“O mytho é o nada que é tudo”. Fernando Pessoa, Ulysses.

\section{I.1 - Cotton Vitellius A. XV}

Dentre os manuscritos que integram o acervo do Museu Britânico, há um que deve nos chamar a atenção, um que atende pelo curioso nome Cotton Vitellius A. $X V$. Suas páginas apresentam um certo estado de deterioração, o que é acentuado devido às nítidas marcas de queimado em suas bordas. Mas é justamente nele que encontramos um dos mais antigos poemas existentes da língua inglêsa: Beowulf, que há muito desperta o interesse de pesquisadores e estudiosos.

O manuscrito como um todo teria sido reunido como o conhecemos hoje pelo antiquário Sir Robert Bruce Cotton (1571-1631), a partir de dois diferentes códices ${ }^{21}$ : Southwick Codex e o Nowell Codex. Este segundo conjunto de documentos (assim chamados devido à inscrição no topo de sua primeira página, referente a Laurence Nowell (c. 1510/20 - c. 1571), seu dono na época) é onde se encontra o documento popularmente conhecido como Beowulf.

O Cotton Vitellius A. XV (ou manuscrito de Beowulf, como também é conhecido) chegou ao Museu Britânico em 1753, tendo sobrevivido ao grande incêndio da coleção de Cotton localizada na Ashburn House, em 23 de outubro de 1731, que acabou por destruir e danificar cerca de 200 itens da coleção. Relatos dizem que alguns dos manuscritos só foram salvos por terem sido literalmente jogados pela janela. Apesar de ter escapado da destruição, as laterais das páginas do manuscrito de Beowulf foram danificadas pelo fogo, tendo assim letras perdidas, obscurecidas e irreconhecíveis. Desta forma o relato de testemunhas que haviam tido contato com o manuscrito antes e depois do incidente tornaram-se de suma importância ${ }^{22}$. Como vimos, antes do documento chegar às mãos de Sir Cotton, ele esteve com Laurence Nowell, um antiquário do século

\footnotetext{
${ }^{21} \mathrm{O}$ manuscrito em questão recebe seu nome devido, como parece claro, ao seu antigo dono Sir Cotton. Ele mantinha os manuscritos de sua coleção em estantes, tendo cada uma o busto de um imperador romano no topo. Nosso manuscrito em questão era mantido na prateleira A da estante com o busto do imperador Vitellius, sendo o décimo quinto da prateleira, logo: Cotton Vitellius A. XV

${ }^{22}$ KIERNAN, 1999, pp. 85-119.
} 
XVI. Supõe-se que Nowell, ou algum contemporâneo seu, tenha escrito a palavra feared (“aterrorizado” no inglês do século XVI) sobre a palavra em inglês antigo egsode no verso 6 de Beowulf, o que pode nos indicar que o documento estava sendo estudado e que o texto era compreendido na época. Antes de Nowell, o manuscrito teria permanecido na biblioteca de algum monastério, visto que a maior parte dos manuscritos do período da Inglaterra Anglo-Saxônica entre 1066 e a Reforma se encontravam em monastérios ${ }^{23}$. Sabemos que durante esse período o manuscrito de Beowulf despertou o interesse de ao menos dois leitores, pois há indícios de traduções de palavras do inglês-antigo para o inglês-médio no texto As Maravilhas do Oriente, um dos documentos que compõe o manuscrito ${ }^{24}$.

Apesar de Beowulf ser o mais conhecido dos documentos do manuscrito, o Cotton Vitellius A. XV contém ainda outros quatro documentos, sendo estes (em ordem como foram organizados):

1- A Paixão de São Cristóvão

2- As Maravilhas do Oriente

3- A Carta de Alexandre para Aristóteles

4- Beowulf

5- Judite.

Acredita-se que o manuscrito que se encontra no Museu Britânico seja na verdade uma cópia, ou até mesmo uma cópia de outra cópia ${ }^{25}$. Sabe-se que o manuscrito foi composto por duas pessoas diferentes (que podemos chamar de Escritor A e B). O Escritor A seria o responsável por São Cristóvão, Maravilhas do Oriente, Carta de Alexandre e Beowulf até o verso 1939 (especificamente até a palavra scyran). O restante de Beowulf e Judite foram escritos pelo Escritor B.

Uma das primeiras grandes contribuições para o estudo do manuscrito de Beowulf se deu com Humfrey Wanley, que copiou e publicou os versos 1-19 e 53-73 em 1705 (auxiliando leituras após o incêndio); outra grande contribuição foi a do islandês Grímur Jónsson Thorkelin (1752-1829), apesar de seu primeiro contato com o documento ter sido após o incêndio. Em 1787 Thorkelin pediu que fosse feita uma cópia do documento, e em 1789 ele mesmo fez uma segunda cópia. A partir dessas duas cópias (conhecidas como Thorkelin $A$ e $B$ ) ele produziu a primeira edição do poema

\footnotetext{
${ }^{23}$ MITCHELL \& ROBINSON, 1998, p. 4.

${ }^{24}$ MITCHELL \& ROBINSON, 1998, p. 4

${ }^{25}$ MITCHELL \& ROBINSON, 1998, p. 4.
} 
para o latim em 1815: De Danorum Rebus Gestis ${ }^{26}$. Este seu trabalho, apesar das imprecisões, foi muito importante para outros pesquisadores que o utilizaram em paralelo ao manuscrito; entre esses podemos citar N. S. F. Grundtvig, J. M. Kemble, Frederic Madden e Benjamin Thorpe.

Com relação ao documento Beowulf em especifico, devemos observá-lo com maior atenção com relação a suas características. Beowulf está dividido em seções numeradas chamadas fitts $^{27}$. Beowulf possui ao todo quarenta e três fitts, que se iniciam a partir do verso 52 (sendo estes versos iniciais um tipo de prólogo). Alguns estudiosos acreditam que os fitts teriam sido estipulados pelo autor; entretanto, existem aqueles que defendem a idéia de que tal divisão do poema teria sido obra daqueles que copiaram o poema (até mesmo os Escritores A e B) ${ }^{28}$. Embora esta divisão nem sempre ocorra em trechos onde, com um olhar moderno, se espera ocorrer uma pausa, temos elementos favoráveis a indicar que a divisão dos fitts não seria uma mera ocorrência mecânica de um copista. Por exemplo, dez dos fitts ${ }^{29}$ iniciam com a expressão maðelode, que indica a introdução de uma fala (por exemplo: Beowulf mapelode, bearn Ecgpeowes [Beowulf disse, o filho de Ecgtheow] vv. 1383), e três deles iniciam com o narrador em primeira pessoa com a expressão mine gefrcege ou ic gefrcegn ${ }^{30}$ ( gefrcege [Então foi pela manhã, eu ouvi] vv. 837).

Outro ponto importante a ser observado em relação ao manuscrito de Beowulf é sobre a organização dos documentos dentro do Cotton Vitellius A. XV. Vimos que além de Beowulf existem outros documentos. Como nós o conhecemos hoje, o manuscrito contém textos em prosa (documentos 1, 2 e 3) e em forma poética (4 e 5). É possível que está ordenação dos textos tenha se dado simplesmente devido à forma como os mesmos nos são apresentados. Humfrey Wanley em 1705 já nos relata que a disposição dos textos seguia esta mesma seqüência ${ }^{31}$. Entretanto, a posição original dos textos de São Cristóvão e Judite tem sido debatida, sendo levantada a hipótese de que devido a

\footnotetext{
${ }^{26}$ Para maiores informações acerca de Thorkelin e sua obra, ver LAPIDGE, pp. 446-7.

${ }^{27}$ Em inglês-antigo fitt significa "canção", "poema", e esta presente tanto na obras poéticas quanto em prosa do período anglo-saxão. No prefácio em latim do poema Heliand (composto em saxão-antigo) o termo é explicado como sendo uma seção, uma parte de um poema ou trecho adequado para uma leitura (lectio). Ver MITCHELL \& ROBINSON, 1998, p. 6.

${ }^{28}$ MITCHELL \& ROBINSON, 1998, p. 6-7.

${ }^{29}$ fitts VI, VII, VIII, XIIII, XX, XXI, XXII, XXIII, XXVI, XXVIII.

${ }^{30}$ fitts XIII, XXXVII, XXXVIII.

${ }^{31}$ ORCHARD, p. 23.
} 
elementos lingüísticos, Judite originalmente precedia a Paixão de São Cristovão ${ }^{32}$. Levando isso em consideração, poderíamos observar que ao alterar a ordem dos textos no manuscrito, teríamos o mesmo dividido em textos cristão (Judite, São Cristóvão), que estariam lidando com o passado do Velho Testamento e o período de conversão, com textos de um passado pré-cristão (Maravilhas do Oriente, Carta de Alexandre) e um texto cristão (Beowulf). Segundo essa teoria, certos elementos e características lingüísticas de estilo seriam muito semelhantes em Judite e na Paixão de São Cristóvão, enquanto os demais textos (inclusive Beowulf) teriam também suas próprias características em comum. Entretanto, um elemento que estabelece um vínculo mais forte entre os cinco documento talvez não esteja no campo lingüístico, mas sim no que se refere à natureza de seus personagens, ou melhor, à natureza das criaturas encontradas por suas personagens: os monstros.

Além de questões lingüísticas das variantes do inglês-antigo e da datação dos textos, a razão mais provável pelos cinco textos do Cotton Vitellius $A$. $X V$ terem sido guardados juntos seria devido às criaturas que fazem parte das narrativas, a similaridade temática entre eles. Desta forma, podemos dizer que nosso manuscrito em questão seria um “Livro de Monstros”33 (principalmente Maravilhas do Oriente, Carta de Alexandre e Beowulf). Assim como em Beowulf, as Maravilhas do Oriente nos descreve um mundo habitado por criaturas devoradoras de homens e dragões:

“Begeondan Brixonte pære ea, east ponon, beoð men acende lange ] micle, pa habbað fet ] sconcan .XII. fota lange, sidan mid breostum seofon fota lange. Hostes hy synd nemned. Cuðlice swa hwylcne man swa hy gelæccað, ponne fretað hi hyne. Đonne seodon wildeoar pa hatton Lertices. Hy habbað eoseles earan ] sceapes wulle ] fugeles fet. Donne syndon opere ealond suð from Brixonte on pon beoð (men) buton heafnum, pa habbað on hyra breostum heora eagan ] muð. Hy seondan eahta fota lange ] eahta fota brade. Đar beoð cende (dracan) pa beoð on lenge hundteontige fotmæla lange ] fiftiges, hy beoð greate swa stænene sweras micle. For para dracena micelnesse ne mæg nan man naypelice on pæt land gefaran.”

[Além do rio Brixontes, a leste daqui, existe um povo que nasce grande e alto, que tem pés e pernas de doze pés de comprimento, ombros com tórax de sete pés de

\footnotetext{
${ }^{32}$ ORCHARD, pp. 20-26: Segundo analise lingüísticas e paleográficas chegou-se à conclusão que o trabalho do Escritor A seria mais recente que a de B. Estima-se que o Escritor A tenha trabalhado no manuscrito no inicio do século XI, enquanto o Escritor B tenha trabalhado no final do século X.

${ }^{33}$ ORCHARD, p. 24.
} 
largura. Eles são negros, e são chamados de Hostes (“inimigos”). Assim que eles pegam uma pessoa eles a devoram. Assim existem no Brixontes animais selvagens que são chamados Letices. Eles têm orelhas de asno e pele de ovelha e pés de pássaro. Assim existe uma outra ilha, ao sul do Brixontes, na qual nascem homens sem cabeça que tem seus olhos e boca em seu peito. Eles têm oito pés de altura e oito pés de largura. Dragões nascem lá, e tem cento e cinqüenta pés de comprimento, e são tão grandes como pilares de pedra. Por causa dessa abundancia de dragões, ninguém pode viajar facilmente por essa terra.] (As Maravilhas do Oriente, seções 13-16)

Tais descrições de criaturas monstruosas e sua relação com os seres humanos nos fazem lembrar justamente as criaturas em Beowulf, onde a resposta para as ameaças de tais seres é justamente o confronto e extermínio do monstro. Podemos, por exemplo, comparar o trecho onde nos é descrito os olhos de Grendel, com os dos habitantes de uma ilha e com os olhos de uma serpente de duas cabeças:

"ligge gelicost leoht unfæger"

[semelhantes a chamas, luz abominável] (Beowulf, v. 727)

"scinap swa leohte swa man micel blacern onæle peostre nihte"

[brilham como luzes como se alguém tivesse acendido uma grande lâmpada na noite escura] (As Maravilhas do Oriente, seção 3)

“scinað nihtes swa leohte swa blæcern”

[brilham à noite, tão brilhantes quanto lâmpadas] (As Maravilhas do Oriente, seção 5)

Outra imagem interessante é a de Alexandre o Grande como o matador de monstros (o que já nos faz relacioná-lo com A Carta de Alexandre a Aristóteles), e seu interesse nas criaturas chamadas healfhundingas ${ }^{34}$ (Maravilhas do Oriente, seção 7; Carta de Alexandre, seção 29). Assim, a união dos três textos que claramente falam a respeito de criaturas monstruosas seria um indício do manuscrito ser uma coletânea de relatos fantásticos sobre seres monstruosos e figuras heróicas ${ }^{35}$.

\footnotetext{
${ }^{34}$ Criaturas com corpo de homens e cabeças de cães.

${ }^{35}$ ORCHARD, p. 25.
} 
Com relação à Carta de Alexandre a Aristóteles, existem mais similaridades com Beowulf, principalmente no que se refere ao aspecto heróico e guerreiro das personagens:

“Ond efne swiðe pa mine pegnas ] eal min weorod wæs gewelgod pæt hie uneðe ealle pa byrðene pæs goldes mid him aberan ] alædan meahton. Swelce eac heora wæpena noht lytel byrðen wæs for ðon eal heora wæpenu pæra mintra pegna ] ealles mines weoredes ] heriges ic (het) hie mid gyldenum pelum bewyrcean. Ond eall min weorod wæs on pa gelicnesse tungles oððe ligite for pære micelnisse pæs goldes. Hit scan ] berhte foran swa ymb me uton mid prymme ] herebeacen ] segnas beforan me læddon. Ond swa micel wundor ] wæfersien wæs pæs mines weoredes on fægernisse ofer ealle opre peodkyningas pe in middangearde wæron. Đa sceawede ic seolfa ] geseah mine gesælinesse ] min wuldor ] pa fromnisse minre iuguðe ] gesælignisse mines lifes, pa wæs ic hwæthwugo in gefean in minum mode ahafen.”

[E realmente, meus thegns (guerreiros) e toda minha tropa ganhou tantas riquezas que eles podiam com dificuldade trazer e carregar com eles o fardo de todo aquele ouro. Suas armas também não eram um fardo pequeno porque eu havia ordenado que todas as armas de meus thegns e toda minha tropa e exercito usassem armaduras de ouro. E toda minha tropa se parecia com estrelas ou relâmpagos devido a quantidade de ouro. Brilhavam e reluziam a minha frente e a meu redor em glória, e eles levavam a minha frente bandeiras de guerra e estandartes. E tão grandiosa era a visão e o espetáculo daquela minha tropa que o esplendor estava além de todos os outros poderosos reis que haveriam no mundo. Quando eu mesmo vislumbrei e vi minha prosperidade e minha glória e o sucesso de minha juventude e a prosperidade de minha vida, eu estava de certa forma realizado com prazer em meu coração.] (A Carta de Alexandre para Aristóteles, seção 11)

Este trecho da Carta de Alexandre pode ser comparado a Beowulf justamente no que diz respeito às imagens da tropa, da exaltação da figura heróica de Alexandre não apenas dentro da narrativa, mas também como uma figura ímpar mesmo entre outros governantes, das riquezas entregues aos seus soldados. Imagens muito semelhantes (se não idênticas) aparecem em Beowulf desde o começo. No poema, ao invés de Alexandre e seu exército temos o jovem Beowulf (cujo nome é famoso por todo o mundo) e seu bando-guerreiro que retornam para a corte do rei Hygelac cheios de tesouros que lhes 
foram presenteados pelo rei Hrothgar devido a morte do monstro Grendel e sua mãe. Na verdade, estas características estão presentes não apenas nestes textos, mas em toda a poesia heróica anglo-saxônica. Entretanto, além de mera semelhança de estilo, podemos estabelecer outros paralelos entre estes documentos.

No poema, Beowulf e seus guerreiros vão até o pântano, o lago onde seria o covil de Grendel e sua mãe; um local em meio de um ambiente hostil, mas ainda assim não muito distante de Heorot (o grande salão do rei Hrothgar). Este é um local cercado por árvores e despenhadeiros (Beowulf, vv. 1408-1417). Na Carta de Alexandre, Alexandre e seus homens cruzam um rio numa região mais inóspita, com as mesmas características que a morada dos monstros de Beowulf (Carta de Alexandre para Aristóteles, seção 12). Entretanto, as semelhanças não param por ai. Em outro momento na Carta de Alexandre, é descrito um episódio onde Alexandre e seus homens, ao tentarem atravessar um rio apara chegarem até um certo vilarejo são atacados por "monstros da água”:

"Pa het ic .CC. minra pegna of greca herige leohtum wæpnum hie gegyrwan, ] hie on sunde to pære byrig foron ] swumman ofer æfter pære ea to pæm eglande. ba hie ða hæfdon feorðan dæl pære ea geswummen, ða becom sum ongrislic wise on hie. pæs wæs ponne nicra mengeo on onsione maran ] umhyrlicran ponne ða elpendas in ðone grund pære ea ] betweoh ða yða pæs wæteres pa besencte ] mid heora muðe hie sliton ] blodgodon ] hie ealle swa foenamon, pæt ure nænig wiste hwær hiora æni cwom. Đa wæs ic swiðe yrre pæm minum ladpeowum, pa us on swylce frecennissa gelæddon. Het hiera ða bescufan in pa ea .L. ] .C. ] sona pæs ðe hie inne wæron, swa wæron pa nicoras gearwe tobrudon hie swa hie pa oðre ar dydon, ] swa picce hie in pære ea aweollon swa æmettan ða nicras, ] swilc unrim heora wæs. pa het ic blawan mine byman ] pa fyrd faran“.

[Então eu ordenei a duzentos de meus thegns do exército grego a se armarem com armas leves e atravessarem até a vila nadando, e eles nadaram através do rio até a ilha. E quando eles haviam nadado em torno de um quarto do rio, algo terrível lhes aconteceu. Lá surgiu uma multidão de monstros-da-água, maiores e mais terríveis na aparência do que elefantes, os quais tragaram os homens em meio às ondas para o fundo do rio, e os despedaçaram com sanguinolência com suas bocas, e dilaceraram a todos de modo que nenhum de nós sabia onde eles haviam ido parar. Então eu estava furioso com meus guias, que nos haviam guiado para tal perigo. Eu ordenei que cento e cinqüenta 
deles fossem empurrados para o rio, e assim que eles estavam na (água), os monstrosda-água estavam prontos, e os tragaram da mesma maneira como haviam feito com os outros, e os monstros-da-água se agitaram no rio tão numerosos como formigas, eles eram inúmeros. Então eu ordenei que fosse tocada a trombeta, e o exercito foi embora.] (Carta de Alexandre para Aristóteles, seção 15)

Esta idéia de criaturas que habitam as profundezas das águas e que devoram homens, também está presente em outras obras (como por exemplo, a Saga do rei Hrolf Kraki); entretanto, em Beowulf a imagem de ser capturado por monstros das profundezas ocorre por duas vezes. A primeira seria quando o herói Beowulf descreve seus feitos enquanto disputava com Breca uma competição de natação:

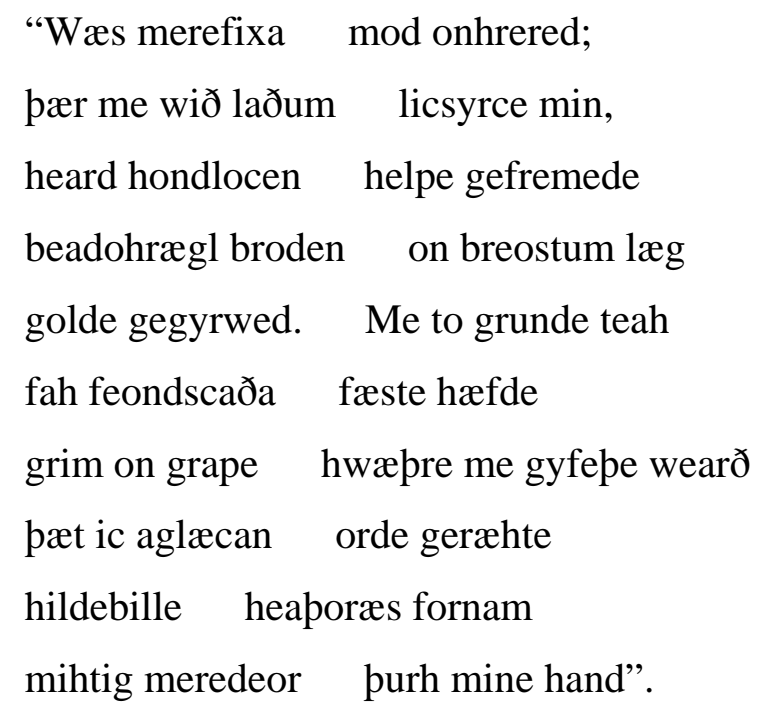

[Estavam os peixes-do-mar com os espíritos agitados, lá minha cota-de-malha, forte, feita a mão, me deu ajuda contra os inimigos, o equipamento de batalha pendia sobre meu peito, decorado em ouro. Um hostil e demoníaco atacante me puxou para o fundo, me mantendo preso em seu aperto; mas me permitido atingir o monstro com a ponta de minha arma, minha lamina de batalha; com intensidade da batalha destrui a poderosa besta-do-mar com minhas mãos] (Beowulf, vv. 549-558).

E a segunda passagem de um ataque ocorre quando ele (Beowulf) mergulha no lago onde vive Grendel e sua mãe:

$\begin{array}{ll}\text { “Grap pa togeanes } & \text { guðrinc gefeng } \\ \text { atolan clommum } & \text { no py ær in gescod }\end{array}$ 


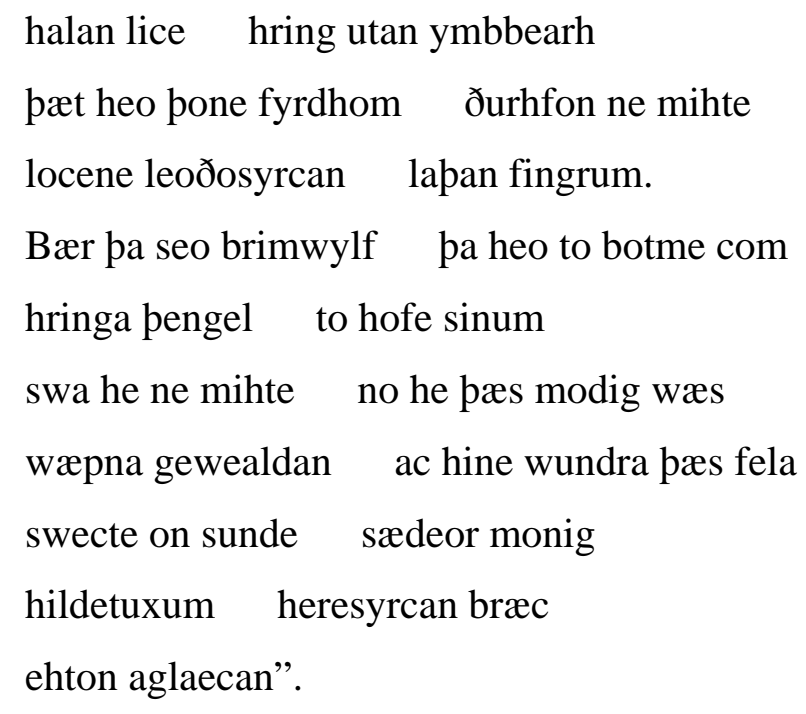

[Ele então o agarrou, capturou o guerreiro com suas terríveis garras; mas ainda ela não havia ferido seu corpo são; os anéis o haviam protegido, de forma que ela não pode penetrar a cota-de-malha, a armadura de batalha, com suas garras hostis. Quando ela chegou ao fundo o inimigo carregou o príncipe de anéis para seu lar, de forma que ele não podia, apesar de ser bravo, empunhar armas, mas uma hoste de estranhas criaturas o atacou no caminho, muitas feras do mar atingiram sua armadura com suas presas de batalha, garras de guerra, o atormentando com horrores] (Beowulf, vv. 15021512).

A partir dessas passagens, é possível notarmos certas similaridades temáticas entre os dois textos. Tais semelhanças podem ser ainda mais claras quando vemos na Carta de Alexandre, que mais tarde, após o episódio das criaturas do rio, Alexandre e seus homens acabam chegando num local onde se encontra um "certo lago muito grande” (sumne swiðe micelne mere), que é infestado por serpentes e répteis de toda espécie (seções 16-18); e mais tarde (seção 27) eles acabam por se defrontar uma criatura, um monstro, um habitante dos pântanos, exatamente como Grendel:

“Đa cwon pær semninga sum deor of pæm fenne ] of ðæm fæstene”

[Então veio de lá de repente uma fera dos alagadiços e dos charcos]

(Carta de Alexandre para Aristóteles, seção 15) 
mære mearcstapa, se pe moras heold

fen ond fæsten”

[este espírito detestável se chamava Grendel, conhecido andarilho dos ermos, guardião dos pântanos, alagadiços e charcos] (Beowulf, vv. 101-104).

Como podemos ver, a temática e as imagens utilizadas nos dois textos são muito parecidas. Isso poderia ser explicado pela suposição de que o autor da Carta de Alexandre já conhecia o poema Beowulf, e conscientemente (ou propositalmente) moldou seu trabalho de forma a utilizar aspectos do poema em sua obra; ou ainda, que ambos teriam sido elaborados dentro de um mesmo período, o que também justificaria tais semelhanças. Tal possibilidade torna-se interessante se levarmos em consideração a teoria de Janet Bately, de que a Carta de Alexandre teria sido composta no século IX ou inicio do século X. Assim, se a Carta de Alexandre e Beowulf estavam de alguma forma ligados antes de sua associação com as Maravilhas do Oriente dentro do Cotton Vittelius $A$. $X V$, então poderíamos pensar que não poderia haver um vinculo entre os dois textos antes do século $\mathrm{X}^{36}$. Como veremos mais adiante, boa parte do corpo poético que sobreviveu até a atualidade pertence justamente a esse período entre os séculos IX, X e XI. Desta forma, faria sentido a teoria de Bately e também reforçaria o debate pela datação mais tardia de Beowulf, a partir do século $\mathrm{X}^{37}$.

De qualquer forma, podemos observar pelos paralelos realizados entre os textos do Cotton Vittelius A. XV que há uma similaridade temática, não apenas dos monstros, mas também referente ao aspecto heróico que podemos identificar em todos os cinco textos. É provável que a organização do manuscrito tenha seguido sim uma ordem certa, que a seqüência de seus textos tenha sido intencionalmente posta como a conhecemos e que não tenha ocorrido erro algum dos Escritores A e B. Porque, independente da forma adotada pelos autores (prosa ou poesia), há certa ordem, senão vejamos: o manuscrito inicia com um texto em prosa hagiográfico (ou seja, uma narrativa de cunho cristão); segue com dois textos que tratam de relatos da antiguidade (logo pré-cristãos), mas que são muito semelhantes em sua temática e estilo (com os arquétipos de enfretamentos de

\footnotetext{
${ }^{36}$ ORCHARD, p. 35

${ }^{37} \mathrm{O}$ corpo poético anglo-saxão é formado por quatro grandes códices, que segundo Niel R. Ker seriam datados da seguinte forma (com uma aproximação de uns 25 anos para mais ou para menos): $O$ Livro de Exeter (c. 975), Codex Junius XI (c. 1000), O Livro Vercelli (c. 975) e o Cotton Vitellius A XV (c. 1000). Ver KER, pp. 15-20.
} 
monstros e a figura heróica de Alexandre, o Grande); na seqüência temos justamente o relato no mesmo estilo dos dois anteriores, mas agora tendo como cenário e personagens figuras também do passado, mas do mundo germânico cristianizado; e finalizando com outro poema, dessa vez também relatando um passado ainda mais distante (do Velho Testamento; logo também cristão), mas que é ao mesmo tempo heróico, ao estilo do próprio Beowulf. Ou seja, é uma seqüência de relatos que segue cada vez mais ao passado. Assim, apesar de parecer um pouco confuso para o leitor moderno, há de certa forma uma ordenação coerente no Cotton Vittelius $A$. $X V$, também conhecido como o Nowell Codex, ou simplesmente conhecido como o manuscrito de Beowulf. E é justamente o texto que dá nome ao manuscrito, que intriga seus pesquisadores há séculos (desde que Thorkelin o publicou pela primeira vez no século XIX), e que, ironicamente, ao tentar ser desvendado, se tornou também um “monstro" para seus estudiosos: o poema Beowulf. 


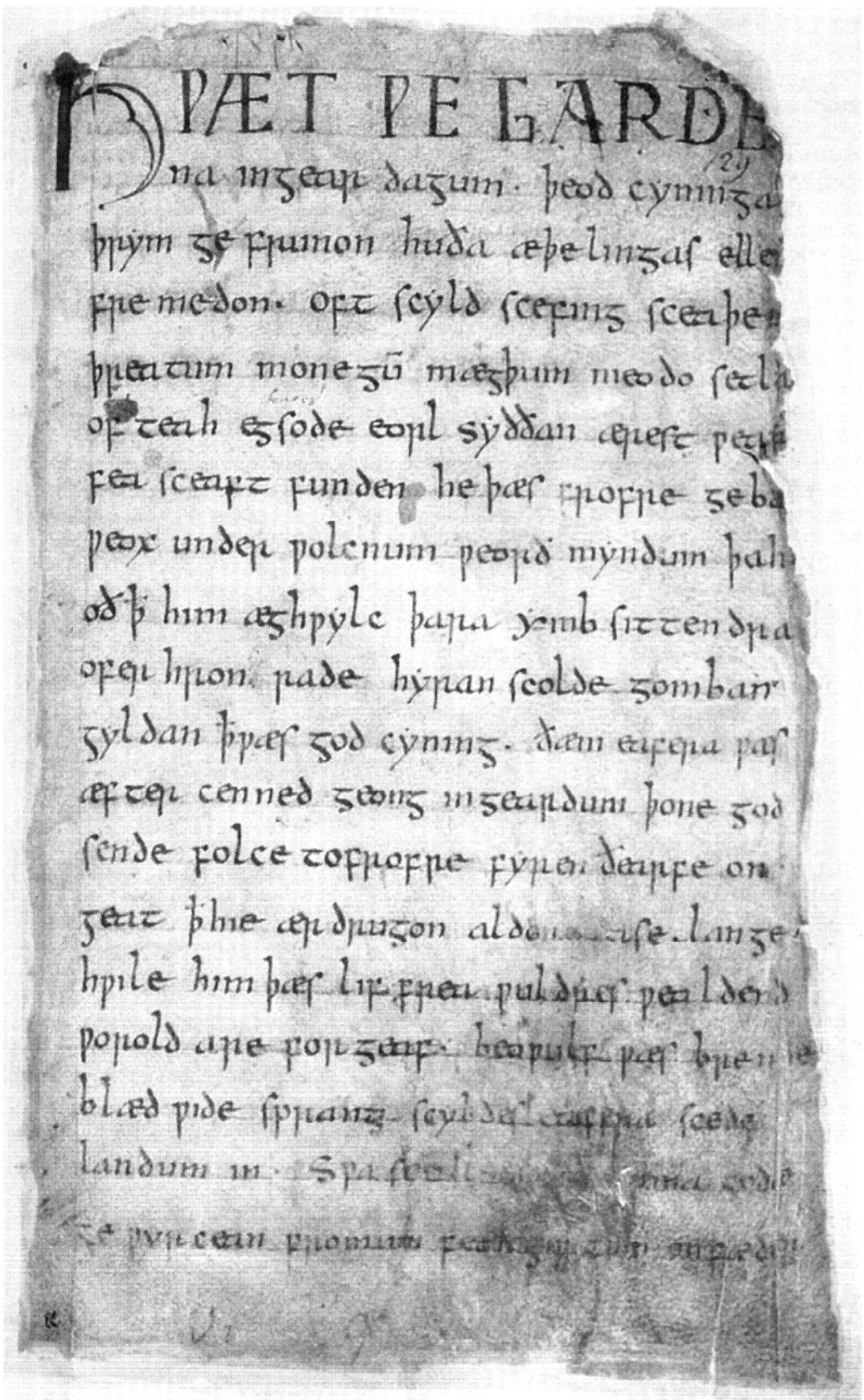

Figura 1: Cotton Vitellius A. XV, manuscrito de Beowulf, fol. 129r (Beowulf versos 1-21) [Andy Orchard, A Critical Companion to Beowulf,Cambridge: D.S.Brewer, 2004, p. 13] 


\section{I.2 - O Monstro}

O poema Beowulf é uma grande quimera. Ele possui elementos de várias origens que compõe sua temática, seu estilo é cronologicamente impreciso, sua estrutura do idioma possui variações lingüísticas de diversas partes da Inglaterra, possui influências pagãs e cristãs, entre outras coisas; ou seja, ele é um enigma. Esta pode parecer uma afirmação precipitada ou até mesmo radical, mas por fim talvez seja uma das poucas considerações que possamos fazer com total convicção a respeito do mais conhecido texto do Cotton Vitellius A. XV: Beowulf é uma quimera.

Dentro dos estudos sobre o período da Inglaterra Anglo-Saxônica, Beowulf talvez seja um dos documentos mais estudados, tanto em seu aspecto histórico quanto literário. Entretanto, muitos dos problemas e discussões em torno de Beowulf são na verdade criações dos próprios estudiosos do poema ${ }^{38}$ :

"Personally, I think that most of the difficulties in relation to the main theme of the poem are the creation of scholars, who look in the poem for certain features that are clear in this or that analogue, and then blame the poet for obscuring them if they fail to discover them"39

Isso apenas serve para reforçar nossa opinião de que ele seja uma quimera, um monstro para os pesquisadores, ou assim eles o fazem ser. Não podemos acreditar que todas as alegorias e imagens em Beowulf são frutos de meras apropriações (um texto de origem pagão com um “verniz” de cristianismo, por exemplo), ou que o autor seria tão "simplista” a esse ponto. Na verdade talvez o poema seja na verdade fruto de sua época. As teorias de que o poema tenha sido composto com algum tipo de propósito específico, ou a partir de outras obras (sofrendo assim uma simples adaptação, o que nos remete novamente ao problema do "verniz”) sejam errôneas; por isso nossa intenção é demonstrar Beowulf como um efeito decorrente de sua época e os elementos que poderiam levar para o surgimento de uma obra como essa e sua importância. Importância essa que por vezes é deixada de lado em prol de problematizações que não existem no documento, mas apenas dentro das conjecturas de alguns estudiosos da área.

\footnotetext{
${ }^{38}$ WHITELOCK, 1964, pp. 67-70.

${ }^{39}$ WHITELOCK, 1964. p. 67: "Pessoalmente, eu penso que as muitas das dificuldades em relação ao tema principal do poema são criações dos estudiosos, que procuram no poema por certa característica que seja clara nesta ou naquela analogia, e então culpam o poeta por obscurecê-las se eles falham ao descobri-las”.
} 
Em muitos trabalhos tenta-se analisar Beowulf de forma esquemática e didática. Entretanto, esta é uma tentativa equivocada de fazê-lo; devemos ter em mente o autor e a platéia da época que não tinham o poema como objeto de estudo, e nem faziam teorias sobre ele (mito versus história, alegorias cristãs e pagãs, influências e etc.). Para eles, os fatos narrados no poema eram interpretados como eles eram, sem distinções factuais ou históricas; os ouvintes acreditavam no que o poema lhes trazia ${ }^{40}$.

Ao iniciar um estudo sobre Beowulf, existem quatro elementos primordiais: origem, público, data e autoria. Dentre eles, a autoria é a de discussão mais árida uma vez que não importa o quanto se debata a respeito, não há como saber com certeza quem teria sido o responsável pela obra. Não existem elementos suficientes para que sustente qualquer tipo de teoria. Existem as mais diversas opiniões a respeito: de que o autor seria um poeta cristão com grande conhecimento das lendas germânicas, ou então um pagão recém cristianizado, ou um clérigo; ou ainda que teria sido não um, mas diversos autores $^{41}$. Portanto não é nossa intenção nos estendermos sobre tal assunto. Mas se a busca por sua autoria pode ser infrutífera, debates sobre sua datação, local de origem e público são bem mais acalorados.

Com relação a seu público, da mesma forma como a questão da autoria do poema, não há uma teoria conclusiva sobre o assunto. Entretanto, através da leitura do documento, podemos concluir certos pontos importantes, que nos poderiam auxiliar para pensar sobre seu local de origem e datação e talvez até mesmo a forma e estrutura da narrativa. Uma das idéias iniciais sobre Beowulf (e que ainda reluta em desaparecer por completo), seria de que o poema seria fruto de uma tradição germânica pré-cristã e que teria passado por uma adaptação, recebendo assim uma superfície de cristianização. Uma das bases para essa argumentação seria justamente o fato de que durante a narrativa a presença do cristianismo se faz de forma tímida; em nenhum momento é citada claramente a figura de Cristo ou de qualquer outro elemento cristão a não ser Deus. Isto não apenas tornaria Beowulf uma mera adaptação como faria do(s) autor(es) um ser de pouca criatividade. Entretanto, se analisarmos com mais cautela, poderemos perceber que existe algo mais em Beowulf que simplesmente uma narrativa pagã reaproveitada pelo cristianismo. Na verdade, existem mais elementos cristãos no poema do que a teoria da origem pagã quer ver.

\footnotetext{
${ }^{40}$ WHITELOCK, 1964, pp. 71-72.

${ }^{41}$ BJORK, \& OBERMEIER, 1998, pp. 28-31.
} 
A presença de elementos cristãos em Beowulf é uma parte fundamental do poema. Na verdade, não importa sabermos de uma suposta versão pagã anterior, pois não há provas disso, o mesmo não existe. O que temos é o manuscrito do Cotton Vittelius A. $X V$, e nele as imagens cristãs permeiam o texto, sendo parte dele de forma intrínseca, fruto de um autor (ou autores) que sabia o que estava fazendo ${ }^{42}$. Segundo Whitelock $^{43}$, o público de Beowulf era cristão (ainda que germanizado, mas mesmo assim cristão), pois os termos e as referências bíblicas são breves e pouco esclarecedores para um publico que não tivesse conhecimento da doutrina cristã. Caso contrário, os ouvintes do poema não iriam compreender as passagens sobre a linhagem de Caim e o Dilúvio, por exemplo. Além disso, a presença de imagens do Velho Testamento pode reforçar essa visão de uma platéia cristã, não só para Beowulf, como também para todo o corpo poético anglo-saxão:

"Any set of persons in Anglo-Saxon times that is well-informed on the Old Testament can be assumed to be cognizant of the Christian faith as a whole”44.

Ou seja, durante a conversão, eles deveriam aprender sobre os Evangelhos, a redenção do mundo através da Paixão de Cristo, e só mais tarde sobre o Velho Testamento. Assim, se estavam sendo utilizado figuras do Velho Testamento seria porque seus ouvintes já teriam conhecimento, ainda que superficial, de toda a doutrina cristã. A presença dos monstros no poema, por exemplo, teria a função também de reforçar o aspecto cristão da narrativa; ao relatar a linhagem de Grendel, fica clara a referência de que ele não existia antes da Criação e que é fruto do pecado de Caim ${ }^{45}$. Entretanto, em seu artigo de 1936, Tolkien alega que o trecho do poema dos versos 175188 teriam sido introduzidos posteriormente e de forma muito "artificial”, segundo $\mathrm{ele}^{46}$ :

\footnotetext{
${ }^{42}$ Esta idéia foi defendida por dois grandes especialistas nos estudos sobre o poema: J. R. R. Tolkien (TOLKIEN, 1997, p. 23) e Dorothy Whitelock (WHITELOCK, 1964, pp. 3-4), entre outros pesquisadores mais recentes; ver BJORK, \& OBERMEIER, 1998, pp. 31-33.

${ }^{43}$ WHITELOCK, 1964, pp. 5-6.

${ }^{44}$ WHITELOCK, 1964, p. 7: "Qualquer grupo de pessoas nos tempos anglo-saxônicos que é bem informada a respeito do Velho Testamento pode se considerar em ser conhecedora da fé cristã como um todo."

${ }^{45}$ Em seu artigo de 1971, R. E. Kaske argumenta de uma possível influência não apenas do Velho Testamento, mas também apócrifa na composição de Beowulf, em especial do livro de Enoch (I Enoch). Entre os paralelos que ele estabelece, o mais interessante seria sobre a imagem de Grendel e da linhagem de Caim como sendo inspirada pela passagem do livro apócrifo a respeito da queda dos anjos e sua união com as "filhas dos homens", o que gerou uma raça de gigantes devoradores de homens amaldiçoados por Deus, exatamente a imagem de Grendel como nos é passada no poema. Ver KASKE, 1971, p. 421-431.

${ }^{46}$ TOLKIEN, 1997, pp.42-44.
} 


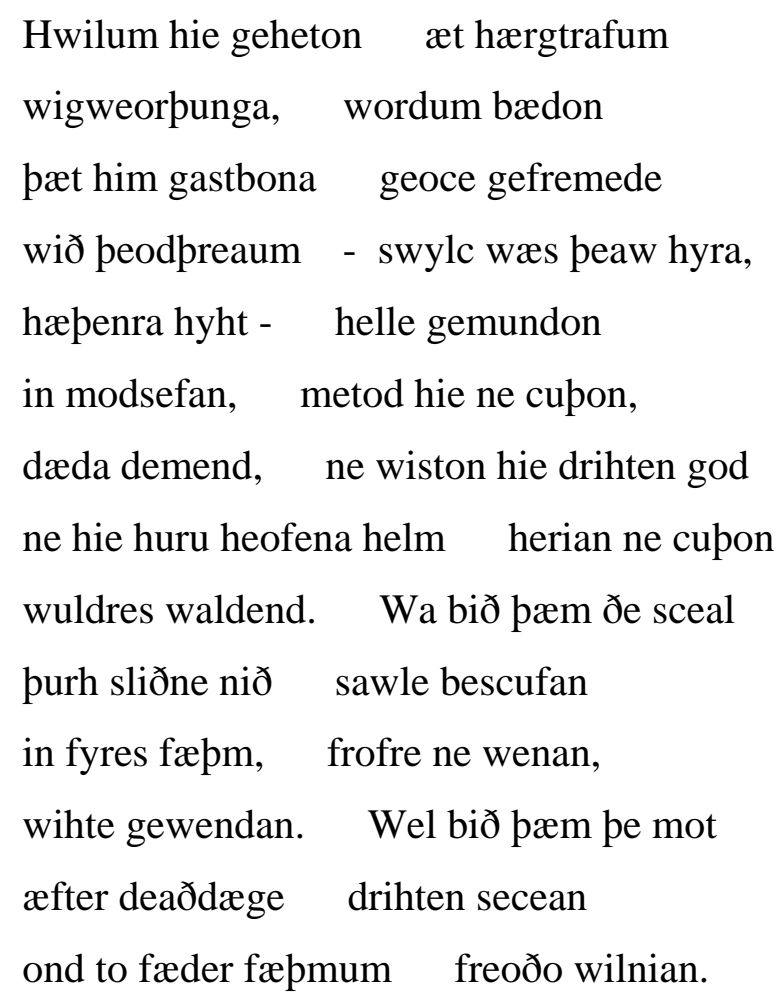

[Às vezes eles faziam pedidos em templos pagãos, adoravam ídolos, diziam preces para que o destruidor de almas os ajudasse contra essa calamidade - tal era o costume deles, a crença dos pagãos - mantinham a lembrança do inferno no interior de seus corações, eles desconheciam o Criador, o Juiz dos atos, eles não sabiam do Senhor Deus, nem mesmo sabiam reverenciar o Guardião celestial, o Regente glorioso. Infeliz deve ser aquele que durante grande aflição confia sua alma ao abraço do fogo, nenhum conforto de esperança de mudança terá realmente. Abençoado será aquele que puder após o dia de sua morte buscar o Senhor e ansiar por proteção no abraço do Pai.] (Beowulf, vv. 175-188)

Com esta alegação, Tolkien abriu margem para argumentações que reforçassem a idéia do poema ter sido adulterado de alguma forma, ter sido alterado se adequando mais ainda a um ambiente cristão. Não descartamos essa possibilidade; entretanto, talvez exista uma razão para esta passagem estar no poema, caso ela não tenha sido realmente enxertada no texto. Ao final dessa passagem, podemos encontrar uma máxima referente àqueles que seguem o Senhor e os pagãos. Podemos interpretar esta passagem de forma que tal trecho seja o reflexo de fatos presentes na sociedade da época referente a possíveis reminiscências e "renascimentos" de práticas pagãs na Inglaterra. Para tal, podemos ver as leis dos reis saxões, principalmente durante a Era 
Viking devido às práticas pagãs dos escandinavos; ou ainda temos o exemplo do sínodo de Clovesho em 747, quando ocorre uma repressão às ditas práticas pagãs (entre elas a proibição de se usar um chifre como cálice na celebração das missas) ${ }^{47}$; ou ainda, a carta de Alcuíno de York a Lindisfarne, onde ele critica os monges pelo seu interesse pelas antigas lendas heróicas ${ }^{48}$. Com isso chegamos a outro ponto importante, que é a função modelar do poema em relação a seu público.

Uma das hipóteses com a qual lidamos é a de que Beowulf seguiria um padrão das sagas germânicas no que diz respeito a seu público e função. Ou seja, trata-se de uma narrativa de cunho aristocrático: personagens membros de uma aristocracia guerreira, e que são apresentados justamente para uma platéia do mesmo âmbito social. Entretanto, há também o elemento cristão, que não está presente nas demais sagas germânicas, ao estilo das narrativas escandinavas, mas que está presente dentro do corpo poético anglo-saxão e no continente também. Enquanto na Inglaterra temos Beowulf, Judite ou ainda as versões em inglês antigo do Gênesis, Exodus e Daniel, no continente nós vamos ter o poema Heliand. Essas obras combinam as características das sagas germânicas com a imagem modelar cristã; ocorre uma adaptação de temas bíblicos ao cotidiano e à sociedade germânica. É claro que esse fenômeno não é exclusivo da Inglaterra anglo-saxônica, como nos mostra Erich Auberbach:

“Num fragmento de uma peça pascal francesa de começos do século XIII (...) em que o tema tratado é o das cenas entre José de Arimatéia e o cego Longino, curado pelo sangue de Cristo, os soldados de Pilatos são chamados chivalers ou apostrofados de vaissal, e todo o tom da conversa entre as personagens, por exemplo, entre Pilatos e José, ou entre José e Nicodemo é, de uma maneira totalmente evidente e emocionante, o tom da conversa da França do século XIII”49.

E o um dos pontos principais dessas narrativas heróicos e modelares, é que elas sempre remetem a um passado distante e ideal, mas que ao mesmo tempo reflete a realidade do presente: em nosso caso, o mundo aristocrático germânico de Beowulf, ou ainda, como um paralelo adequado, o mundo cavalheiresco da Canção de Rolando ${ }^{50}$. Assim, o que temos é uma narrativa aristocrática, de perfil aristocrático e modelar dentro de uma sociedade germânica. Como outro exemplo de seu aspecto modelar, em Beowulf ainda temos as máximas. Existem pouco mais que vinte máximas por todo o

\footnotetext{
${ }^{47}$ WHITELOCK, 1964, pp. 78-79.

${ }^{48}$ Monumenta. Germaniae. Historica. Epistolae IV, epist. 124.

49 AUERBACH, p. 140.

${ }^{50}$ AUERBACH, pp. 104-105.
} 
poema, que servem como exemplo a sociedade para a qual o poema se dirige, ${ }^{51}$ servindo como um código de conduta:

“O instante cênico, com os seus gestos, contém tanto ímpeto que tem o efeito de um modelo moral. Os diferentes estágios da história do herói ou do traidor ou do santo são concretizados em gestos em tal medida que as cenas plásticas se aproximam muito, no seu efeito, do caráter de símbolos ou figuras, também nos casos em que não é comprovável qualquer significação simbólica ou figural”52.

Como podemos observar, a composição de uma obra como Beowulf tem seu papel dentro de uma sociedade como era a Inglaterra anglo-saxônica, uma narrativa que, além de obviamente servir como entretenimento, era também exemplar dentro do círculo social no qual ela se direcionava. Círculo este que abrangia não apenas uma aristocracia laica, mas também encontrava espaço dentro da Igreja, uma vez que tínhamos na Inglaterra (ao menos até a reforma no século XI) uma Eigenkirche ou Adelskirche, uma Igreja da nobreza ${ }^{53}$.

Podemos ver que mais importante para os estudos a cerca de Beowulf em saber sobre sua autoria, é ter conhecimento de seu público alvo. O poema, desta forma, não seria uma obra direcionada para toda a população, mas sim especificamente para um grupo social. Para alicerçar isso, vemos que nesse tipo de narrativa o heróico, o sublime, está separado do cotidiano prático ${ }^{54}$. Tais textos não tratam da vida comum e simples, mas sim do ideal de uma sociedade guiada por lof (glória) e dom (honra). Este é um aspecto importante a ser observado. Tolkien já havia tratado da importância desses dois aspectos no mundo germânico ${ }^{55}$, que teriam suas origens em tempos pagãos e que persistem, mas se adequando ao cristianismo: lof passa a estar relacionado às idéias da presença no Céu e dos anjos, enquanto dom passa a ter a idéia de mérito no julgamento de Deus. Mas ainda assim, seus sentidos originais não se perdem, o sentimento da glória atingida por seus feitos acaba por trazer grande renome; como ocorre ao final de Beowulf nos versos 3175-3182:

\footnotetext{
${ }^{51}$ Estas máximas serão abordadas de forma mais aprofundada no Capitulo III.

${ }^{52}$ AUERBACH, p. 100.

${ }^{53}$ FLETCHER, 1999, pp. 154-155.

${ }^{54}$ AUERBACH, p. 105.

55 TOLKIEN, 1997, pp.36-42.
} 


\begin{abstract}
“wyruldcyning
manna mildust monðwærust

leodum líðost ond lofgeornost”.
\end{abstract}

[dos reis deste mundo, ele foi o mais benevolente e o mais gentil, bondoso com o povo, e o que mais deseja por gloria $]^{56}$

É interessante vermos que tal idéia está presente também nas palavras do rei Alfred, o Grande em sua versão de Boethius:

"Eu desejo viver honradamente tanto quanto eu viva, e deixar de minha vida para os homens que deverão vir depois de mim minha memória em boas obras”57.

Portanto, vemos que a busca pela glória e pela honra, o reconhecimento de seu valor é algo presente dentro desta sociedade, sendo assim refletida em sua produção literária. E uma vez que temos essas características em mente, podemos realizar uma possível localização temporal deste tipo de manifestação cultural.

Da mesma forma como outros aspectos de Beowulf, uma localização no tempo e espaço é complexa. Não se tem ao certo um local ou momento específico onde possamos afirmar como origem do poema. Em relação à metodologia adotada para se definir a origem de Beowulf, Whitelock nos traz um bom argumento: não basta que nossa hipótese se encaixe bem num dado momento histórico, é preciso saber se o mesmo não se encaixaria em mais algum outro também ${ }^{58}$.

Dentre alguns caminhos seguidos no sentido de solucionar o problema da datação do poema, principalmente no campo literário, alguns optam por uma análise a respeito do idioma e do dialeto utilizado em sua composição. Entretanto este método é um tanto quanto dúbio ${ }^{59}$. A utilização de um certo dialeto na Inglaterra anglo-saxônica não significa que sua composição se deu no mesmo local de origem do mesmo. Além disso, a falta de documentação no dialeto de uma região não prova que nada foi lá

\footnotetext{
${ }^{56}$ Idéia semelhante também pode ser encontrada no Hávamál (parágrafo 76): “O gado morre, familiares morrem, eu mesmo irei morrer; mas o bom nome nunca morre para aquele que o mereceu”. Ver HOLLANDER, p. 25.

${ }^{57}$ WHITELOCK, 1964, p. 98.

${ }^{58}$ WHITELOCK, 1964, p. 28.

${ }^{59} \mathrm{O}$ dialeto utilizado na maior parte do texto de Beowulf é o inglês-antigo de Wessex, mas é possível encontrar indícios de dialetos de Anglia Oriental, Northumbria e Mercia. Logo, temos um amálgama de dialetos dentro do poema.
} 
composto; é possível que a predominância de documentos em outro dialeto (que não corresponderia ao daquela região) mostre que ele fosse um tipo de padrão a ser utilizado em tais obras ${ }^{60}$.

Outro aspecto seria procurar por referências e alusões externas ao poema. O que também não demonstrou grande sucesso. O herói Beowulf, assim como Grendel, não é citado em mais nenhum outro texto do período, a não ser algumas meras suposições, mas sem nada de concreto $^{61}$; diferente de outras fontes que são citadas em Beowulf, como a história dos Volsungs e a Batalha de Finnesbuhr.

Uma vez que tanto aspectos lingüísticos quanto referências em outras fontes não são suficientes para uma precisão mais adequada do local e data de composição do poema, nos resta buscar elementos históricos para nos auxiliar. Portanto, levantamos algumas condições iniciais que permitiria a nós a surgimento de hipóteses para a composição de tal obra:

a- Desenvolvimento intelectual e artístico.

b- Estabilidade política (o que descartaria o período dos ataques vikings).

c- Interesse pela temática do poema.

Desta forma, podemos chegar a cinco períodos mais propícios para o surgimento do poema Beowulf:

A.) Northumbria (dos tempos do Venerável Beda): período em que temos a “renascença northumbriana”, algo em torno do século VIII.

B.) Mercia (nos tempos do rei Offa, ou de seus descendentes Boernwulf e Wiglaf): além do poder da hegemonia de Mercia durante o século IX, há também as referências a personagens com os mesmos nomes que os governantes de Mercia.

C.) Anglia Oriental: devido ao sítio arqueológico de Sutton Hoo e a similaridade dos artefatos encontrados com os que são descritos no poema, além de indicações lingüísticas.

\footnotetext{
${ }^{60}$ WHITELOCK, 1964, pp. 30-31.

${ }^{61}$ WHITELOCK, 1964, pp. 66-67, 72-74.
} 
D.) Wessex (a partir do governo do rei Alfred, o Grande; final do século IX e X): é momento favorável para o desenvolvimento cultural e político. Momento da reconquista dos territórios dominados pelos escandinavos e surgimento, propriamente dito, de um reino da Inglaterra sob a hegemonia de Wessex.

E.) Governo de Æthelred II e Cnut, o Grande: devido aos conflitos (talvez os monstros do poema fossem um reflexo dos desastres do governo de Æthelred II), ou ainda devido à presença dos escandinavos novamente na Inglaterra (no governo de Cnut).

Apesar de todos esses cinco momentos terem suas razões, acreditamos que um deles tenha mais elementos que justificasse o surgimento de um poema como Beowulf; sendo este o período D.: Wessex. Dizemos isso porque além de elementos históricos favoráveis, haveria também todo um cenário propício que não apenas possibilitava como teria sido conduzido para o surgimento de todo um corpo poético de características heróicas e cristãs, onde Beowulf seria apenas mais um texto fruto desse momento. Os elementos favoráveis a Wessex poderiam ser definidos de forma geral em:

- Referência em documentos como a Crônica Anglo-Saxônica e a Crônica Fthelweard, onde encontramos nomes da ascendência da casa de Wessex que poderiam estar ligados aos personagens de Beowulf, referentes à linhagem dos reis dinamarqueses. Tais referências surgem exatamente no relato da morte do rei Æthelwulf, pai do rei Alfred.

- O período que os documentos abrangem é um momento fora dos grandes ataques vikings e crises. Um período de relativa ordem (como no governo do rei Edgar, que até diminuiu o contingente militar por ser desnecessário um grande exército uma vez que não havia mais tantos ataques). Um momento propício de relacionamento maior com as populações das terras da Danelaw, os escandinavos e seus descendentes.

- Período ideal para a ideologia heróica, uma vez que era um momento de reconquista dos territórios nas mãos dos escandinavos e de uma ascensão 
política de Wessex sobre as populações anglo-saxônicas e escandinavas; principalmente no século X, no governo do rei Athelstan.

Como podemos ver, existiam elementos favoráveis para termos uma obra poética e de cunho heróico como Beowulf surgindo exatamente nas regiões de Wessex entre o século IX e X. Entretanto, para que possamos compreender melhor como e porque isso teria ocorrido, devemos analisar mais detalhadamente o período em questão e em especial o que poderíamos chamar como período alfrediano, e as fontes que ligariam Beowulf com a casa de Wessex. 


\section{CAPÍTULO II - A Casa de Wessex}

"As mentes daqueles nas quais há interesse consciente em governar estão sempre em alerta”. Asser, Vida do Rei Alfred.

\section{II.1 - A presença escandinava na Inglaterra}

Em sua renomada obra, Anglo-Saxon England, publicada pela primeira vez em 1943, Sir Frank M. Stenton inicia o capítulo VIII com as seguintes palavras:

"At the end of the eighth century each of the three Scandinavian peoples of historic times formed a nation, with its own traditions and a clear sense of its difference from its neighbours. The Geatas, Beowulf's people, were now united with the Swedes; their name was remembered, but their dynasty had long since come to an end."62

Desde então, muitos elementos alteraram esta afirmação, por meio de diversos debates e trabalhos de diversos autores, sabemos que não se pode dizer com certeza se os geats citados no poema Beowulf seriam realmente suecos ou talvez uma outra denominação para os jutos ${ }^{63}$. Além do que, a chamada "geografia de Beowulf”, baseada nas idéias de Klaeber ${ }^{64}$, são hoje facilmente aceitas como uma realidade, porém não há nenhum estudo conclusivo que a comprove.

\footnotetext{
${ }^{62}$ STENTON, p. 239: "Ao final do século VIII cada um dos três povos escadinavos dos tempos históricos formavam uma nação, com suas próprias tradições e uma noção clara de suas diferenças com seus vizinhos. Os geatas, o povo de Beowulf, está agora unido aos suecos; seus nomes são lembrados, mas sua dinastia hámuito chegou a um fim”.

${ }^{63}$ Estudos mais aprofundados sobre esse tema podem ser encontrados em trabalhos como de MITCHELL, Bruce \& ROBINSON, Fred C. (ed. e org.) Beowulf, Oxford: Blackwell, 1998; CHASE, Collin. The Dating of Beowulf, Toronto: Toronto University Press, 1997; BJORK, Robert E. \& NILES, John D. A Beowulf Handbook, Lincoln: Nebraska University Press, 1998; ORCHARD, Andy. A Critical Companion to Beowulf, Cambridge: D.S.Brewer, 2004..

${ }^{64}$ Klaeber é responsável por uma das edições mais famosas do poema (KLAEBER, Frederick (ed.) Beowulf and the Fight at Finnsburg, Boston: D. C. Heath, 1950). A idéia que ele nos oferece seria localizar a tribo de Beowulf, os geats, no sul da Suécia atual; já a corte do rei Hrothgar estaria localizada na Dinamarca, mais especificamente na ilha de Zealand, onde se encontraria o grande salão Heorot. Entretanto, em nenhum momento a narrativa nos trás qualquer indicação geográfica precisa; vale lembrar que não podemos nos basear em divisões políticas modernas, visto que, por exemplo, por um longo período da Alta Idade Média a região da Dinamarca abrangia o que corresponde ao seu território atual e mais o extremo norte da Alemanha e o sul da Suécia.
} 


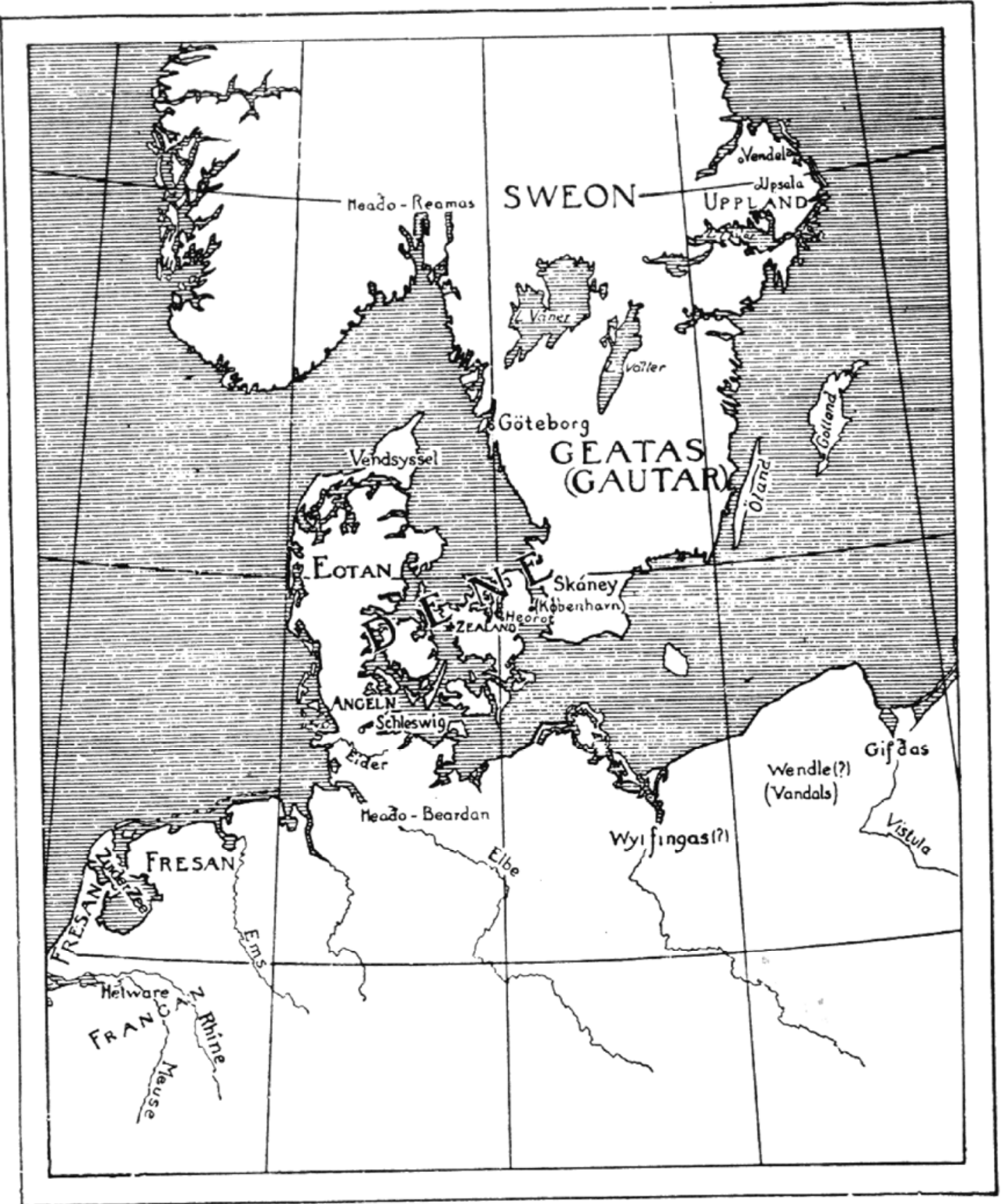

The Geography of Beowulf.

figura 2: Mapa elaborado por Klaeber, onde retrataria a susposta "geografia de Beowulf". [Frederick Klaeber (ed.) Beowulf and the Fight at Finnsburg, Boston: D. C. Heath, 1950, p. viii] 


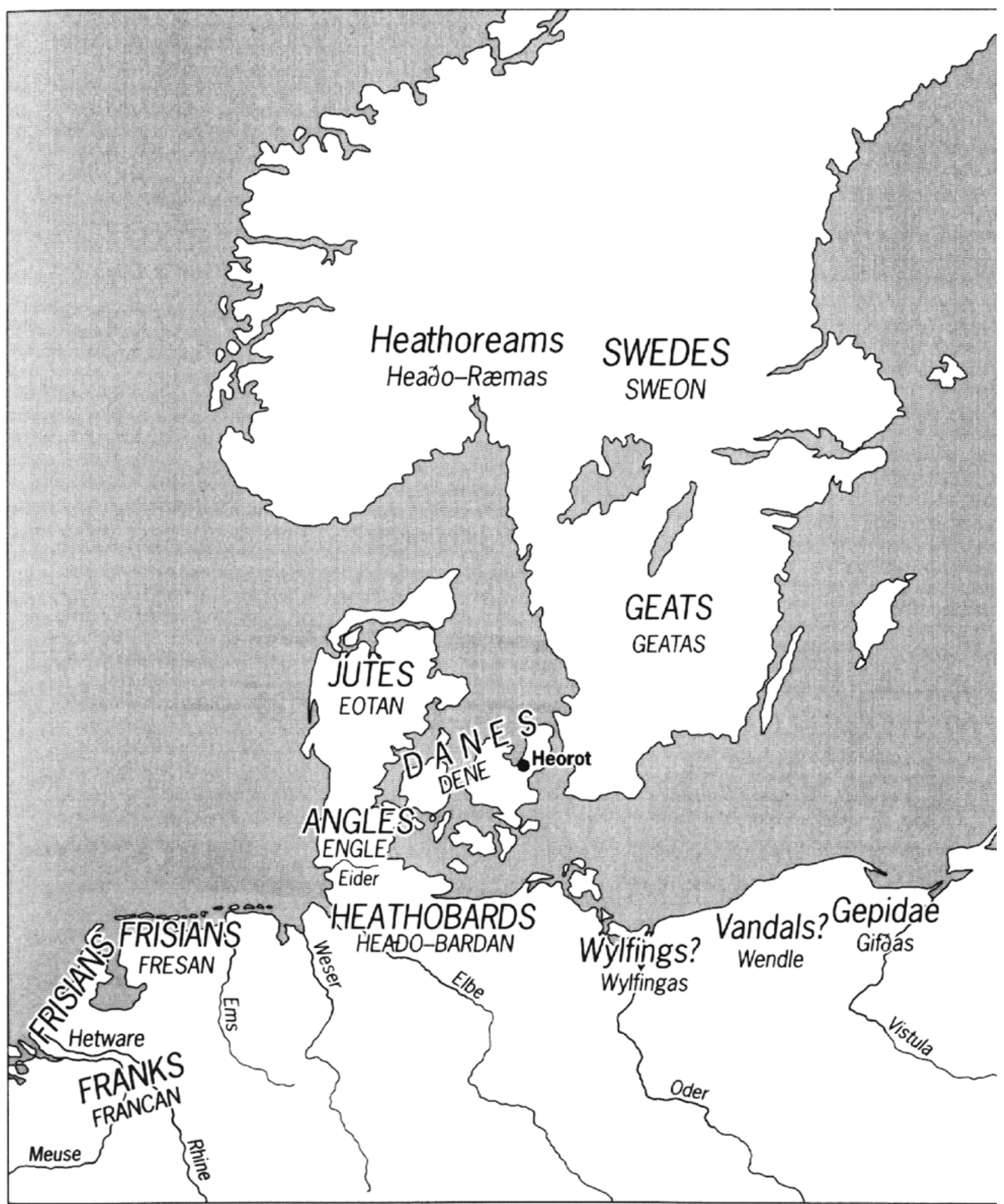

figura 3: Mapa baseado em Klaeber e atualizado a respeito da "geografia de Beowulf". [Bruce Mitchell \& Fred C. Robinson (ed. e org.) Beowulf, Oxford: Blackwell, 1998, p. xiii] 
Outro ponto a ser observado, é que as populações escandinavas não estariam assim tão bem organizadas como se poderia imaginar a partir das palavras de Stenton. Na verdade, até meados do século IX os vikings não possuíam grandes diferenças entre si. Viviam em pequenas comunidades lideradas por chefes-guerreiros, seguiam as mesmas leis e falavam a mesma língua (nórdico antigo). Com o tempo, devido a condições geográficas e políticas, acabaram se dividindo em três grupos, que, de forma geral, atuaram em diferentes regiões da Europa: os dinamarqueses, na Inglaterra e no continente; os noruegueses, norte da Inglaterra, Escócia, Irlanda e Mediterrâneo; e os suecos, no leste europeu e império bizantino.

Enquanto isso, durante este mesmo período, final do século VIII, a Inglaterra estava dividida em diversos reinos saxões que estavam constantemente lutando entre si: Wessex, Kent, Lindsey, Mercia, Northumbria, Anglia Oriental, entre outros. Os anglosaxões eram povos oriundos do norte da Europa continental; península da Jutlândia e noroeste da Alemanha que durante o século V migraram para antiga província romana da Britânia. Eles foram a princípio aceitos pelos bretões sob a condição de auxiliá-los contra a ameaça dos irlandeses e principalmente dos pictos, que viviam além da muralha de Adriano (atual Escócia). Esses povos, respectivamente os anglos, os saxões e os jutos, auxiliaram os bretões; mas assim que os pictos não eram mais um problema, eles mesmos se tornaram a ameaça. Passaram então a ocupar as regiões da Britânia, empurrando os bretões cada vez mais para o oeste, para Gales e Cornualha, tomando suas terras, até que tivessem conquistado toda a região. Fundaram novos reinos, sendo um dos primeiros o de Kent (fundado pelo lendário Hengest, o qual juntamente com o irmão, Horsa, enfrentaram o rei Vortigern ${ }^{65}$ ) e Wessex, fundado por Cerdic. A partir de então começa o período da chamada “Inglaterra anglo-saxônica”, se estendendo de 449 d.C., com as primeiras levas invasoras anglo-saxônicas, até 1066, com a morte de Harold Godwinson na batalha de Hasting. Entretanto, durante a segunda metade deste período, surge um outro momento diretamente ligado à história inglesa: a Era Viking, que será muito importante para a análise do contexto histórico de nosso estudo, que é justamente a ascensão da casa real de Wessex durante o século X.

Como os anglo-saxões haviam feito nos séculos V e VI, os escandinavos passaram a atacar a Inglaterra, até que no final do século VIII os ataques tornaram-se mais freqüentes. Um dos primeiros relatos é datado de 789 , ao sul da Inglaterra

\footnotetext{
${ }^{65}$ Assim como é relatado no ano de 449, segundo a Crônica Anglo-Saxônica. Ver WHITELOCK, 1961, p. 10.
} 
(provavelmente em Portland) quando um grupo de vikings havia chegado à costa, e um emissário do rei, acreditando serem mercadores, foi até eles para exigir que o acompanhasse até a presença de seu senhor; a resposta dos vikings foi exterminá-lo e saquear a região. Mas o mais famoso, sendo o que causou maior impacto, foi o ataque de 793 ao mosteiro de Lindisfarne, na costa da Northumbria, o qual se convencionou como o início da chamada “Era Viking”, que se estenderá até o século XI, com a batalha de Stamford Bridge, quando o último governante tipicamente viking (Harald Hardraði, rei da Noruega) morrerá em 1066. Os invasores saquearam e incendiaram o mosteiro, e os monges que não morreram provavelmente foram levados e vendidos como escravos. As notícias do ataque chocaram toda a cristandade da época. Alcuíno de York, que estava na corte de Carlos Magno, escreveu a Æthelred, rei da Northumbria: "Vêde, há quase trezentos e cinqüenta anos que nós e nossos antepassados vivemos nessa bela terra e nunca antes apareceu na Inglaterra horror como o que acabamos de sofrer dos pagãos (...) Olhai a igreja de São Cuthbert manchada com o sangue dos padres de Cristo, roubada de todos os seus ornamentos (...)”. ${ }^{66}$

Durante esse período iria se ouvir nas igrejas a oração que dizia: “A furore normannorum, libera nos, Domine". ${ }^{67}$

Os motivos para os ataques em geral são atribuídos às condições climáticas na Escandinávia que proporcionavam períodos de improdutividade e conseqüentemente fome e, combinado a isso, a falta de territórios cultiváveis. Os povos escandinavos do século VII e VIII possivelmente enfrentavam condições muito similares aos anglosaxões de duzentos anos antes. Ainda hoje este é um assunto muito debatido, mas acredita-se que a Escandinávia passava por um momento de fome e um aumento exagerado da população, sem esquecer que a geografia da região, composta por regiões de pântanos e montanhas, dificultava ainda mais a vida de seus habitantes. Desta forma, eles teriam sido impulsionados a buscar novas regiões, com melhores terras, onde pudessem prosperar. Apesar desta ser a teoria mais aceita entre os estudiosos do assunto, há uma contradição, pois os primeiros ataques dos vikings visavam apenas o saque e a pilhagem, só posteriormente é que iriam começar as ocupações. Também não são descartadas razões políticas e até mesmo o "espírito de aventura”68.

\footnotetext{
${ }^{66}$ WHITELOCK, 1955, p.775. Ver também Monumenta Germaniae Histórica, Epistolae IV, Epistola 129, p. 183.

67 "Oh Senhor, livrai-nos da ira dos homens do norte!"

${ }^{68}$ ROESDAHL, pp. 185-194; JONES, 1984, pp. 182-183; COHAT, pp. 12-19; SAWYER, 1997, pp. 1-8, 16-25.
} 
A Inglaterra foi a região que mais sofreu as investidas escandinavas, principalmente devido a sua posição geográfica. Entretanto, mesmo entre as regiões das Ilhas Britânicas, a Inglaterra sempre foi a mais visada pelos vikings. Uma das razões seria a prosperidade inglesa sobre as demais partes das ilhas, proporcionada principalmente pelo período de dominação romana. Como província romana a Inglaterra passou por uma organização, e o mais importe para seu futuro desenvolvimento, uma produção monetária.

Desde os tempos romanos a Inglaterra manteve uma produção de moedas e um sistema monetário organizado. Na verdade, por volta de 326 d.C. a cunhagem de novas moedas foi paralisada, sendo retomada em sua totalidade apenas na segunda metade do século VIII ${ }^{69}$. Mesmo assim a Inglaterra era a região mais rica das ilhas. Nas demais regiões que se mantiveram não romanizadas, não havia nenhum tipo de sistema monetário, sendo o comércio basicamente ainda na forma de trocas.

Não foram as moedas em si que atraíram os vikings, mas devido a um sistema monetário era possível um melhor desenvolvimento da região, e justamente por possuir este avanço sobre seus vizinhos de origem céltica é que a Inglaterra passou a ser mais procurada. Afinal, as maiores fontes de produções e riquezas estavam na antiga província romana.

Já nos tempos das primeiras invasões, a Inglaterra mantinha comunicações com outras regiões da Europa, principalmente com o reino dos francos. Mas com as invasões isso acabou se expandindo, surgindo uma maior comunicação entre as regiões banhadas pelo Mar do Norte. É justamente neste período que teremos uma renovação da fabricação de moedas na Inglaterra, e com as invasões de noruegueses, a introdução da cunhagem de moedas na Irlanda. Isto pode ser facilmente compreendido, uma vez que os vikings eram famosos mercadores e por fundarem ou tornarem cidades como centros comerciais. Apenas nas Ilhas Britânicas podemos contar, entre outras, com Londres, York, Dublin e provavelmente Norwich.

Pouco a pouco os ataques passaram a ser mais intensos, basta lermos a Crônica Anglo-Saxônica para comprovarmos isso. No início os ataques ocorriam em períodos mais esparsos de tempo, mas aos poucos eles se tornaram mais ininterruptos; o primeiro ataque registrado data de 789 e o segundo em 793, já o terceiro só irá acontecer em 832-

\footnotetext{
${ }^{69}$ A nova cunhagem de moedas só foi retomada por volta do século VIII. Mas na verdade o que temos é a cunhagem de uma moeda de prata (durante o governo de Offa de Mercia) de melhor qualidade da que estava circulando até então. Ver CAMPBELL, 1991, pp. 62-63.
} 
835. A partir deste último ataque, as investidas passam a ser freqüentes: 833-836, 837840, 838-841, 839-842, 845, 851-853 e assim continua até os tempos de Alfred, o Grande.

No âmbito religioso, a principal idéia era a de que as desgraças ocorridas na Inglaterra e os ataques dos vikings eram obras de Deus. O Senhor teria enviado os vikings sobre eles para puni-los, pois haviam se afastado de Cristo e provavelmente por persistirem com as práticas de alguns cultos pagãos. Em outra de suas cartas enviadas a Inglaterra, ao rei Æthelred da Northumbria, Alcuíno de York chega até mesmo a criticar os saxões por usarem barba, atacando sua vaidade, pois desta forma ficariam parecidos com os mesmos pagãos que tanto temiam e os atacavam ${ }^{70}$. Outro a quem podemos citar, mas já de um momento posterior, é Wulfstan, arcebispo de York e Worcester (c. 1002). Wufstan é responsável pelo sermão “Sermo Lupi ad Anglos”, no qual diz que a culpa do que estava acontecendo não estaria nas mãos do rei (Æthelred II), mas sim de todos os ingleses; pois estes teriam se afastado da religião cristã, destruindo e arruinando alguns monastérios e por permitirem que os assassinos de Edward, o Mártir (irmão de Æthelred II) ficassem impunes ${ }^{71}$. Este talvez seja o documento onde podemos encontrar com maior clareza a visão religiosa do momento, e principalmente em relação aos vikings; além disso, é também um dos poucos documentos a não depositar a total responsabilidade da crise do período em Æthelred II. A princípio, Wulfstan nos diz que tudo o que está acontecendo é nada mais que sinais do Juízo Final:

“Queridos homens, percebam o que é a verdade: este mundo está em ruínas e o fim se aproxima; e desta forma as coisas no mundo vão de mal a pior, e tudo está se deteriorando imensamente em relação aos pecados das pessoas antes da vinda do Anticristo, e isso será realmente terrível e apavorante por todo o mundo”, ${ }^{72}$

Ao longo do texto, Wulfstan estabelece um paralelo entre a fé dos cristãos e a dos pagãos, demonstrando uma maior dedicação dos últimos. Ou seja, os pagãos seriam mais devotos e fiéis a suas crenças do que os cristãos, por isso o Senhor estaria concedendo a vitória a eles, mesmo não sendo cristãos:

"Entre os pagãos ninguém ousa negar pouco ou muito daquilo que é designado para o culto de seus falsos deuses; e nós por toda parte negamos muito o que deve ser de Deus. E ninguém ousa entre os pagãos privar o santuário tanto interna quanto

\footnotetext{
${ }^{70}$ WHITELOCK, 1955, p. 776.

${ }^{71}$ CAMPBELL, 1991, p. 202.

${ }^{72}$ WHITELOCK, 1955, p.855.
} 
externamente das coisas que são dedicadas aos falsos deuses e entregues para os sacrifícios, e nós temos despojado completamente a casa de Deus tanto por dentro quanto por fora. E os servos de Deus ${ }^{73}$ são por toda parte privados de respeito e proteção; enquanto entre os pagãos ninguém ousa de qualquer forma fazer mal aos servos dos falsos deuses (...) e os piratas são tão fortes com o consentimento de Deus que muitas vezes em batalha um põe dez para correr, e às vezes menos, às vezes mais, mas tudo por causa de nossos pecados"74.

Ele acaba deixando como um alerta do que poderia acontecer a eles se baseando na história de Gildas a respeito do fim dos bretões. Ele faz um interessante paralelo com o trabalho de Gildas, a respeito da história dos bretões durante as invasões anglosaxônicas. Segundo o que ele conta, os bretões, por se afastarem da fé cristã e cometerem os mais diversos pecados, foram punidos por Deus enviando sobre eles os anglo-saxões, que os conquistaram e dominaram toda a Inglaterra. Agora, o que estaria acontecendo seria exatamente o mesmo, com a diferença que seriam os saxões a serem punidos com os vikings sobre eles:

"Havia um historiador nos tempos dos bretões, chamado Gildas, que escreveu sobre seus erros, como pelos seus pecados eles enfureceram Deus de tal forma que por fim Ele permitiu ao exército dos ingleses ${ }^{75}$ conquistar sua terra e destruir completamente toda a hoste dos bretões (...)"76. Ele então cita os diversos crimes e pecados cometidos pelos bretões, mas acaba completando dizendo que "nós sabemos de feitos muito piores cometidos entre os ingleses do que já ouvimos em qualquer parte entre os bretões (...), $)^{\text {,77. }}$

Com isso, Wulfstan conclui seu discurso alertando a todos, que se o povo não mudar de atitude e se voltar a Deus, o mesmo que aconteceu aos bretões irá acontecer com eles; e ainda mais com o agravante de que estariam próximos ao Juízo Final, e sua mudança de atitude seria não só para o bem do reino mas também para si próprios. Outro ponto importante na elaboração dessa visão religiosa dos escandinavos estaria vinculado a Bíblia, como o inimigo que vem do norte. Isto pode ser visto nas cartas de

\footnotetext{
73 bispos e abades, monges e freiras, padres e mulheres sob votos religiosos.

${ }^{74}$ WHITELOCK, 1955, p. 855 - 857.

${ }^{75}$ Devemos lembrar que os ingleses só serão chamados assim após a conquista dos saxões na ilha, uma vez que o local passa a se chamar Angeland (que se modificará mais tarde para England), “a terra dos anglos".

${ }^{76}$ WHITELOCK, 1955, p. 859.

${ }^{77}$ WHITELOCK, 1955, p. 859.
} 
Alcuíno e também no livro do profeta Jeremias ${ }^{78}$. Ao lermos Jeremias é clara sua influência referente não só aos ataques, mas também a questão de idolatrias e práticas pagãs. O livro de Jeremias se encaixa bem no sermão de Wulfstan (e, por que não dizer, em Beowulf em relação aos ataques de Grendel e os cultos pagãos dos versos 175-188). Dentre os livros das Sagradas Escrituras, entre os mais apreciados estariam justamente os profetas. Isto ocorria possivelmente devido a temática e a forma de se expressar ser semelhante ao mundo germânico anglo-saxão em que viviam ${ }^{79}$.

A Inglaterra foi o primeiro alvo das incursões escandinavas e assim permaneceu até o fim da Era Viking. As incursões restringiam-se a ataques rápidos sem grande interesse em fixação, mas isto mudou a partir do século IX. Por volta de 865, grupos de escandinavos passaram a vir cada vez em maior número e se fixando nos territórios conquistados: Northumbria, Anglia Oriental e boa parte de Mercia. Eles avançaram sobre várias partes da ilha e nomeavam “reis-fantoches” para governar seus territórios (por exemplo: rei Egbert da Northumbria). Em 874 o último reino livre da ocupação era Wessex, governado por Alfred, o Grande. Nos tempos de Alfred houve a maior onda invasora viking vista até então na Inglaterra; algo semelhante que só aconteceria no século XI, com Æthelred II.

Um elemento importante, que parece estar presente por toda a história da Inglaterra durante a época das invasões, são as constantes disputas internas entre os diversos reinos anglo-saxões. Desde o início da era anglo-saxônica essas disputas se faziam presentes. A princípio os confrontos eram entre anglo-saxões e bretões, obviamente por estes estarem habitando a região desde os tempos romanos. Mas uma vez a presença bretã tenha perdido sua força, os confrontos se voltam contra os próprios saxões $^{80}$. Este é certamente um dos fatores que favoreceram a ocupação por parte dos vikings, uma vez que enquanto lutavam entre si não davam a importância necessária aos ataques, e também mostravam aos vikings um quadro instável onde poderiam facilmente atuar.

Alfred havia conseguido expandir as fronteiras de seu reino, que agora se estendia por todo o sul da Inglaterra. Enfrentou os dinamarqueses, impedindo que

\footnotetext{
${ }^{78} \mathrm{Jr} 1: 14 ; 4: 6 ; 6: 22-23$.

${ }^{79}$ PAGE, 1997, p. 118.

${ }^{80} \mathrm{Um}$ exemplo disso foi a disputa pelo trono da Northumbria em York, em 866, entre Osbert (o herdeiro legítimo) e Ælla (um líder escolhido da população). Instaurou-se um clima de guerra civil em York que só terminou quando os vikings, que se aproveitaram da situação, tomaram a cidade e mataram ambos os reis, o que fez a população estabelecer a paz com seus atacantes e a ascensão de um "rei-fantoche” indicado pelos escandinavos. Ver CAMPBELL, 1991, pp. 135-155.
} 
invadissem Wessex; realizou tratados de paz e acordos. Em seu acordo de 886, ano em que reconquistou Londres, com o rei Guthrum, foi acertado que os dinamarqueses não mais atacariam, foi estabelecido a wergeld para evitar os ataques de ambas as partes, e foi estabelecida também as fronteiras da Danelaw (o território ocupado pelos vikings). O “Grande Exército”, assim chamado o exército dinamarquês, atuou aproximadamente de 865 a 874 na Inglaterra, de 874 a 892 permaneceram no continente e retornaram em torno de 892 permanecendo até 896. A partir de então passaram a ter mais derrotas que vitórias e muitos resolveram se fixar nos territórios conquistados da Danelaw. Pouco a pouco foram se dispersando e o Grande Exército desaparecendo.

A primeira conclusão que podemos tirar a respeito desse momento é que se não fosse por Alfred, toda a Inglaterra teria caído nas mãos dos escandinavos. Alfred deve seu sucesso principalmente devido a tática que utilizou, e que acabará tendo continuidade com seus descendentes (principalmente Edward I e Athelstan, que os espalham por toda a Inglaterra). Seu mérito está na utilização dos buhrs ${ }^{81}$, sendo de tal eficiência que graças a eles os vikings não conseguiram tomar Wessex e favoreceu os anglo-saxões a poderem contra atacar.

Apesar da inimizade contra os vikings, foi graças a eles que Wessex pode consolidar seu poder e, indo mais além, poder promover a unificação da Inglaterra sob a coroa da linhagem de Cerdic $^{82}$. Ao enfrentar os escandinavos, Alfred consolidou o poder de Wessex possibilitando que seu filho, Edward I, o Velho, iniciasse a transformação do reino de Wessex no reino da Inglaterra; entretanto, seria apenas com Athelstan como rei de toda a Inglaterra que esta situação se solidificaria, acabando por proporcionar a possibilidade de sucesso do rei Edgar. Em 917 Edward I, o Velho, fez com que os líderes dinamarqueses se submetessem a ele. Em troca foi-lhes concedido o direito de viver segundo seus próprios costumes. Com a morte de sua irmã, Æthelfleda de Mercia, foi lhe oferecido o trono do reino de Mercia. Desta forma Edward I, o Velho, o filho de Alfred, o Grande, tornava-se o primeiro senhor de todos os anglo-saxões, mas ainda não da Inglaterra.

Nos anos que se seguiram, os ataques vikings não foram como aqueles que haviam abalado a Inglaterra. Os sucessores de Alfred (Edward I, Athelstan, Edmund I e

\footnotetext{
${ }^{81}$ Os buhrs consistiam em fortificações criadas por toda Wessex durante o governo de Alfred, o Grande. Eram enormes fortalezas que tinham por objetivo abrigar as populações próximas contra os vikings, sendo pontos de resistência contra os escandinavos. Com base em algumas fontes, acredita-se que este sistema teria sido utilizado em menor escala na França e Alemanha por volta da mesma época e com os mesmos propósitos. Ver CAMPBELL, 1991, pp. 152-153.

${ }^{82}$ Cerdic foi rei de Wessex e fundador da dinastia da qual pertenceu Alfred e $Æ$ thelred II.
} 
Edred) mantiveram o perigo escandinavo afastado e puderam estabelecer bases do domínio inglês por todo o reino. Com Edgar a Inglaterra desfrutaria de um período de paz e organização administrativa. Entretanto, a ocupação escandinava era mais do que presente; como por exemplo: os nomes de muitas regiões do centro-norte e nordeste da Inglaterra possuem origem escandinava ou são híbridos (anglo-nórdicos ou hibernonórdicos), o que pode ser comprovado por descobertas arqueológicas de cemitérios vikings nestas regiões; porém, existem algumas exceções, como por exemplo em Ingleby $^{83}$, Derbyshire, um local de nome claramente de ocupação viking mas onde não foi encontrado nenhum túmulo escandinavo.

Na escultura e arte também encontramos a influência nórdica. Um bom exemplo são algumas cruzes que combinam elementos célticos, anglo-saxões e escandinavos. A cruz da igreja em Gosforth, Cumbria, foi esculpida em estilo característico céltico, mas possui imagens que nos chama a atenção. Dentre elas temos uma mulher, cujo estilo de cabelo é tipicamente escandinavo, e retrata um trecho do Ragnarök ${ }^{84}$ (a vingança de Viðarr, o filho de Óðinn, sobre o grande lobo Fenrir). Outro caso semelhante está na cruz da igreja de Middleton, North Riding, Yorkshire. Esta cruz data do século X, e podemos encontrar esculpida a figura de um guerreiro usando um elmo e espada muito parecida com um guerreiro viking do período. Outro caso é o elmo do túmulo de SuttonHoo, East Anglia, datado do século VII. No túmulo, que se acredita pertencer ao rei Redwald, morto por volta de 624, encontra-se um elmo que possui decorações claramente pertencentes ao estilo realizado na Suécia, na região de Uppsala, naquele período.

\footnotetext{
${ }^{83}$ Um dos típicos sinais de nomes compostos por elementos nórdicos é o sufixo -by (indicando uma vila) ou thorp (em regiões de uma segunda ocupação), mais comum nas regiões da Northumbria, que se acredita ter origem dinamarquesa. Ver ROESDAHL, pp. 245-247.

${ }^{84} \mathrm{O}$ Ragnarök é o apocalipse nórdico, quando haverá uma grande batalha entre os deuses. Mas como nas demais tradições pagãs, este não seria um fim, mas o início de um novo ciclo, quando o mundo irá renascer para uma nova fase. Ver DIXON-KENNEDY, pp. 192-193.
} 


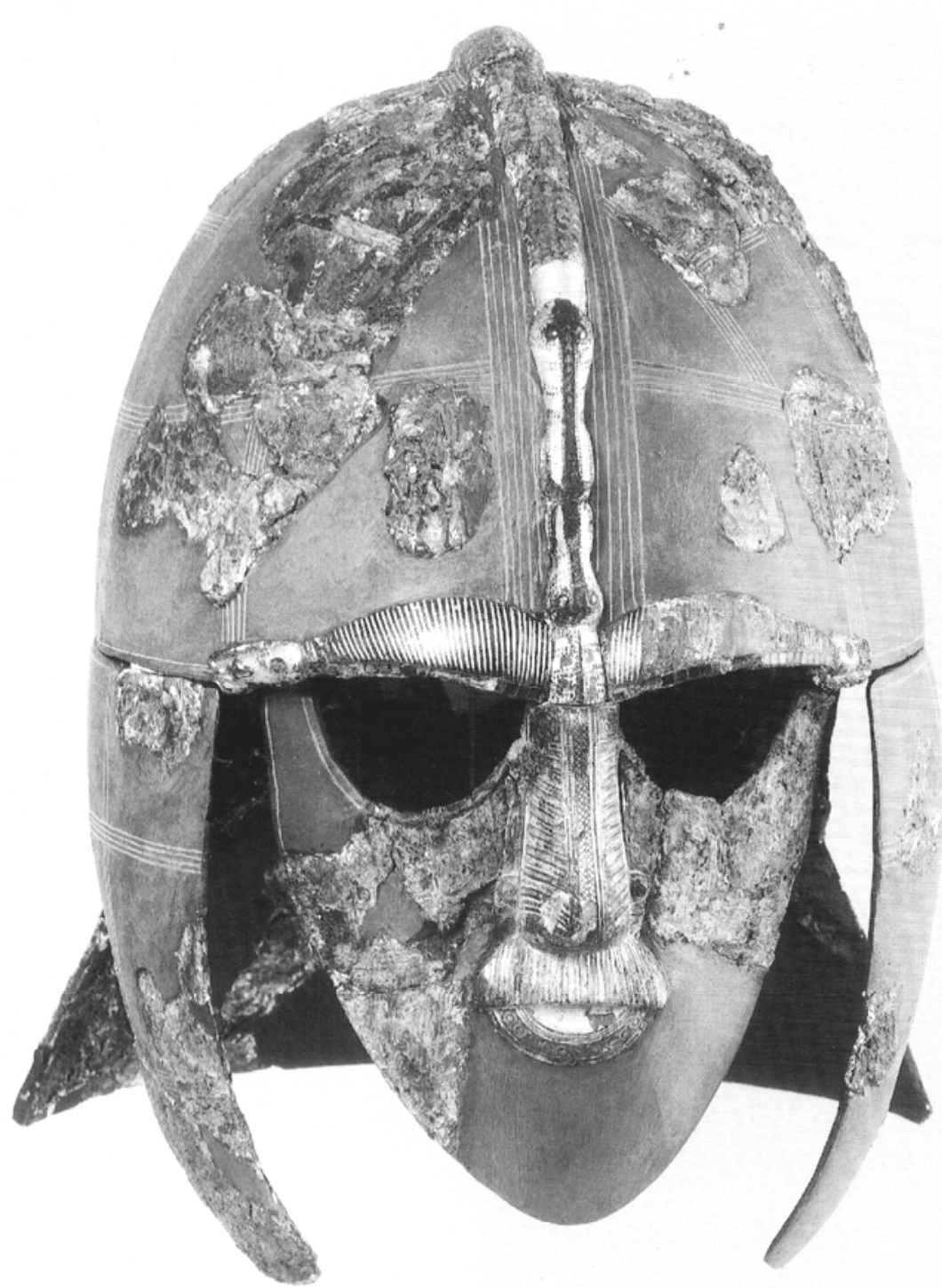

figura 4: O elmo de Sutton Hoo; a maior parte do elmo deveria ser coberta com pequenos painéis contento figuras, por exemplo, semelhantes ao dragão que forma o nariz e as sobrancelhas do elmo. Seu estilo é muito semelhante ao utilizado na Suécia do mesmo período. [Barbara Yorke. Kings and Kingdoms of Early Anglo-Saxon England, Londres: Routledge, 2002, p. 90] 
No campo político a influência escandinava também esteve presente. O título de earl (jarl ${ }^{85}$, era concedidos a todos os oficiais responsáveis pela administração das regiões do reino, principalmente nas áreas de ocupação dinamarquesa em seu início (Athelstan, por exemplo, teria nomeado os earls para a administração da Northumbria). Esta prática foi utilizada até o reinado de Cnut, quando o título se generalizou para todos os oficiais da Inglaterra, dinamarqueses e anglo-saxões. Nos tempos de Cnut o mais famoso dos earls foi Godwine de Wessex, pai de Harold Gowinson, o último rei anglo-saxão da Inglaterra.

Em códigos legais, como os de Edgar, faz-se referência de que as populações escandinavas poderiam viver sob seus próprios costumes e leis, mas sob a soberania do rei inglês. As populações camponêsas das regiões da Danelaw possuíam maior liberdade para com seus senhores do que os saxões. Basta vermos que as regiões de maior servidão coincidem com as áreas de influência anglo-saxônica, respectivamente Mercia e Wessex. É interessante vermos também que desde os tempos do rei Ine (688726), sempre esteve presente entre as leis inglesas artigos referentes à presença ilegal de estrangeiros. Durante o governo de Cnut havia uma lei, inspirada no código de Wihtred de Kent (695), na qual estrangeiros que não regularizassem seus casamentos sob os mandamentos da Igreja deveriam abandonar o país. Com esta lei visava-se principalmente o combate às práticas que ainda persistiam entre os saxões e, no governo de Cnut, também os dinamarqueses que não haviam se convertido ainda ${ }^{86}$.

\footnotetext{
${ }^{85} \mathrm{O}$ título de earl era concedido a oficias do rei, em geral a homens membros da nobreza, o que convencionalmente poderia corresponder a um título de conde. O jarl era a categoria mais alta da sociedade escandinava, correspondendo aos nobres. As demais categorias eram os karls (guerreiros) e os thralls (servos e escravos). É interessante ver que esta divisão tem uma explicação mitológica no poema Rigspúla, onde o deus Heimdall (que se apresenta como Rig) desce a terra dos homens (Miðgarðr) e visita a casa de três famílias, uma pobre, uma humilde porém com certa fartura e finalmente a de pessoas prósperas. Ele engravida as esposas desses homens e nascem então as crianças que darão continuidade as suas respectivas condições de servos e escravos, guerreiros e camponeses e nobres. Um fato curioso é de que o nome Rig entre os povos hiberno-célticos teria como significado "rei ou governante", o que poderia indicar certa influencia devido o contato com as regiões de origens célticas. Ver HILL, 1986, pp. 79-89.

${ }^{86}$ A Dinamarca se tornou oficialmente cristã no ano de 965. Cnut governou de 1016 a 1035, o que podemos considerar pouco tempo para que antigas tradições fossem abandonadas. Assim, seguramente muitos dos que habitavam as regiões de ocupação escandinava, ainda mantinha práticas e rituais pagãos. Não é necessariamente o caso, mas um exemplo de antigas práticas ainda em uso é a "Bandeira do Corvo". Segundo o autor da Encomium Emmae Regina (livro II cap. 9) a bandeira foi utilizada até mesmo pelo exército de Cnut na batalha de Ashingdon. A Bandeira do Corvo era um objeto mágico onde estaria a figura de um corvo, que era levada para o campo de batalha para prever o futuro do combate. Se ao vento o corvo batesse as asas era sinal de que o exército seria vitorioso; caso o corvo se mantivesse quieto, seria a derrota certa. Vale lembrar que o corvo era um dos animais símbolos da guerra entre os nórdicos, além de ser um dos animais sagrados de Odin; que possuía dois deles, Huginn (o pensamento) e Muninn (a memória), que voavam por o dia todo pelo mundo e ao anoitecer pousavam sobre os ombros de Odin, lhe contando tudo o que viram.Ver DAVIDSON, 1988, pp.98-99.
} 
Apesar dos ataques e muitas vezes serem vistos como pagãos sanguinários, em algumas regiões da Inglaterra eles eram mais aceitos do que os lordes saxões. Um dos motivos seria a segurança que os vikings poderiam lhes dar; segurança essa que seus antigos senhores não puderam proporcionar (contra os próprios vikings). Um episódio que pode demonstrar bem isso foi a respeito dos monges de São Cuthbert, na Northumbria, que adotaram como protetor e rei um escravo oriundo das tropas dinamarquesas. Este foi então escolhido sob a condição de que, mais tarde, jurasse sobre as relíquias do santo que iria protegê-los e dar abrigo às relíquias. A escolha não foi por um saxão, visto que no passado os governantes da Northumbria haviam atacado suas igrejas por várias vezes; o que nos faz lembrar das palavras de Wulfstan quando diz que mesmo os pagãos respeitavam mais seus locais sagrados do que os próprios saxões. Assim, seria melhor ter por rei um homem que tivesse jurado fidelidade a São Cuthbert, mesmo este sendo um viking, do que os lordes saxões de até então ${ }^{87}$. Aliás, o santuário de São Cuthbert foi de extrema importância, pois graças a ele, Durham desempenhou grande influência em toda a Inglaterra como sendo centro de peregrinações. Para os vikings também foi importante a existência do santuário, pois ele foi um dos meios dos quais eles puderam usufruir para impor seu domínio na Northumbria.

Nos tempos de Athelstan e Eadred as incursões persistiram, mas já com pouca intensidade. Na verdade as únicas grandes ameaças foram os confrontos contra os reis de York e Dublin (Olaf Sithricson e Guthfrith), a aliança Dublin-Strathclyde-Escócia na batalha de Brunanburh em 937, Olaf Guthfrithson (rei de Dublin) em sua tentativa de conquistar York, e finalmente contra Erik Bloodaxe (o filho de Harald Finehair e irmão de $\operatorname{Hakon}^{88}$, o Bom, ambos reis da Noruega). Apesar disso, estes já eram os últimos ataques vikings que realmente ameaçavam a Inglaterra. Devido a isso, o contingente do exército inglês também passou a ser reduzido. Entretanto, o fato de reduzir o tamanho do exército pode estar tanto relacionado aos poucos ataques ocorridos, mas também pode mostrar que os armamentos estariam ficando mais caros, uma vez que era preciso uma quantidade muito grande de equipamento para suprir o número de homens. Esta redução do contingente da Inglaterra chegou ao tempo de Edgar com a exigência de

\footnotetext{
${ }^{87}$ Provavelmente, seria este também uma das razões para aceitação de Cnut como rei da Inglaterra.

${ }^{88}$ Hakon, o Bom era o filho de Harald o Louro, mas foi criado na corte de Athelstan da Inglaterra. Por isso, ele também é conhecido como Hakon Aðalsteinfostri ("filho adotivo de Athelstan”).
} 
apenas dois homens por hide ${ }^{89}$, e um elmo e uma armadura a cada seis hides. Foi também no governo de Edgar que se instituiu a obrigação de construir um barco e provê-lo com sessenta homens por shipsokes ${ }^{90}$. Com a frota (shipfyrd) proporcionada por esta obrigação, Edgar pode manter a ameaça externa longe de seu reino; principalmente devido as constantes circunavegações que a shipfyrd realizava nas ilhas britânicas, mantendo assim o perigo mais próximo neutralizado: o reino de Dublin ${ }^{91}$.

Outra parte do exército inglês era o fyrd, sendo este o exército propriamente dito. O fyrd consistia num grupo militar de uma região, sob a liderança de um comandante. No poema A Batalha de Maldon a fyrd em questão era liderada por ealdorman Byrhtnoth. Mas com base em outras fontes, podemos ver que a hundred era na verdade uma unidade administrativa, consistindo de aproximadamente doze homens, os thengs ${ }^{92}$, em geral escolhidos pelo earl local. Existe um documento datado entre 939-961, chamado The Hundred Ordinance (sobre o qual existe a dúvida se o responsável por ele seria Edmund I ou Edgar), onde está a descrição legal e o funcionamento das hundreds. Sua função seria semelhante a de um conselho regional, responsável no auxílio da administração do shire ou earldom. Esta identificação entre hundred e fyrd vem provavelmente da obrigação do recrutamento de homens que a hundred tinha para compor o exército inglês. A hundred apesar de nos parecer uma forma política típica anglo-saxônica, também tem sua origem escandinava, supostamente vinda das things. Entretanto, durante o período carolíngio chegou a haver algo semelhante; o que não chega a ser uma surpresa, visto que, como sabemos, os francos também tinham uma origem germânica.

No reinado de Edgar (959-975), como podemos ver, houve importantes ações no campo político e principalmente religioso. Em seu governo praticamente não ocorreram ataques dos vikings. Enquanto isso, na Escandinávia, conflitos internos como a disputa pelo trono dinamarquês entre Harald I Dente-Azul e seu filho Sweyn Barba-Bifurcada,

\footnotetext{
${ }^{89}$ A "hide" (hid ou hiwisc) era uma medida de terra, correspondente a unidade (em geral cultiváveis) sob os cuidados de camponeses. Sua extensão variava, sendo 120 acres em Cambridge enquanto em Wessex ela chegava a ser bem menor (em torno de 40 acres de terra).

${ }^{90} \mathrm{O}$ típico sistema de divisão política na Inglaterra eram os shires. Estes por sua vez eram subdivididos em hundreds (que no território da Danelaw eram chamados wapentakes). Um conjunto de três hundreds consistia num shipsoke.

${ }_{91}$ JOHN, 1991, pp. 160-191.

${ }^{92}$ Thengs ("aquele que serve a outro") era mais uma condição do que uma distinção social. Eles eram homens que mantinham relações de obediência a um senhor. A importância dos thengs dependia do poder de seu senhor, que podiam ser earls, mas os de maior importância eram aqueles ligados diretamente ao rei. Nos tempos de Alfred eram os thengs que o mantinham informado a respeito dos acontecimentos no reino e auxiliavam na administração.
} 
abalavam a Dinamarca, que também acaba por invadir a Noruega. Ao falarmos da invasão da Noruega, sempre se pensa a respeito de Cnut, o Grande e São Olaf, mas sabe-se que a Noruega teria sofrido invasões dinamarquesas em ocasiões anteriores. Basta vermos o caso da esposa de Harald Dente-Azul, que é citada nos documentos como tendo vindo das regiões do norte da Dinamarca. O norte dinamarquês era nada mais do que a Noruega, enquanto que o sul era respectivamente a Dinamarca propriamente dita. Assim, por estarem ocupados com batalhas e disputas internas, os vikings não tiveram tempo para se voltar contra a Inglaterra no século $\mathrm{X}$, e os poucos ataques ocorridos foram facilmente repelidos pelo exército de Edgar. Podemos até mesmo chegar a conclusão de que parte do sucesso de Edgar em manter sua costa livre do perigo escandinavo estaria não apenas na eficiência de seus homens, mas também no baixo número de homens nos ataques escandinavos. Apesar do período de paz existente na Inglaterra e as mudanças religiosas ocorridas, foi no governo de Edgar que se iniciou a crise que acabaria eclodindo na época de Æthelred II, resultando na ascensão de Cnut ao trono inglês.

No estudo da Inglaterra anglo-saxônica, a figura de Æthelred II é sempre vista com certo desprezo devido a sua incompetência ao lidar com os vikings, exatamente oposta a Alfred, o Grande. Alfred deve toda sua glória a sua ação em expulsar os escandinavos, enquanto com Æthelred II ocorre exatamente o oposto. Entretanto, poucos se atem ao fato de que as raízes do insucesso de Æthelred II encontram-se no governo de seu pai, o qual é conhecido justamente por ter sido um governo próspero e livre da ameaça externa.

Vários fatores importantes influíram para a vitória escandinava sobre Æthelred II. Poderíamos identificar três principais responsáveis pela ascensão de Cnut, o Grande. Primeiramente, podemos partir do princípio que Æthelred II não estaria preparado para um ataque de tão grandes proporções como as que ocorreram. Como já foi dito, o contingente do exército saxão havia diminuído muito desde os tempos de Athelstan, quando ainda havia ameaças consideráveis para se preocupar. Havia mais de trinta anos quando os últimos vikings haviam atacado, e mesmo esses ataques eram de pouca força. Agora os vikings, com um quadro estabilizado na Escandinávia, se voltavam uma vez mais para o reino inglês. O que nos chama atenção para um segundo ponto importante, que era a natureza dos atacantes. Nos tempos de Alfred, o Grande e do "Grande Exército” os homens que chegavam à Inglaterra eram simples guerreiros 


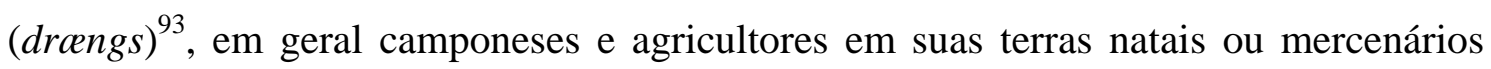
(víkingr). Os vikings enfrentados por Æthelred II tinham duas características diferentes de seus antecessores: muitos eram cristãos e nobres (jarls). Diferentemente dos anteriores, eles não eram mais liderados por chefes guerreiros ou capitães de embarcações, mas sim por reis e príncipes. A única exceção deste período foi Thorkell, o Alto, talvez o último chefe escandinavo ao velho estilo viking da félag. O caso de Torkell é interessante visto que ele não era de nenhuma família nobre e seus homens eram leais a ele, sendo quase que um exército exclusivo, uma fraternidade de guerreiros.

Uma questão levantada e que estaria ligada diretamente a esta nova onda de ataques e de certa forma ao próprio Thorkell, é a respeito dos sucessivos pagamentos feitos aos vikings. Antes de tudo, o famoso pagamento feito aos vikings, o danegeld, só será chamado desta forma em fontes pós-conquista normanda ${ }^{94}$. Sua origem estaria na heregeld (“dinheiro do exército”), utilizado para pagar aos homens de Thorkell durante seus serviços ao lado dos saxões. O dinheiro era recolhido nas hides, em geral sendo feito por um funcionário senior do shire (o que mais tarde passou a receber o nome de sheriff); vemos que mais uma vez a presença escandinava contribuiu, mesmo que indiretamente, para a construção da sociedade anglo-saxônica. É claro que anteriormente, desde os ataques no século IX que ocorriam certo pagamento aos vikings, mas esses não eram realizados de forma tão organizada quanto estes últimos. Ainda a respeito dos pagamentos de danegeld, algumas fontes nos fazem levantar a questão de que a Inglaterra teria pagado por sua invasão. Podemos chegar a esta conclusão devido a achados arqueológicos na ilha de Götland (Suécia), onde foram encontradas centenas de moedas de várias partes da Europa, mas principalmente da Inglaterra dos tempos de Æthelred II. Além disso, nos próprios relatos da Crônica Anglo-Saxônica podemos ver a progressão nos valores da danegeld (em torno de 10.000 libras no ano de 991 para 72.000 libras em 1018). Desta forma, a Inglaterra estaria suprindo seus invasores com recursos para melhorias em seus homens, o suficiente para tomá-la e (segundo alguns pesquisadores) incentivado a invasão do que a uma simples pilhagem, pois os vikings teriam considerado o reino inglês como uma região rica, visto

\footnotetext{
${ }^{93}$ Era uma prática comum entre os povos escandinavos a existência de guerreiros, que em geral acabavam se concentrando em grupos (félag) de aventureiros e mercenários. Fato que esta presente em diversas sagas.

${ }_{94}$ JOHN, 1991, pp. 201.
} 
os valores pagos a eles ${ }^{95}$. Além disso, com base nestas mesmas pesquisas arqueológicas, vemos que os exércitos não eram formados exclusivamente por noruegueses e dinamarqueses. Em pedras rúnicas na Suécia podemos ver inscrições que falam sobre homens que teriam recebido pagamentos de vários governos e senhores, em especial temos uma pedra em Yttergärde, Uppland, erguida em honra a um homem chamado Ulf de Borresta, o qual teria recebido tributos na Inglaterra por três vezes sob a liderança de Tostig, Thorkell e Cnut.

Finalmente, o terceiro ponto de importância para a crise do governo de Æthelred II teria sido os conflitos envolvendo a Igreja no reino de seu pai, devido a reforma religiosa na Inglaterra do século X. Antes mesmo do século X, a maioria das terras da Igreja eram na verdade propriedades de famílias de certa influência, que acabavam interferindo no andamento dos trabalhos destas comunidades pois muitos dos religiosos que lá estavam eram seus familiares. A nobreza anglo-saxônica estava diretamente ligada a Igreja (o que a faz ser parte integrante dessa aristocracia). A Igreja anglo-saxônica, assim como a franca, era uma Adelskirche: uma Igreja da nobreza. Assim, temos um grupo social eclesiástico de cunho aristocrático, um grupo que mesmo na Igreja, mantém as praticas e costumes da nobreza. Este quadro só irá sofrer alterações nos séculos X e XI com reforma.

Sinais da reforma já vinham desde os tempos da hegemonia de Mercia sobre a comunidade de Canterbury, mas foi com Edgar que ela tomou força. A reforma para a introdução da Regra de São Bento gerou um clima de disputas e revoltas por toda a Inglaterra não só no campo religioso, mas também entre nobres e regiões do reino, visto que muitas famílias tinham ligações fortes com certas comunidades e não gostariam de perder este laço com mundo eclesiástico. Devido a crise da reforma religiosa, acabaremos tendo um panorama instável no final do governo de Edgar. Crise esta que vai se agravar quando da sucessão ao trono ${ }^{96}$.

Edgar morre em 975 deixando como herdeiros seus dois filhos, Edward e Æthelred. A crise devido a reforma fica clara neste momento, pois Edward tinha o apoio da corrente monástica, liderada por Æthelwine, ealdorman de East Anglia. Por outro lado, Æthelred tinha o amparo da corrente anti-monástica, cujo líder era Ælfhere de

\footnotetext{
${ }^{95}$ Durante o governo de Æthelred II foi o período em que mais se pagou o danegeld, tanto que até Wulfstan se revolta com as quantidades de vezes e somas pagas aos escandinavos. Ele parece realmente irritado e diz que os vikings continuamente os insultam e mesmo assim eles lhes pagam tributos. Ver WHITELOCK, 1955, p. 858.

${ }^{96}$ JOHN, 1991, pp. 181-189: Esta reforma religiosa ocorrida na Inglaterra estava diretamente ligada ao que ocorria no continente, mais especificamente com a abadia de Cluny.
} 
Mercia, que provavelmente foi o responsável pela assassinato de Edward (por isso chamado “o Mártir”).

Com a reforma, os membros da Igreja não apenas se voltaram para a Regra de São Bento, mas também para as leis canônicas (principalmente a respeito das leis matrimoniais). Assim, visto que os membros da Igreja eram as autoridades supremas em relação às leis do matrimônio, eles poderiam declarar um casamento legítimo ou não. Todos sabiam que os grandes senhores mantinham relações consideradas como incestuosas pela Igreja, ou seja, uma relação onde ambas as partes possuíssem um ancestral em comum. Isto poderia fazer com que possíveis herdeiros perdessem seus direitos para tios, meio-irmãos e primos ansiosos por uma parte da herança. Foi exatamente este debate que teria ocorrido quando da morte de Edgar, na abadia de New Minster em Winchester. Edward acabou por ser considerado como protegido de Edgar, devido a sua mãe possuir certo grau de parentesco com o rei; enquanto apenas Æthelred foi considerado filho legítimo. Entretanto, Æthelred ainda não tinha nem mesmo dez anos de idade, o que fez Edward ser considerado "legítimo o bastante” por São Dunstan e São Æthelwold para subir ao trono.

Nos tempos de Æthelred II, durante a retomada dos grandes ataques, podemos ver dois pontos importantes: a rigidez das leis e a importância da religiosidade. Um documento que pode nos demonstrar este fato é o código de leis de Æthelred II, chamado de Wantage (ou III Æthelred), datado entre 978 - 1008. A princípio nos parecem um conjunto de leis com o objetivo de manter a paz no reino (principalmente

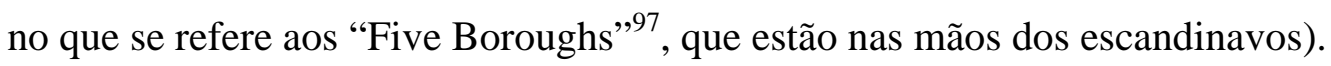

Logo no início fica claro a importância religiosa e política das relíquias e das ordálias. Ambos os elementos sempre foram importantes, porém o que é interessante é que sua importância aumenta muito mais durante esse período:

“3.1. E cada encontro deve ser mantido em cada wapentake, e os doze theng líderes (...) devem ir e jurar sobre as relíquias que são postas em suas mãos para que eles não acusem nenhum inocente nem ocultar algum culpado.”98

Em relação as ordálias, temos, no parágrafo 4 do código de Æthelred II, uma observação em que tanto o acusado quanto o reclamante, que não comparecessem ao dia do julgamento seriam postos à prova das ordálias. Mas elas não se restringem apenas a eles. Outros que também são alvos de ordálias são os falsificadores de moedas; e

\footnotetext{
${ }^{97}$ Nome dado a regiões das cidades de Lincon, Derby, Nottingham, Leicester e Stamford.

${ }^{98}$ WHITELOCK, 1955, p.403.
} 
também aos próprios responsáveis pela emissão das moedas verdadeiras; ambos, em caso da confirmação de sua culpa, acabariam sendo executados:

“8. E todo aquele responsável pelo tesouro que é acusado de cunhar dinheiro falso, desde que este era proibido, será submetido a três provas de ordália; se for provado que é culpado, ele será morto”99.

É claro que o alcance do julgamento divino tinha certos limites. Os thengs, não chegavam a passar pelas ordálias, porém eram obrigados a pagar indenizações por certas irregularidades. Não que isto já não fosse realizado, mas durante este período essas penas tornam-se mais rígidas, mais severas do que em governos anteriores.

Há maiores evidências da preocupação com a fé e a segurança política do reino num outro documento de Æthelred II, o “V Æthelred”. Este decreto data de 1008, e faz clara menção a práticas pagãs que ainda persistiam e suas tentativas de reprimi-las. Os próprios saxões ainda possuíam muitos costumes de seus antepassados que não seriam facilmente esquecidos, e junto a isso os vikings que só recentemente haviam sido cristianizados $^{100}$. No parágrafo 2 é bem clara a visão frente aos vikings: “os pagãos”.

Podemos ver que a preocupação religiosa no governo de Æthelred II era realmente muito séria, visto as palavras do bispo Wulfstan. No decreto “V Æthelred” (e depois no VI Æthelred, e VII Æthelred) podemos comprovar o que Wulfstan dizia:

“1.2. a paz e a amizade devem ser mantidas tanto no campo religioso quanto secular (...) 34. Nós devemos todos amar e louvar um Deus e abandonar completamente as práticas pagãs”101

Era um momento muito difícil que a Inglaterra estava enfrentando, e qualquer coisa que pudesse ser um obstáculo da intervenção divina deveria ser exterminada. No artigo 7 do decreto "VI Æthelred”, temos o que poderia ser de certa forma uma medida em resposta as denúncias do bispo Wulfstan:

"E se magos ou feiticeiras, mágicos ou prostitutas, assassinos ou perjuradores são pegos em qualquer parte desta terra, eles serão cuidadosamente enviados para fora de nosso país, e esta nação será purificada, ou eles serão completamente destruídos deste país, ao menos que eles desistam e se redimam profundamente"102.

\footnotetext{
${ }^{99}$ WHITELOCK, 1955, p. 404.

${ }^{100}$ A Dinamarca é oficialmente dada como cristã em 965, enquanto todo o restante da Escandinávia o é por volta do ano 1000. Ou seja, muito pouco tempo para que os antigos cultos e práticas fossem postos de lado.

${ }^{101}$ WHITELOCK, 1955, pp. $405-409$.

${ }^{102}$ WHITELOCK, 1955, p. 405.
} 
As palavras de Æthelred II não deixam dúvidas que o pensamento exposto por Wulfstan era corrente no período, sendo reforçado e posto a prova no edito de 1009 (o “VII Æthelred”) que é lançado logo após um novo ataque dos escandinavos (liderados por Thorkell, o Alto). Neste edito podemos perceber uma profunda angústia, um real desespero se abateu sobre a Inglaterra. O ponto principal em relação este documento é a importância, e uma imposição, das práticas religiosas; tanto que segundo o edito, acabam sendo reservados três dias para as cerimônias. As condições para as cerimônias demonstram quão desesperançados eles estavam frente à ameaça nórdica. Dentre as condições podemos encontrar trechos em que todos deveriam participar dos serviços nas igrejas, deveriam ir descalços e sem qualquer tipo de ornamento em sinal de humildade; deveriam também fazer doações em dinheiro e alimento que seriam distribuídos pelos clérigos. Os escravos deveriam ser liberados de suas tarefas para que eles também pudessem participar das cerimônias, mas caso não comparecessem eles seriam açoitados (enquanto homens livres deveriam pagar 30 pences e os thengs 30 shillings). O final do edito termina de forma que, como foi dito, só serve para confirmar a visão de Wulfstan em relação aos ataques e da preocupação religiosa do período:

“6.3. E a cada missa toda a comunidade, prostrados perante o altar de Deus, cantará o salmo: "Por quê, Oh Senhor, eles são tão numerosos?”103 (...) E todos juntos, eclesiásticos e leigos, deverão se voltar ansiosamente para Deus e merecer sua misericórdia (...) Deus nos ajude. Amén”104.

Com o edito de 1009 não restam dúvidas sobre a questão do aumento da importância religiosa durante o governo de Æthelred II, e também em relação à visão da explicação da razão dos ataques. Assim, os vikings seriam o instrumento de Deus para punir os saxões que haviam se degenerado e se afastado da fé cristã. Desta forma, fica claro o momento de crise pelo qual estava passando a Inglaterra.

As rivalidades que apareceram durante este período de ascensão ao trono são fundamentais para podermos compreender a quantidade de supostos equívocos e traições durante a resistência contra os vikings. Como podemos ver, Edward tinha oposição de Mercia, mais precisamente de Mercia ocidental, apesar do apoio de Kent e talvez da Northumbria. Seu apoio de Anglia Oriental e de Mercia Oriental se deve a seu pai, pois Edgar teria feito uma aliança com Mercia Oriental contra Mercia Ocidental. O reflexo desta aliança veio à tona no governo de Æthelred II. Talvez agora fique claro

\footnotetext{
${ }^{103} \mathrm{Sl} \mathrm{3,} 2$.

${ }^{104}$ WHITELOCK, 1955, pp. 410- 411.
} 
porque dos equívocos e desencontros (talvez propositais) cometidos por Mercia durante o período de Æthelred II e Edmund II “Ironside”. O que temos então é a disputa entre os dois grupos rivais de Mercia, que acabou abalando a resistência anglo-saxônica contra os escandinavos. Isto de certa forma explicaria a posição de ealdorman Eadric Streona, que hora apoiava os saxões, hora apoiava os escandinavos; talvez ele estivesse apenas esperando o momento certo para que pudesse escolher definitivamente pelo lado vencedor. Basta vermos na Crônica Anglo-Saxônica para comprovar isso:

“1012 - Neste ano Ealdorman Eadric e todos os conselheiros chefes da Inglaterra, eclesiásticos e laicos, vieram a Londres antes da Páscoa (...) e lá ficaram até que o tributo, respectivamente 48.000 libras, fosse todo pago após a Páscoa (...). 1016 (...) Então Ealdorman Eadric fez o que já havia feito anteriormente: ele foi o primeiro a começar a fuga com os mangonscete $e^{105}$, e então traiu seu senhor e todo o povo da Inglaterra. E lá Cnut teve a vitória e ganhou sozinho todo o povo da Inglaterra.”106 Durante os relatos das batalhas contra os vikings, encontramos desencontros de tropas, atrasos na construção de embarcações e convocações de homens para o exército e traições. Mas embora tudo isso tenha ocorrido, na Crônica Anglo-Saxônica, Æthelred II nos parece ter recebido certo reconhecimento, ou ao menos é assim que o autor parece ter pretendido nos passar:

“1016 (...) Então aconteceu que o rei Æthelred morreu antes que os navios chegassem. Ele terminou seus dias no dia de São Jorge, e manteve este reino com grande trabalho e dificuldades tanto quanto sua vida o permitiu.”107

Como havíamos levantado a questão anteriormente, realmente Æthelred II não foi de todo responsável pela conquista dinamarquesa da Inglaterra, uma vez que a causa dos problemas já vinham de longa data. Ao identificarmos as principais causas da crise na política inglesa de Æthelred (a crise devido a reforma religiosa, a natureza dos membros dos novos ataques vikings e o despreparo do exército inglês), podemos dizer que se outro estivesse ocupando o trono inglês, provavelmente os fatos não teriam sido muito diferentes. Talvez o principal problema de Æthelred II seja em ter sido rei da Inglaterra justamente neste momento.

\footnotetext{
105 A população de Herefordshire.

${ }^{106}$ WHITELOCK, 1961, pp.91-96.

${ }^{107}$ WHITELOCK, 1961, p. 95.
} 


\section{II.2 - A linhagem de Cerdic}

Dentre as mais conhecidas fontes primárias na historiografia medieval inglesa, uma das mais importantes é a Anglo-Saxon Chronicle (Crônica Anglo-Saxônica). A Crônica faz um relato ano a ano dos acontecimentos mais importantes ocorridos, desde o início da era cristã até o ano de 1154.

Ao consultarmos a Crônica Anglo-Saxônica, a respeito dos anos de 855-858 (devido as variações das fontes), teremos algumas informações a respeito de Æthelwulf, rei de Wessex. Nesta passagem da Crônica, é dito que os pagãos (os vikings) teriam se estabelecido em Sheppey durante o inverno, que o rei concedeu por decreto a décima parte das terras do reino em honra do Senhor, e que ele também teria ido a Roma, e lá permanecido por um ano. Entretanto, é o que segue as estas informações que devemos prestar a devida atenção:

“(...) E dois anos após ter retornado da França, ele morreu, e seu corpo foi sepultado em Winchester, e ele havia reinado por 18 anos e meio. E Æthelwulf era o filho de Egbert, o filho de Ealhmund, o filho de Eafa, o filho de Eoppa, o filho de Ingild. Ingild era irmão de Ine, rei dos Saxões do Oeste, que manteve o reino por 37 anos e que mais tarde foi para junto de São Pedro e findou sua vida lá. E eles eram filhos de Cenred. Cenred era o filho de Ceowold, o filho de Cutha, o filho de Cuthwine, o filho de Ceawlin, o filho de Cynric, o filho de Creoda, o filho de Cerdic. Cerdic era o filho de Elesa, o filho de Esla, o filho de Gewis, o filho de Wig, o filho de Freawine, o filho de Freothogar, o filho de Brand, o filho de Bældæg, o filho de Woden, o filho de Frealaf, o filho de Finn, o filho de Godwulf, o filho de Geat, o filho de Tætwa, o filho de Beaw, o filho de Sceldwa, o filho de Heremod, o filho de Itermon, o filho de Hathra, o filho de Hwala, o filho de Bedwig, o filho de Sceaf, i.e. o filho de Noé. Ele nasceu na arca de Noé. Lamech, Methuselah, Enoch, Jared, Mahalaleel, Cainan, Enos, Seth, Adão o primeiro homem e nosso pai, i.e. Cristo. (Amén.)”108

Segundo Marc Bloch ${ }^{109}$, os reis germânicos eram sacralizados por meio de suas linhagens, e não simplesmente por seus méritos em combate e sua bravura:

"Reges ex nobilitate, duces ex virtute sumunt". ${ }^{110}$

\footnotetext{
${ }^{108}$ WHITELOCK, 1961, p. 44.

${ }^{109}$ BLOCH, 1998. pp. 68-81.
} 
Podemos observar aqui uma demonstração a respeito da importância da ancestralidade, da linhagem real. Ao pegarmos outras referências da Crônica, é interessante vermos essas construções genealógicas e a relação com a conversão dos primeiros reis saxões ao cristianismo. O primeiro relato a este respeito se dá em 449, ao falar sobre os dois irmãos Hengest e Horsa. No relato deste ano é dito que Hengest e Horsa eram filhos de Wihtgils, que por sua vez era:

"filho de Witta, filho de Wecta, filho de Woden. E de Woden é descendente toda nossa família real, e também aquela dos Southumbrianos.”111

A referência a Woden claramente indica uma provável origem divina da família ligada a figura do deus Woden, o Wotan dos germânicos, ou o Odin dos escandinavos. Em 597 a Crônica nos diz sobre Ceolwulf, que teria iniciado seu reinado em Wessex, e que seria:

"filho de Cutha, filho de Cynric, filho de Cerdic, filho de Elesa, filho de Esla, filho de Gewis, filho de Wig, filho de Freawine, filho de Freothogar, filho de Brand, filho de Bældæg, filho de Woden"112.

Após este relato haverá outros que citam suas linhagens, porém é só por volta de meados do século IX que surge a primeira linhagem que combina sua origem divina com uma tradição cristã. Trata-se justamente da linhagem de Æthelwulf; entretanto, essa linhagem pode nos dizer muito mais do que uma legitimidade por ascendência.

Em certo momento, o registro genealógico do rei Æthelwulf refere-se ao nome Beaw, e este por sua vez seria:

“o filho de Sceldwa (...)o filho de Sceaf”.

É interessante notarmos que tal ascendência tão extensa e, em especial, esses nomes em específico, aparecem na Crônica Anglo-Saxônica apenas neste registro sobre Æthelwulf. Um outro fato, que será de grande relevância para analisarmos, é que Æthelwulf nada mais era que o pai de Alfred, o Grande.

A Crônica, como nós a temos hoje, é a união de vários relatos feitos durante toda a história da Inglaterra que acabaram por serem reunidos numa única obra. Existem sete versões conhecidas, chamadas respectivamente de versões A, B, C, D, E, F e G. Até o reinado de Alfred, o Grande os relatos são esparsos e muitas vezes confusos,

\footnotetext{
${ }^{110}$ Tácito, Germânia, VII: “Os reis vem de nascimento nobre, e seus comandantes são por seu valor”. Mas, além disso, outro elemento a ser levado em consideração são as particularidades do conceito da sacralidade da realeza germânica, que iremos aprofundar no próximo capítulo.

${ }^{111}$ WHITELOCK, 1961, p. 10.

112 WHITELOCK, 1961, p.14.
} 
informando apenas os nomes de imperadores romanos, santos, papas e mais tarde os primeiros reis saxões a se fixarem na Inglaterra. Foi Alfred quem ordenou uma melhor organização dos registros; isto ocorrendo em torno do ano de 890, marcando justamente a ascensão da casa de Wessex. Isto pode ser comprovado ao lermos a Crônica, pois os relatos de seu governo e posteriores passam a ser mais precisos dos que aqueles que os antecedem.

Por volta do ano de 980, temos um novo documento na região de Wessex. O documento em questão é a Chronicon Athelweardi (Crônica de Athelweard). Sua autoria é dada earl Æthelweard, descendente de Æthelred I, irmão de Alfred, o Grande. Desta forma, Æthelweard seria membro da família real e da casa de Wessex.

A Crônica de Athelweard (que no início ele nos diz que dedica sua obra a sua prima Mathilda, abadessa de Essen, a qual era neta de Otto I e Edith, filha de Edward I, o Velho) teria sido feita a partir de um exemplar da Crônica Anglo-Saxônica, sendo então traduzida para um latim extremamente confuso e com adaptações do inglêsantigo. Assim como a Crônica Anglo-Saxônica, a obra de Æthelweard também faz um relato anual dos principais acontecimentos, até o reinado do rei Edgar. Referente ao ano de 855, seu relato é muito semelhante ao encontrado na Crônica Anglo-Saxônica. Aqui também encontramos os relatos os vikings acampados em Sheppey, sua doação de terras ao serviço do Senhor e sua viagem a Roma. Entretanto, com relação a ascendência de Æthelwulf encontramos certas diferenças muitos interessantes:

"Denique post annum Athulf rex obiit, cuius corpus requiescit in urbe Vuintona. Igitur præfatus rex fuit filius Ecgbyrhti regis, cuius auus Ealhmund, proauus Eafa, atauus Eoppa, abauus Ingild, Ines frater, Occidentalium Anglorum regis, qui Romæ finierat uitam, traxeruntque supra dicti reges a Cenred rege originem. Cenred fuit filius Ceoluunald. Auus quippe eius Cuthuuine, proauus Ceaulin, atauus Cynric, abauus Cerdic, qui et primus possessor Brittanniæ partis occidentalis superatos exercitus Brittannorum, cuius pater fuit Elesa, auus Esla, proauus Geuuis, atauus Vuig, abauus Freauuine, sextus pater eius Frithogar, septimus Brond, octauus Balder, nonus Vuothen, decimus Frithouuald, undecimus Frealaf, duodecimus Frithouulf, tertius decimus Fin, quartus decimus Goduulfe, quintus decimus Geat, sextus decimus Tetuua, septimus decimus Beo, octauus decimus Scyld, nonus decimus Scef. Ipse Scef cum uno dromone aduectus est in insula oceani que dicitur Scani, armis circundatus, eratque ualde recens puer, et ab incolis illius terra ignotus. Attamen ab eis suscipitur, et ut familiarem 
diligenti animo eum custodierunt, et post in regem eligunt; de cuius prosapia ordinem trahit Aðulf rex.”

[Assim, rei Æthelwulf morreu após um ano, e seu corpo descansa na cidade de Winchester. O rei citado era filho do rei Ecgbyrht, e seu avô era Ealhmund, seu bisavô Eafa, seu tataravô Eoppa, seu tetravô Ingild, irmão de Ine, rei dos Saxões Ocidentais, que morreu em Roma, e estes reis derivam sua origem de Cenred. Cenred era filho de Ceolwald. Seu avô era Cuthwine, seu bisavô Ceawlin, seu tataravô Cynric, seu tetravô Cerdic, que foi o primeiro a possuir as partes ocidentais da Bretanha após ter derrotado os exércitos dos bretões, e seu pai era Elesa, o avô Esla, o bisavô Gewis, o tataravô Wig, o tetravô Freawine, seu sexto pai Frithogar, o sétimo Brond, o oitavo Balder, o nono Woden, o décimo Frithowald, o décimo primeiro Frealaf, o décimo segundo Frithowulf, o décimo terceiro Fin, o décimo quarto Godwulf, o décimo quinto Geat, o décimo sexto Tetwa, o décimo sétimo Beo(w), o décimo oitavo Scyld, o décimo nono Scef. E este Scef chegou com um barco pequeno na ilha do oceano que é chamada Scane(y), com armas em torno de si, ele ainda um jovem garoto, e desconhecido para o povo daquela terra. Mas ele foi recebido por eles, e acolhido por eles, e o aclamaram rei; e desta família se origina a descendência do rei Æthelwulf. $]^{113}$

Assim como nas Crônicas Anglo-Saxônica, o único relato a respeito de uma linhagem de origem em toda a obra é esta. Entretanto, são claras as diferenças entre as duas versões referentes aos nomes de Beow, Scyld e Scef, além da versão sobre a chegada de Scef numa suposta ilha chamada Skane ou Skaney, onde se torna rei. Antes de tecermos maiores considerações, vamos ver um outro documento do mesmo período. Trata-se de um trecho da Vida do Rei Alfred de Asser.

Asser, monge galês de S. David e que serviu ao rei Alfred tornando-se mais tarde bispo de Sherbone, em sua Vida do Rei Alfred, ao se referir a linhagem do rei ele nos relata o seguinte:

"Sua linhagem é organizada desta forma: Rei Alfred era filho do Rei Æthelwulf, o filho de Egbert, Æthelwulf era o filho de Egbert, o filho de Ealhmund, o filho de Eafa, o filho de Eoppa, o filho de Ingild. Ingild e Ine, o famoso rei dos Saxões do Oeste, eram dois irmãos; Ine viajou para Roma, e honradamente findou esta vida presente lá e entrou na terra celeste para reinar com Cristo. E eles eram filhos de Cenred, o filho de Ceowold, o filho de Cutha, o filho de Cuthwine, o filho de Ceawlin,

${ }^{113}$ CAMPBELL, 1962, pp. 32-33. 
o filho de Cynric, o filho de Creoda, o filho de Cerdic, o filho de Elesa, o filho de Gewis (devido ao qual os galeses chamaram toda aquela raça de gewisse ${ }^{114}$ ), o filho de Brand, o filho de Bældæg, o filho de Woden, o filho de Frithuwald, o filho de Frealaf, o filho de Frithuwulf, o filho de Finn, o filho de Godwulf, o filho de Geat (a quem os pagãos adoraram por muito tempo como um deus), (...) o filho de Tætwa, o filho de Beaw, o filho de Sceldwa, o filho de Heremod, o filho de Itermon, o filho de Hathra, o filho de Hwala, o filho de Bedwig, o filho de Seth, o filho de Noé, o filho de Lamech, o filho de Methuselah, o filho de Enoch (filho de Jared), o filho de Mahalaleel, o filho de Cainan, o filho de Enos, o filho de Seth, o filho de Adão.”115

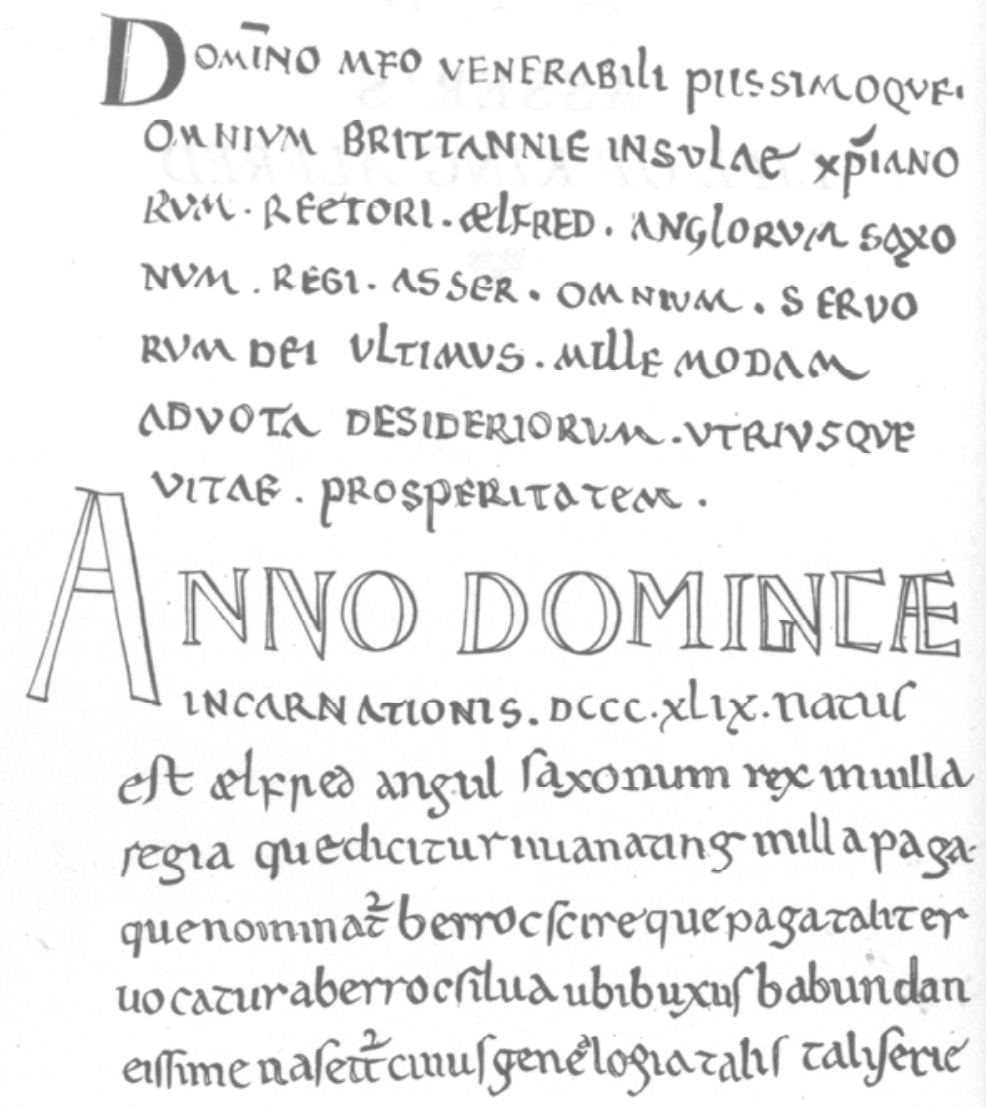

figura 5: Reprodução do inicio da Vida do Rei Alfred, por Asser, do Cotton Otho A XII (c. 1000). Um facssímile do mesmo foi publicado em 1722, poucos anos antes de ser destruído no incêndio do acervo de Sir Cotton. [Simon Keynes, \& Michael Lapidge, (trad. e org.) Alfred the Great: Asser's life of King Alfred and other contemporary sources, Londres: Penguin, 1983, p. 66.]

\footnotetext{
${ }^{114}$ Este é o nome pelo qual Beda se refere aos saxões ocidentais na Historia Ecclesiastica Gentis Anglorum, III.7.

${ }^{115}$ KEYNES \& LAPIDGE, 1983. p. 67.
} 
É interessante observarmos em todas essas linhagens a clara reconstrução de uma ascendência legitimada pelas figuras míticas, ou mito-históricas que as compõe. Pudemos identificar já no primeiro fragmento da Crônica Anglo Saxônica os nomes que estão presentes tanto na Crônica de Æthelweard quanto na Vida do Rei Alfred.

Primeiramente, todas as fontes apresentadas possuem um ponto em comum em sua ascendência a partir de Woden, senão vejamos:

“(...) o filho de Woden, o filho de Frealaf, o filho de Finn, o filho de Godwulf, o filho de Geat, o filho de Tætwa, o filho de Beaw, o filho de Sceldwa, o filho de Heremod, o filho de Itermon, o filho de Hathra, o filho de Hwala, o filho de Bedwig, o filho de Sceaf (...)” - Crônica Anglo Saxônica.

“(...) o nono Woden, o décimo Frithowald, o décimo primeiro Frealaf, o décimo segundo Frithowulf, o décimo terceiro Fin, o décimo quarto Godwulf, o décimo quinto Geat, o décimo sexto Tetwa, o décimo sétimo Beo(w), o décimo oitavo Scyld, o décimo nono Scef (...)” - Crônica de Athelweard.

“(...) o filho de Woden, o filho de Frithuwald, o filho de Frealaf, o filho de Frithuwulf, o filho de Finn, o filho de Godwulf, o filho de Geat (a quem os pagãos adoraram por muito tempo como um deus), (...) o filho de Tætwa, o filho de Beaw, o filho de Sceldwa, o filho de Heremod, o filho de Itermon, o filho de Hathra, o filho de Hwala, o filho de Bedwig, o filho de Seth (...)" - A Vida do Rei Alfred.

Toda esta documentação abrange um período em torno de cem anos, indo de 890 até 980 aproximadamente; e a pergunta que fazemos é: uma vez que estas seriam passagens únicas dentre as demais fontes, por quê ocorreu este acréscimo de ancestrais?

Para começarmos a responder esta pergunta, vamos ver o que essas três principais fontes têm em comum. A Crônica Anglo-Saxônica, apesar de ter sido compilada há tempos, só é organizada e reunida como a conhecemos hoje no governo de Alfred, o Grande. Asser, autor da Vida do Rei Alfred, conviveu com o mesmo. Finalmente, a Crônica de Fthelweard, apesar de ser escrita quase um século após Alfred, é baseada na obra da época, além do próprio Æthelweard fazer parte da casa real de Wessex. Ou seja, o ponto em comum de todas essas narrativas é justamente o rei Alfred, o Grande.

Uma primeira hipótese que podemos levantar é de que era importante para Alfred, e para a casa de Wessex a construção dessa linhagem. Com relação a Woden e os demais, podemos compreender como uma forma de legitimação do poder real por 
meio de um personagem remanescente dos tempos pagãos. Temos a imagem do antigo deus adaptado a uma forma cristianizada, na nova forma de um ancestral nobre legítimo. O que teríamos seria então o interesse da Casa de Wessex (em especial de Alfred e seus descendentes) em vincular sua linhagem com a dos escandinavos, lhes dando prestigio e autoridade sobre seus líderes:

"The evidence of the West-Saxon genealogy shows that the Danish invasions and settlements did not lead Englishmen to dissociate themselves from the Scandinavian heroic age. On the contrary, the heroic North attracted them, and their interest in it permitted them to establish a commom background for comtemporary political and ethic relations.”116

Mas, como já havíamos dito anteriormente, ainda temos as três figuras que se repetem nos relatos. Ora eles são Beaw, Sceldwa e Scef $\left(A S C^{117}\right)$, ora são Beaw, Sceldwa e Seth (LKA), e finalmente Beo(w), Scyld e Scef (CAE); sempre nesta mesma ordem, com algumas variantes de outros nomes que os intercalam, ou juntos como em $C E^{118}$. Tendo em mente as fontes, e estes três personagens, vejamos os seguintes versos de Beowulf:

$$
\begin{aligned}
& \text { Oft Scyld Scefing sceapena preatum } \\
& \text { monegum mægpum meodo-setla ofteah, } \\
& \text { egsode eorlas, syððan ærest wearð } \\
& \text { feasceaft funden; he pæs frofre gebad: } \\
& \text { weox under wolcnum, weorð-myndum pah, } \\
& \text { oðpæt him æghwylc para ymb-sittendra } \\
& \text { ofer hron-rade hyran scolde, } \\
& \text { gomban gyldan. p pæt wæs god cyning. }
\end{aligned}
$$

\footnotetext{
${ }^{116}$ MURRAY, 1997, p. 105: "A evidência da genealogia dos saxões-ocidentais mostra que as invasões dinamarquesas e assentamentos não levou os ingleses a se dissociarem da era heróica da Escandinávia. Pelo contrário, o norte heróico os atraía, e seu interesse nele os permitiu estabelecer um passado comum para a política contemporânea e relações éticas".

${ }^{117}$ ASC - Crônica Anglo Saxônica; LKA - Vida do Rei Alfred; CÆ - Crônica de Æthelweard.

${ }^{118}$ STENTON, 1989, p. 335: Dentro do poema, há também uma suposta referência a um rei Offa. Há uma teoria de que o Offa citado em Beowulf fosse uma referencia ao rei Offa de Mercia. Mas devemos nos perguntar: se o que temos em Beowulf seria um reflexo de um período de hegemonia da casa de Wessex, qual seria a razão para tal passagem vinculando o poema a Mercia? A resposta poderia ser devido a esposa de Alfred, Ealhswith. Ealhswith era da linhagem da casa real de Mercia, e desta forma, descendente do rei Offa. Desta forma, seguindo nossa hipótese, os descendentes de Alfred e Ealhswith poderiam reclamar sua descendência tanto de Æthelwuf até Scef e Scyld, como também de Offa. De fato, Æthelflæd, filha de Alfred, governou Mercia até 918, sendo sucedida por seu sobrinho Athelstan (que havia sido criado em Mercia, e é aceito como rei antes mesmo do que em Wessex). Como diz Stenton: "the first king of Wessex who was intimate with the Mercian aristocracy was brought up in the household of Æthelflæd and her husband Ealdorman Æthelred”..
} 


\begin{abstract}
Đaem eafera wæs æfter cenned
geong in geardum pone God sende

folce to frofre; fyren-ðearfe ongeat,

pæt hie ær drugon aldor-lease

lange hwile; him pæs Lif-frea,

wuldres Wealdend, $\quad$ worold-are forgeaf;

Beowulf wæs breme - blæd wide sprang -

Scyldes eafera, Scede-landum in.
\end{abstract}

[Por vezes Scyld Scefing de tropas inimigas, / de muitas tribos, tomou os salões; / ele aterrorizou guerreiros, mesmo que a principio fosse / encontrado sozinho. Mas para isto veio uma solução, / ele prosperou sob os céus, obteve grande honra / até que cada uma das nações ao longo da costa, / além do caminho-da-baleia, se submetessem / e lhe pagassem tributo. Ele foi um bom rei! / Eis que ele teve um filho, / jovem na corte, que Deus enviou / para confortar seu povo; um grande sofrimento lhes abatia / por eles terem permanecido sem um líder / por tanto tempo. Assim, o Senhor da Vida, / o Regente da Glória, lhe concedeu grande renome. / Beowulf foi famoso - seu nome se espalhou ao longe - / o filho de Scyld, por todas as terras do Norte.]

(Beowulf vv. 4 - 19.)

É muita clara a relação das fontes com o poema. Dentro destes versos estão justamente as três figuras que identificamos nos documentos. Em Beowulf, estes primeiros versos apresentam a linhagem da dinastia dos reis dinamarqueses: Scyld Scefing (ou seja, Scyld filho de Scef), e seu filho Beow (ou Beowulf). Assim, nós podemos estabelecer a seguinte relação:

$\begin{array}{llll}\text { ASC } & \text { LKA } & \text { CA } & \text { Beowulf } \\ \text { Scef } & \text { Seth } & \text { Scef } & \text { Scef } \\ \text { Sceldwa } & \text { Sceldwa } & \text { Scyld } & \text { Scyld } \\ \text { Beaw } & \text { Beaw } & \text { Beo(w) } & \text { Beow/Beowulf }\end{array}$

Esta relação, ou identificação das fontes com o poema, fica mais forte ainda se compararmos a Crônica de Athelweard com Beowulf no que se refere à história da origem de Scef: 
"E este Scef chegou com um barco pequeno na ilha do oceano que é chamada Scane(y), com armas em torno de si, ele ainda um jovem garoto, e desconhecido para o povo daquela terra. Mas ele foi recebido por eles, e acolhido por eles, e o aclamaram rei (...)”- Crônica de Athelweard.

$\begin{aligned} & \text { Him ða Scyld gewat to gescæp-hwile, } \\ & \text { fela-hror, feran on Frean wære. } \\ & \text { (...) }\end{aligned}$
Nalæs hi hine læssan lacum teodan,
peod-gestreonum, pon pa dydon
pe hine æt frumsceafte forð onsendon
ænne ofer yðe umbor-wesende.

[Scyld então partiu quando sua hora chegou,/ ainda cheio de vigor, para junto dos cuidados do Senhor. (...) Não menos foram os presentes que lhe ofertaram / - o tesouro de um povo - do que os que foram dados / por aqueles que primeiramente o haviam mandado embora, / e o lançado sozinho através das ondas quando criança.] (Beowulf vv. 26-27, $43-46$ ).

O que podemos retirar disso seria que a casa de Wessex tinha conhecimento de Beowulf. Sua proximidade com a aristocracia da Danelaw os fizeram ter também uma ascendência escandinava, uma vez que durante o século $\mathrm{X}$ eles passam a governar a Inglaterra como um todo, tanto saxões quanto escandinavos, principalmente no governo do rei Athelstan.

Nossa segunda hipótese então seria de que Beowulf teria sido composto justamente no século X. Para tal, vamos averiguar os elementos favoráveis para que isto pudesse ter ocorrido. Um dos primeiros fatores favoráveis a essa hipótese, seriam as referências, já mencionadas anteriormente, das crônicas e da Vida de Alfred e a ascensão de Wessex. Além disso, o período que os documentos abrangem (890 a 980) está fora dos grandes ataques vikings e crises. Este é um momento de relativa ordem dentro da Inglaterra, basta pegarmos o exemplo do governo de Edgar, pai de Æthelred II, que teria até mesmo reduzido o contingente militar do reino por ser desnecessário a manutenção de um grande exército. E este também é um período mais propício e harmonioso para o estreitamento das relações com as povoações da Danelaw. 
Este período também se torna ideal para um fortalecimento da imagem heróica. Exemplo disso seriam produções semelhantes em ambiente e, talvez, gênero, como os poemas da Batalha de Brunambuhr (em 937), bem dentro do período, e a Batalha de Maldon (em 991), já no final deste período. A principio, o que estamos mostrando, é que não nos apoiamos na idéia de que as origens de Beowulf estão em Wessex ou se ele foi utilizado talvez de forma política em relação a Danelaw; o que importa nesse momento é este ser um período propício para os elementos do poema fazerem sentido e terem significado. E isto talvez tenha se dado de forma mais completa no governo de Athelstan, como sendo o período mais importante dentro da ascensão e hegemonia de Wessex.

\section{Gráfico 1: Evolução do poema Beowulf.}

\begin{tabular}{c|l} 
Séc. VII - VIII & $\begin{array}{l}\text { Relatos e fontes do continente (do período } \\
\text { das migrações) que poderão vir a se tornar } \\
\text { Beowulf. }\end{array}$ \\
Séc. IX & $\begin{array}{l}\text { Construção da narrativa } \\
\text { (influência escandinava). }\end{array}$ \\
Séc. XI & $\begin{array}{l}\text { Forma atual ou próxima ao } \\
\text { manuscrito existente (influência } \\
\text { escandinava). }\end{array}$ \\
Compilação do manuscrito \\
existente.
\end{tabular}

Para exemplificar nossa hipótese desenvolvemos o quadro cronológico acima, segundo o qual, os relatos e referências que servirão para a construção do poema, muito provavelmente já existiriam nos séculos VII e VIII. Talvez até mesmo na Northumbria, já nos tempos de Beda. Mais tarde, no século IX, esses elementos tomam forma e sofrem alterações e adaptações nos reinos de Mercia e Anglia Oriental. Chegamos ao 
século X com o ambiente adequado para que o poema tenha uma forma próxima ou até mesmo semelhante ao que conhecemos hoje; e finalmente, no século XI, o poema é compilado, talvez entre os governos de Æthelred II e Cnut.

Após Alfred, o Grande até a ascensão de Æthelred II temos então um período de ascensão e hegemonia de Wessex. Edward, o Velho foi quem deu início a esse momento, ao ter sua soberania assegurada em Wessex, Mercia Ocidental e a reconquista de regiões da Danelaw. Mesmo assim, teve de enfrentar certos problemas políticos em Mercia, além do reino de York. Edward I, o Velho, até o final de seu governo, havia submetido todas as regiões ao sul do rio Humber, ainda em poder dos vikings, sob sua autoridade. Entretanto, houve ainda diversos conflitos contra os vikings, mas nenhum de proporções tão grandes quanto os enfrentados por eu pai. Um dos primeiros conflitos surgiu dentro da própria casa de Wessex. Liderados por Æthelwold, (primo de Edward, o Velho), um grupo de viking realizou ataques contra Wessex durante 899 e 902. Eles acabam sendo derrotados, mas em 909 novos conflitos contra os vikings recomeçam. Entretanto, um elemento importante para o segurança do poder de Edward foi o apoio que obteve de Mercia, principalmente após a morte de seu rei, Æthelred de Mercia, e a ascensão de sua esposa: Æthelflæd, “Senhora dos mercios”, irmã de Edward I. É possível que mesmo antes da morte de Æthelred, Æthelflæd já desempenhava um papel importante dentro do governo de reino. Segundo Sir Frank Stenton ${ }^{119}$, nos registros do reino de Mercia, já em torno de 901, é possível vermos que Æthelred não estivesse participando mais das campanhas contra os vikings, indicando que ele estaria de certa forma já incapacitado pouco antes de sua morte.

O apoio de Mercia, sob a liderança de Æthelflæd, foi fundamental para assegurar a força dos saxões frente aos vikings, e para o poder do governo de Edward I. Mais tarde, com a morte de sua irmã em 917, Edward viria a ter problemas com a aristocracia de Mercia, que pela primeira vez desde há muito tempo, possuía certa autonomia para estabelecer relações com quem quisesse. Isto trouxe um clima de insegurança dentro da política de Edward I, visto que isso poderia trazer uma quebra da aliança entre os dois reinos. Entretanto, este problema foi solucionado em 919 com a captura de Ælfwynn. Era desejado dentre estes aristocratas alguém que os representasse, e para tal função havia sido escolhida a filha de Æthelflæd. Mas, como já dissemos, Edward I pôs fim a esta “autonomia” de Mercia ao capturar sua sobrinha, destituí-la do poder entregue a ela

${ }^{119}$ STENTON, 1989, p. 324. 
pela aristocracia de Mercia, e assumindo a autoridade sobre o reino que passou a ser uma parte integrante de Wessex, com a aprovação dos antigos seguidores de Æthelflæd.

Com a submissão de Mercia, foi possível a Edward I uma maior aproximação aos reinos galêses. Desde os tempos de Alfred que havia alianças entre Wessex e os reinos galeses, diferente do que ocorria em relação a Mercia. Já desde os tempos do rei Offa que o relacionamento entre Mercia e os galeses não era amistoso ${ }^{120}$. Alfred teria auxiliado os galeses, e seus príncipes teriam se submetido a ele em troca de proteção contra Æthelred de Mercia ${ }^{121}$; e seus sucessores estiveram extremamente dispostos a manter essa aliança ao reconhecer a autoridade de Edward $\mathrm{I}^{122}$. Desta forma, com o apoio de Mercia e dos reinos de Gales, Edward I possuía força o suficiente para enfrentar as colônias escandinavas que ainda resistiam ao sul do rio Humber.

Com o tempo, Edward I submeteu as antigas colônias escandinavas. O ponto alto de seu governo foi justamente o acordo realizado no norte da Inglaterra, em torno de 923, segundo a Crônica Anglo-Saxônica. Segundo o registro, nesse ano Edward I foi até Bakewell, região de Derbyshire, e lá se encontrou com Constantino, rei dos escoceses, e com Rægnald, que a pouco tempo havia tomado o reino de York, Ealdred de Bamburgh, e também o rei de Strathclyde. O resultado deste encontro foi a submissão de todos a Edward I. A razão para tal atitude dos mesmos frente ao rei de Wessex seria porque: Ealdred, em meio a bretões, escoceses e escandinavos, teria a segurança da proteção do mais poderoso rei da Inglaterra; para Rægnald era interessante pois em troca teria o reconhecimento de Edward I de sua autoridade como rei de York; o rei de Strathclyde teria a confirmação de suas terras que seu povo havia anexado da Northumbria; já para Constantino, teria obtido uma certa segurança, mesmo que temporária, contra os ataques de Rægnald e de seus aliados vikings na Irlanda. Este acordo não era apenas vantajoso para Edward I, mas também promoveu um avanço na consolidação da hegemonia de Wessex sobre a Inglaterra. Ao final de seu governo, Edward I, o Velho era responsável por ter estendido as fronteiras do reino que Alfred havia lhe deixado, tendo assim um reino duas vezes maior que o de seu pai. Edward I conseguiu manter o reino em equilíbrio, apesar da fraca autoridade que possuía no

\footnotetext{
${ }^{120}$ Haja visto a construção do Offa's Dyke; uma barreira de 103 km, construída, segundo Asser “ (...) de mar a mar (...)”, separando as terras de Gales da Inglaterra, construído pelo rei Offa como uma medida militar contra os galeses.

${ }^{121}$ KEYNES \& LAPIDGE, 1983. p. 96.

${ }^{122}$ STENTON, 1989, p. 330.
} 
norte, em especial no reino viking de York (principalmente com a morte de Ræagnald, e a ascensão de seu primo Sithric, que nunca reconheceu a autoridade de Edward I).

Edward I morreu em 924, sendo sucedido por seu filho Athelstan, que teria sido aclamado rei tanto em Wessex quanto em Mercia, visto que ele teria sido criado na corte de Æthelred e Æthelflæd. O fato de sua criação em Mercia, fez com Athelstan possuísse uma relação muito mais próxima com a aristocracia local, do que seu pai tinha; e seu reconhecimento como rei em Mercia teria sido absolutamente independente do ocorrido em Wessex.

Logo após sua coroação, Sithric, rei de York, diferente do posicionamento tomado com Edward I, propõe uma aliança a Athelstan; e logo depois a irmã de Athelstan é enviada a York como sua noiva. Entretanto, no ano seguinte, Sithric morre (em 927), deixando uma viúva e um filho chamado Olaf, que é imediatamente aclamado como novo rei pelos escandinavos. Ao mesmo tempo, o irmão de Sithric, Guthfrith, rei de Dublin, chega à Inglaterra para se unir a seu sobrinho. Como resposta, Athelstan invade a Northumbria, e após uma breve campanha, expulsa Olaf e Guthfrith do reino. Além disso, Athelstan decide reforçar sua posição entre os lideres do norte da Inglaterra.

Ao lermos a Crônica Anglo-Saxônica, referente ao ano de 926-927, nos parece ter sido o segundo momento mais importante do governo de Athelstan, depois de 937 com a batalha de Brunanburh:

“926. (...) E Sithric pereceu e o rei Athelstan o sucedeu no trono da Northumbria; e ele governou todos os reis que estavam nessa ilha: primeiro Hywel, rei dos galeses do oeste, e Constantino, rei dos escoceses, e Owain, rei de Gwent, e Ealdred, da linhagem de Ealdwulf, de Bamburgh. E eles afirmaram a paz com promessas e juramentos em um lugar que é chamado Eamont, em 12 de julho (...)”."123

Desta forma, podemos ver que o poder de Athelstan sobre a Inglaterra parece estar muito mais consolidado do que havia sido com seu pai. Como exemplo disso, podemos ver a influência sobre os reis galeses. Entre 931 e 937, por diversas vezes eles estiveram na corte de Athelstan, inclusive aparecendo como testemunhas em um de seus ofícios de 934, referente a Sé em York ${ }^{124}$. Neste documento, encontramos entre suas testemunhas o rei Hywel de Dyfed, rei Idwal de Gwynedd e o rei Morgan de

\footnotetext{
123 SWANTON, 1997, p. 107.

${ }^{124}$ WHITELOCK, 1955, pp. 505-506.
} 
Morgannwg. É interessante observarmos a denominação utilizada para eles: “sub-rei”, indicando assim sua submissão à autoridade de Athelstan ${ }^{125}$.

Através disso podemos ver que desde Alfred, progressivamente Wessex despontava como uma liderança dentro da Inglaterra que aos poucos vai se expandindo e absorvendo todas as populações da região sem exceção: bretões, anglo-saxões e escandinavos. Edward I dá prosseguimento às ações de seu pai, mas é com Athelstan que a expansão de Wessex se dá de forma mais clara e abrangente. Desta forma, chegamos ao momento mais critico e importante para o governo de Athelstan, e também para os anos seguintes da história da Inglaterra anglo-saxônica, com o advento da lendária batalha de Brunanburh.

Voltemos mais uma vez à Crônica Anglo-Saxônica. Segundo seus registros, após o acordo de 926-927, com a tomada de York e o acordo realizado entre os líderes do norte, não houve grandes problemas para Athelstan até 933-934. Possivelmente em resposta a alguma ação ofensiva por parte do rei Constantino, Athelstan realiza um grande ataque a Escócia por terra e mar. É interessante notarmos mais um fato que demonstra a unidade que o governo de Athelstan havia atingido. Dentre os líderes do exército que avançava por terra, se encontrava um grande número de thegns saxões, quatro príncipes galeses, e doze earls (sendo que em torno de cinco deles possuíam nomes escandinavos, e com certeza vinham dos territórios da Danelaw) ${ }^{126}$. Ao que parece, o rei escocês não ofereceu resistência, e o exercito de Athelstan invadiu o território escocês enquanto sua frota atacava a costa. Apesar desta vitória, e do acordo feito anos antes, as terras do norte, em especial Escócia e Strathclyde eram ainda um ponto fraco no poder Wessex na Inglaterra.

Em torno de 934 Dublin possui um novo rei, Olaf Guthfrithson. Seu pai era o mesmo Guthfrith que anos antes havia sido expulso da Inglaterra por Athelstan, pela disputa pelo reino de York. Uma vez rei dos vikings do leste irlandês, Olaf organizou uma enorme frota na costa da Irlanda, tendo por objetivo retomar as terras na Inglaterra que haviam sido tomadas de sua família. Imediatamente os reinos de Strathclyde e da Escócia se aliaram a ele, fazendo frente ao avanço do domínio inglês. Em 937, Olaf Guthfrithson partiu com sua frota para a Inglaterra, e assim que chegou, uniu-se ao

\footnotetext{
${ }^{125} \mathrm{~A}$ influência anglo-saxônica sobre Gales pode ser visto, por exemplo, na figura do rei Hywel de Dyfed. Hywel teria dado nomes saxônicos a seus filhos, produzido moedas de prata ao estilo saxão e também teria adotado a imagem anglo-saxônica do rei como legislador. Não sabemos de outro rei galês que tenha demonstrado tamanha influência, apesar de todos eles estarem sob esta nova influência da esfera política anglo-saxã.

${ }^{126}$ STENTON, 1989, p. 342.
} 
exercito de seus aliados e iniciaram seu avanço sobre o território inglês. Após um grande avanço reino adentro, eles finalmente foram confrontados com o exército de Athelstan. Sob a liderança de Athelstan e de seu irmão Edmund, os invasores foram massacrados onde, segundo alguns registros, chamava-se Brunanburh ${ }^{127}$. Na Crônica Anglo-Saxônica, a passagem do ano de 937 a respeito da batalha está inteiramente em versos aliterativos, o mesmo estilo de Beowulf ${ }^{128}$ :

Her Æðelstan cyning, eorla dryhten, beorna beaggiefa, and his broðor eac

Eadmund æðeling, ealdorlangne tir geslogon æt sæcсе sweorda ecgum ymbe Brunanburh. Bordweall clufon, heowon heaðulinda hamora lafum eaforan Eadweardes, swa him geæðele wæs

fram cneomagum

wip laðra gehwone pæt hie æt campe oft

hord and hamas.

land ealgodon,

Hettend crungon,

Scotta leode and scipflotan,

fæge feollon. Feld dennode

secga swate, sippan sunne upp

on morgentid, mære tungol,

glad ofer grundas, Godes candel beorht, eces Dryhtnes, op seo æðele gesceaft

sag to setle. $\quad$ ær læg secg manig garum agieted, guma Norðerna

ofer scield scoten, swelce Scyttisc eac, werig, wiges sæd. West-Seaxe forp andlangne dæg eorodcystum

on last legdon laðum peodum,

heowon hereflieman hindan pearle

mecum mylenscearpum. Mierce ne wierndon
Aqui o rei Athelstan, líder dos nobres, doador-de-anéis aos homens, e também seu irmão, o príncipe Edmund, glória por toda a vida obtiveram em batalha com a ponta de suas espadas

5 em Brunanburh. Romperam a muralha-de-escudos, destruíram os escudos de madeira a golpes de martelo os filhos de Edward, assim como era natural a eles por seus ancestrais que por muitas vezes em combate contra os inimigos defenderam sua terra,

10 tesouros e lares. Os inimigos caíram, o povo dos escoceses e os homens-do-mar, condenados tombaram. O campo encharcado com o sangue dos guerreiros, depois que o sol se ergueu ao amanhecer, esplendida estrela,

15 movendo-se sobre o solo, brilhante vela de Deus, o Senhor eterno, até que aquela nobre criação mergulhasse em seu descanso. Lá tombaram muitos guerreiros mortos por lanças, homens-do-norte atingidos por cima de seus escudos, como também os escoceses, cansados, fatigados da batalha. Os saxões-do-oeste continuaram por todo o dia com sua tropa de elite no encalço da hoste inimiga, massacrando os fugitivos pela retaguarda intensamente com suas espadas afiadas. Os mercios não se recusaram

\footnotetext{
${ }^{127}$ Na Crônica de Æthelweard, o local é chamado Brunandun; Simeon de Durham o chama de Wendun; enquanto Florence de Worcester diz apenas que Olaf teria entrado pela foz do Humber. De qualquer forma, o local da batalha nunca foi identificado com precisão.

${ }^{128}$ A passagem do ano de 937 com o poema é encontrada em todas as versões da Crônica AngloSaxônica, com exceção das versões E e F, sendo que esta última tem metade da página em branco no local da passagem e depois um breve registro em prosa. Talvez o espaço tenha sido deixado para o poema? De qualquer maneira, existem outras passagens em versos aliterativos na Crônica AngloSaxônica, respectivamente nos anos de 942, 973, 975, 1036, 1065. É interessante observarmos que, o período que abrange os registros em versos, é justamente o de maior possibilidade para a construção da narrativa de Beowulf, segundo nossa hipótese. Ou seja, um período mais fértil a produções, no caso poéticas, de exaltação do ideal heróico, do caráter aristocrático e da imagem real.
} 
heardes handplegan

hæleða nanum

parape mid Anlafe

ofer eargebland

on lides bosme land gesohton,

fæge to gefeohte. Fife lagon

on pæm campstede cyningas geonge,

sweordum aswefede, swelce seofone eac

eorlas Anlafes, unrim herges,

flotena and Scotta. $\quad$ bær gefliemed wearp

Norpmanna bregu, niede gebæded,

to lides stefne lytle weorode;

cread cnearr on flot, cyning ut gewat

on fealone flod, feorh generede.

Swelce pær eac se froda mid fleame com

on his cyppe norb, Constantinus,

har hilderinc. Hreman ne porfte

meca gemanan; he wæs his maga sceard,

freonda gefielled on folcstede,

beslægen æt sæcce, and his sunu forlet

on wælstowe wundum forgrunden,

geongne æt guðe. Gielpan ne porfte

beorn blandenfeax billgesliehtes,

eald inwidda, ne Anlaf by ma;

mid hira herelafum hliehhan ne porfton

pæt hie beaduweorca beteran wurdon

on campstede cumbolgehnastes,

Garmittinge, gumena gemotes,

wæpengewrixles, bæs hie on wælfelda

wip Eadweardes eaforan plegodon.

Gewiton him pa Norpmenn nægledcnearrum,

dreorig daroða laf, on Dinges mere

ofer deop wæer Dyflin secan,

eft Iraland, æwiscmode.

Swelce pa gebroðor begen ætsamne,

cyning and æðeling, cyppe sohton,

West-Seaxna land, wiges hremige.

Leton him behindan hræw bryttian

salwigpadan, pone sweartan hræfn,

hyrnednebban, and pone hasupadan,

earn æftan hwit, æses brucan,
25 a um duro combate desarmado com qualquer homem que com Olaf sobre a turbulência do mar no fundo de um barco chegaram em terra, condenados a lutar. Cinco pereceram naquele campo-de-batalha dos jovens reis,

30 postos para dormir por espadas, assim também sete dos jarls de Olaf, incontável número do exército, dos marinheiros e escoceses. Lá ocorreu de ter de lutar o senhor dos homens-do-norte, compelido por necessidade, para a proa da embarcação com uma pequena tropa;

35 apressou o barco para o mar, e o rei partiu nas correntezas escuras, para salvar sua vida.

Da mesma forma lá também o velho com rapidez foi para seu lar no norte, Constantino, o grande guerreiro. Não tinha porque exaltar

40 o confronto de espadas; ele foi privado de seus parentes, seus amigos mortos no campo-de-batalha, derrotado em combate, e deixou seu filho no local da matança destruído pelos ferimentos, jovem em batalha. Orgulhar-se não precisava

45 o homem grisalho da matança pelas espadas, velho adversário, muito menos Olaf;

com os remanescentes de seu exército não havia o que comemorar

por eles serem melhores em feitos de guerra

no campo-de-batalha e no choque dos estandartes,

50 no conflito das lanças, na reunião dos homens, no confronto-de-armas, pois eles neste campo-de-batalha lutaram contra os filhos de Edward.

Partiram então os homens-do-norte em seus barcos-longos, sanguinários sobreviventes de lanças, para Dingesmere,

55 sobre as águas profundas rumo a Dublin, de volta a Irlanda, envergonhados.

Assim como irmãos unidos, rei e príncipe, foram para seus lares, a terra dos saxões-do-oeste, exultantes pelo combate.

60 Eles deixaram para trás para dividir os cadáveres o de plumagem-escura, o corvo negro, o de bico-agudo, e de penas-acinzentas, a águia de cauda branca, para se deliciar com a carnificina, 
grædigne guphafoc and pæt græge deor,

wulf on wealda. Ne wearp wæl mare

on pys ieglande æfre gieta

folces gefielled beforan pissum

sweordes ecgum, p bespe us secgap bec,

ealde upwitan, sippan eastan hider

Engle and Seaxe upp becomon,

ofer brad brimu Breotone sohton,

Wlance wigsmiðas, Wealas ofercomon,

eorlas arhwæte eard begeaton. o cobiçoso falcão-guerreiro e a fera cinzenta,

65 o lobo da floresta. Nunca havia ocorrido tamanha matança nesta ilha até hoje de um exercito perecer antes disso pela ponta da espada, assim como nos conta os livros, os velhos sábios, antes que do leste para cá

70 anglos e saxões viessem, sobre o grande mar buscando a Bretanha, valorosos guerreiros, subjugaram os galeses, gloriosos heróis que conquistaram esta terra.

A batalha de Brunanburh possui uma importância decisiva para aquele momento da história da Inglaterra. Ela não possui o mesmo peso que outras batalhas do passado inglês, isso se comparada aos conflitos ocorridos nos governos de Edward I e Alfred, o Grande no que diz respeito a uma ameaça estrangeira contra o reino. Entretanto, em Brunanburh, o processo de expansão do domínio político de Wessex, que se iniciou com Alfred, é finalmente concluído. Com esta vitória em 937, Athelstan se tornava finalmente senhor de toda a Inglaterra ${ }^{129}$. Dentre os reis saxões, o governo de Athelstan foi um dos mais importantes dentro do período, e um dos mais prováveis para a construção da narrativa de Beowulf.

Com sua vitória em Brunanburh, a hegemonia de Wessex, ao menos durante seu governo, estava assegurada. Para termos uma idéia mais geral da influência de Athelstan no período, vamos observar, por exemplo, sua relação com outros reinos além das Ilhas Britânicas. Desde os tempos de Alfred, o Grande que a corte inglesa mantinha ligações com o continente, principalmente com a corte carolíngia. Entretanto, vai ser nos tempos de Athelstan que essas conexões com reinos estrangeiros se dará de forma mais abrangente. Athelstan mantém suas ligações políticas com os carolíngios, mas também estabelece alianças com os germânicos ${ }^{130}$, e até mesmo com o rei Harald da Noruega; e prova dessa aliança se deposita no nome do rei Harald: Hakon Aðalsteinfóstri, ou seja “filho adotivo de Athelstan”. Ao que parece o filho do rei Harald teria sido enviado a corte de Athelstan onde foi criado. Tal grau de influencia política só se repetirá na Inglaterra no período pós-Conquista normanda.

\footnotetext{
${ }^{129}$ STENTON, 1989, p. 343: "In the fighting around Brunanburh Athelstan was defending a state which embraced the decendants of Alfred's Danish enemies, and a civilization which united them to Christian Europe."

${ }^{130}$ Athelstan teria enviado uma de suas irmãs como noiva para Oto I.
} 
Enquanto isso, a imagem do poder real anglo-saxônico é consolidada através de Athelstan. Ele realmente cria a imagem do soberano de toda a ilha. Em uma de suas moedas, ele é descrito como "rei de toda a Bretanha"; em alguns de seus documentos oficiais, ele é citado como "rei dos ingleses e senhor de toda a Bretanha", ou ainda "rei dos ingleses, elevado ao trono do reino da Bretanha pela mão direita do TodoPoderoso" "131. Aliás, este tipo de relação entre a imagem do rei e as palavras usadas para se referir a ele são um traço conhecido dos documentos de Athelstan. Temos por exemplo a utilização de termos como monarchus, basileus, curagulus e imperator. Não poderíamos dizer que se tratasse de uma chancelaria, mas é sabido que a responsabilidade pela produção de tal documentação, era de clérigos altamente treinados na arte deste estilo de escrita, e que acompanhavam o rei para onde quer que ele fosse. Justamente nesse âmbito, nos chama a atenção uma passagem de um de seus documentos pessoais, onde podemos identificar novamente não apenas a admiração de Athelstan por palavras de efeito para a denominação do título real, mas também algo que reflete um pouco da política e da sociedade do momento. Este documento teria sido composto em New Minster, em Winchester, mas não podemos precisar se antes ou após Brunanburh, onde encontramos a seguinte denominação: Angelsaxonum Denorumque gloriosissimus rex ${ }^{132}$. A primeira coisa a nos chamar a atenção é a utilização do termo Angelsaxonum. Este seria um dos primeiros documentos que se tem conhecimento a utilizar tal expressão, ao invés de se referir apenas aos saxões ou aos anglos de forma diferenciada, pratica adotada muito provavelmente a partir do governo de Alfred, o Grande $^{133}$. Além disso, também nos chama a atenção o fato da menção referente aos escandinavos: Denorumque. Até então não havia necessariamente, nenhuma referência oficial às populações escandinavas na Inglaterra. O que temos aqui então, seria talvez a imagem exata do governo de Athelstan; onde anglo-saxões e escandinavos estariam num mesmo patamar, como súditos do mesmo rei dentro de uma Inglaterra unida. Entretanto, de que outra forma poderíamos averiguar essa suposta unidade dentro do reino de Athelstan, além de uma referência a uma titulação real? Nos documentos oficiais de seu governo.

${ }^{131}$ STENTON, 1989, p. 349.

${ }^{132}$ STENTON, 1989, p. 353.

${ }^{133}$ Na obra de Asser, sobre a vida do rei Alfred, o Grande, o termo utilizado é: Angul Saxonum rex. Termo relacionado às populações que em torno de 886 não estavam sob o jugo dos escandinavos. O que é reforçado pela introdução de Vida do Rei Alfred, onde Asser também se refere a ele como "Alfred, soberano de todos os cristãos da ilha da Bretanha, rei dos anglos e saxões”. Antes disso, os termos mais comuns entre os reis de Wessex seriam apenas rex Saxonum, rex Westsaxonum ou ainda rex Occidentalium Saxonum. Ver KEYNES \& MICHAEL, 1983, pp. 227-228. 
Com base nos documentos do período (não apenas de Athelstan, mas também de seus sucessores), podemos notar a presença de escandinavos entre os oficiais do rei Athelstan, Edmund, Eadred e Eadwig. Vemos que por um período em torno de trinta e cinco anos, os escandinavos faziam parte do governo inglês. Em um documento de Athelstan (circa 934) sobre uma doação de terra para a arquidiocese de York (citado anteriormente), podemos contar entre as testemunhas que assinam o ofício com o próprio rei Athelstan; Wulfhelm, arcebispo de Canterbury; Wulstan, arcebispo de York; com os reis galeses (aqui denominados, como já dissemos, como sub-reis) Hywel, Morgan e Idwal; com a presença de 16 bispos, 7 nobres anglo-saxões, 11 oficiais do rei (thegns), e 6 nobres escandinavos: Ragnald, Ivar, Hadder, Scule, Thurferth, Halfden. É claro que estes nobres de nomes escandinavos seriam oriundos dos territórios da Danelaw $^{134}$. Em outro documento, este já datado de cerca de 946, sobre a doação de terras em Warkton, Northamptonshire, a um homem chamado Wulfric pelo rei Eadred, encontramos o seguinte elenco de testemunhas: o rei Eadred; 2 arcebispos de nome Oda e Wulfstan (provavelmente arcebispo de York); 6 bispos; 4 clérigos; os nobres galeses Hywel, Morgan e Cadmo; 5 nobres anglo-saxões; e 4 nobres escandinavos de nome Orm, Morcar, Grim e Coll; além de mais 4 abades $^{135}$. Já em outro documento de 956, referente às terras de Southwell para o arcebispo de York, vamos ter entre as testemunhas: o rei Eadwig; príncipe Edgar, irmão de Eadwig; os arcebispos Oda e Oscetel, arcebispo de York; 6 bispos; 8 nobres anglo-saxões; 16 oficiais do rei; e 3 nobres escandinavos: Gunner, Orm e Leot ${ }^{136}$. Já após Eadwig não iremos encontrar mais nomes escandinavos na documentação. Mas, ao observarmos o exemplo acima, veremos que o auge da presença dos escandinavos foi justamente no governo de Athelstan, e com seus irmãos essa presença vai diminuindo até desaparecer. Entretanto, apesar de não aparecerem mais nos ofícios reais, ainda vamos encontrar a presença dos escandinavos nas leis do período.

Com relação às leis, podemos verificar a presença escandinava também. Isso pode ser verificado nas leis de Alfred, o Grande (em especial no tratado de 886-890, realizado com o líder viking Guthrum, onde foram definidas as fronteiras da Danelaw e demais políticas entre anglo-saxões e escandinavos), que ainda estavam vigentes nos tempos de Athelstan. Apesar da falta de referencia da presença escandinava nos ofícios

\footnotetext{
${ }^{134}$ WHITELOCK, 1955, pp. 505-508.

${ }^{135}$ WHITELOCK, 1955, pp. 508-509.

${ }^{136}$ WHITELOCK, 1955, pp. 512-514.
} 
de Edgar, em suas leis podemos encontrar passagens claras disso, em especial no códice de Wihtbordesstan (IV Edgar, 962-963). Dentro desse códice, em especial os parágrafos 2.1; 12 e 15. Essencialmente, estes três parágrafos permitem aos escandinavos viverem em seu território sobre suas próprias leis, uma vez que demonstraram sua lealdade pelo rei Edgar. O que temos então é uma convivência entre anglo-saxões e escandinavos, regulamentada por leis desde o final do século IX até meados do século X. Devemos estar atentos para um ponto importante, que é a forma como se dava a rivalidade entre anglo-saxões e invasores. Dentro da documentação da Era Viking, a forma pela qual os vikings são muitas vezes tratados é "pagãos”. Ou seja, apesar de existir o termo específico para eles (Dane, Dani, Dene), o que causa maior estranhamento aos anglosaxões é o fato deles serem pagãos e não deles serem escandinavos. O que temos é uma diferença, um confronto, no campo religioso e não territorial. Não era visto como um confronto entre escandinavos e anglo-saxões, mas sim entre cristãos e pagãos. Sendo assim, não seria de todo estranho uma casa real saxã (como Wessex) possuir entre seus ancestrais escandinavos (no caso dinamarqueses) como aparece em Beowulf e na genealogia do rei Æthelwulf, pois eles eram cristãos: os scyldings, rei Hrothgar, Beowulf, Hygelac e etc. são escandinavos, mas são cristãos que louvam o Ece Dryhten (“Senhor Eterno”), o “Monarca Celeste”. Isso os faz figuras diferentes dos pagãos que encontramos em relatos como os de Alcuino de York, e enfraquece a teoria de Dorothy Whitelock da impossibilidade de uma datação para o poema Beowulf após o ano 835; o que possibilita nossa hipótese de uma datação no período alfrediano, mais especificamente no governo do rei Athelstan ${ }^{137}$.

Recapitulando alguns elementos que apontamos como: as referências das construções de uma ancestralidade mito-histórica, a repetição de certos nomes ou personagens dentro dessa linhagem; o advento da expansão do poder de Wessex sobre o território inglês a partir de Alfred, o Grande e atingindo seu auge no governo de Athelstan; o próprio governo de Athelstan que demonstra ser o último grande período da política anglo-saxônica; a possibilidade de um maior desenvolvimento cultural; a imagem real de Athelstan como a imagem de um rei inteligente, curioso, benevolente, enérgico, interessado na obtenção de conhecimento e devoto, qualidades que o distingue dos demais governantes e o une a imagem de Alfred; enfim, como já dissemos anteriormente, são diversos fatores que contribuiriam para o florescimento de uma obra

${ }^{137}$ PAGE, 1997, pp. 119-121. 
como Beowulf, onde está realçada a imagem do rei saxão, do aspecto heróico, que está presente em outras obras, como a Batalha de Brunanburh, assim como por todo o período e que podemos verificar nas passagens da Crônica Anglo-Saxônica que foram registradas em versos. Levando em conta todos esses elementos, podemos estabelecer um gráfico que indicaria este desenvolvimento cultural na Inglaterra (vide Gráfico 2).

Seguindo a idéia levantada, a respeito da composição do poema, Beowulf teria sido então composto no que denominamos como Período Alfrediano. Este Período Alfrediano seria o período que estaria localizado justamente no momento entre o fim do Grande Exército e a coroação de Cnut, o Grande. Definimos assim então este período, diferente de se referir simplesmente ao século X, ele também englobaria o mesmo, pois se estenderia desde em trono de 871 (governo de Alfred, o Grande) até Æthelred II, em 1016. Neste período é que teria se dado a composição de Beowulf; ou seja, quando ele tomou sua versão mais próxima do que temos hoje (vide Figura 1), provavelmente no governo de Athelstan.

A ascensão do Período Alfrediano se dá com os governos de Alfred e seu filho Edward I (os primeiros a ter impedido o avanço viking e promovido uma retomada cultural, com suas traduções latinas, e difusão de livros, a Crônica Anglo-Saxônica e etc; já o segundo por ter seguido os passos do pai, mantendo o que o mesmo fez e reconquistando, ou melhor, submetendo a região centro-sul da Inglaterra que estavam sob domínio escandinavo, principalmente Mercia e Anglia Oriental). O ápice desse período é o governo de Athelstan, pois ele confirma as obras do avô, como também um período de relativa paz (principalmente social), e continua o trabalho do pai ao submeter 


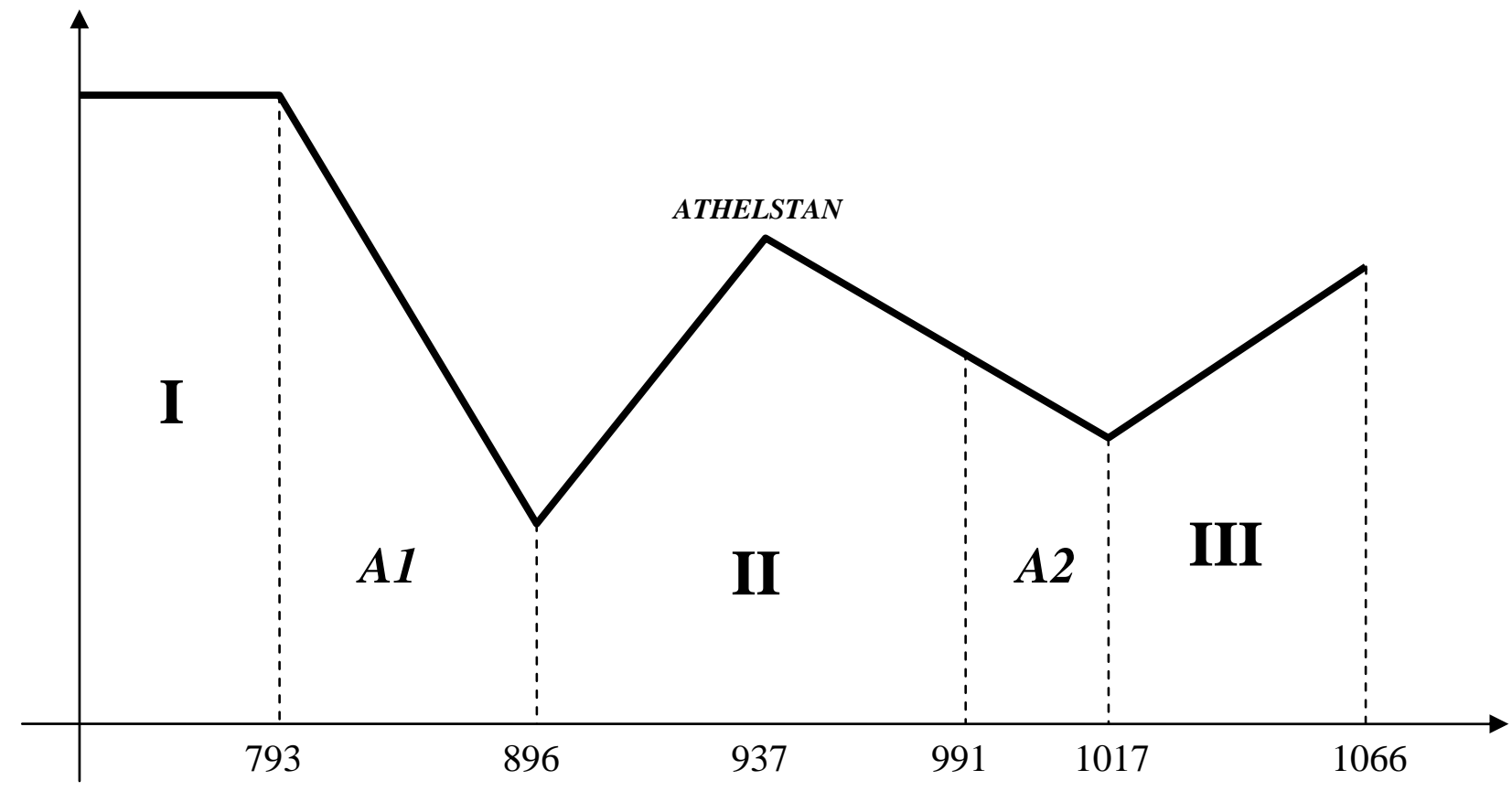

I - Renascença Northumbriana A1 \& A2 - Ataques vikings.

II - Período Alfrediano

III - Período de Cnut

793 - ataque a Lindisfarne.

896 - fim do Grande Exército.

937 - Batalha de Brunnanburh.

991 - Batalha de Maldon.

1017 - coroação de Cnut, o Grande.

1066 - Batalha de Hastings. 
a região da Northumbria e a consolidação de seu governo com a vitória na batalha de Brunanburh em 937, se tornando assim rei não só dos ingleses mas de toda a Inglaterra. A partir de tais fatores podemos dizer que um poema como Beowulf iria ser aceito e compreendido em seus símbolos por seus ouvintes. A importância de seus versos de abertura, que remontam aos ancestrais da Casa de Wessex, linhagem de grandes líderes e guardiões de seu povo (além de fundador da linhagem dos reis dinamarqueses), não passaria despercebida pela platéia de oficiais e aristocratas ingleses e escandinavos; não dentro de um reino da Inglaterra cuja natureza pode ser muito bem representada pelo título de seu rei: Angelsaxonum Denorumque gloriossissimus rex.

Os governos subseqüentes a Athelstan não são muito expressivos (Edwig e Eadred), até Edgar; considerado um governo de paz social, militar, econômica, mas é com ele que se inicia a crise do período devido a reforma religiosa (que afeta diretamente a aristocracia), que refletirá de forma completa no governo de Æthelred II, afetando a sociedade anglo-saxônica, culminando na queda absoluta e total, e da pior forma possível que é sua derrota e da casa de Wessex para os dinamarqueses, e a ascensão ao trono de Cnut, o Grande.

\section{II.3 - Poesia heróica em Wessex}

Como pudemos observar, o período que se inicia com a ascensão de Alfred ao trono de Wessex (chamado por nós como período alfrediano), teria possibilitado um momento de maior estabilidade interna na Inglaterra e um cenário propício para a produção de uma obra como Beowulf.

Vimos qual era o cenário da Inglaterra anglo-saxônica do período das invasões vikings, e depois as especificidades em torno da casa de Wessex e os elementos que supostamente teriam contribuído para o surgimento de Beowulf. Agora iremos nos aprofundar justamente na hipótese levantada anteriormente a respeito de um momento onde teria ocorrido uma maior produção literária. Falando de forma mais específica, vamos agora analisar alguns elementos desta produção literária, e em especial poética, do período do alfrediano. Como veremos, boa parte da documentação poética que conhecemos é datada dentro do período em questão. Desta forma, temos a idéia de que Beowulf talvez tenha sido composto como uma obra que refletia o momento em questão, e não como mera alegoria ou adaptação germânica a um contexto cristão. Como pretendemos observar, é possível que tenhamos um conjunto poético que tenha sido 
construído justamente pelo período alfrediano, como uma forma de criar um novo estilo poético dentro da tradição da Inglaterra.

Um elemento crucial para o entendimento do contexto no qual surgiu boa parte do corpo poético anglo-saxão é justamente o contexto histórico da Inglaterra do século $\mathrm{X}$. Como vimos anteriormente, desde o século VIII a Inglaterra sofreu com os ataques dos escandinavos, até que em meados do século IX três dos principais reinos anglosaxões haviam caído restando apenas Wessex. Assim, é com o rei Alfred, o Grande (871-899), que a resistência contra os viking toma força até que finalmente, ao final do século IX, a Inglaterra acaba sendo dividida em duas partes: o sul nas mãos de Wessex e o centro-norte nas mãos dos escandinavos, a Danelaw. Um elemento de grande importância na resistência de Wessex, em especial para o rei Alfred, era a renovação da vida cristã na população, que sofria os ataques dos pagãos devido ao seu afastamento de Deus $^{138}$. No prefácio de sua tradução para o inglês-antigo da Regula Pastoralis de Gregório, o Grande, Alfred diz: “Lembrem-se dos castigos que caíram sobre nós neste mundo quando nós mesmos não partilhamos o aprendizado nem o transmitimos para outros homens. Nós somos cristão apenas de nome, e muito poucos de nós possuem virtudes cristãs»139. Entretanto, ele mesmo nos releva o caminho para remediar tal situação:

“Me parece melhor (...) que nós também nos voltemos para a linguagem que nós todos possamos entender certos livros que são os mais importantes a qualquer homem conhecer; e assim que realizarmos isso, assim como com o auxilio de Deus nós possamos facilmente ter a disposição paz o suficiente, para que assim todos os jovens nascidos livres agora na Inlgaterra que tenham meios a se dedicar a isso, possam se voltar ao aprendizado (desde que eles não sejam desejados para outros serviços) até o momento em que eles possam ler adequadamente escritos em inglês...”.

Alfred realizou uma reforma cultural e religiosa, reunindo em sua corte mentes de toda a Inglaterra e além, e assim traduziu para o inglês-antigo diversas obras que de certa forma eram de relevância para a crise existente no século IX. Entre as obras traduzidas, além da Regula Pastoralis, estavam Consolatio Philosophiae de Boethius, Historia Ecclesiastica Gentis Anglorum de Beda e Historiae Adversum Paganos de Orosius $^{140}$. A Regula Pastoralis forneceu aos bispos as instruções necessárias para levar

\footnotetext{
${ }^{138}$ KEYNES \& LAPIDGE, 1983, p. 125.

${ }^{139}$ KEYNES \& LAPIDGE, 1983, p. 125.

${ }^{140}$ KEYNES \& LAPIDGE, 1983, p. 28-35.
} 
adiante suas obrigações e as bênçãos de Deus. De acordo com a Consolatio Philosophiae, a busca da sabedoria é a obrigação de todo àquele que busca o Senhor. A Historia Ecclesiastica Gentis Anglorum era um lembrete aos ingleses de sua herança cristã, enquanto Historiae Adversum Paganos possibilitava certo conforto aos cristãos atacados pelos pagãos escandinavos da mesma forma como sofridos em Roma pelos visigodos. Alfred encontrou sua própria inspiração nos 50 primeiros Salmos, os quais também traduziu, a respeito das lamentações de outro rei-guerreiro enfrentando

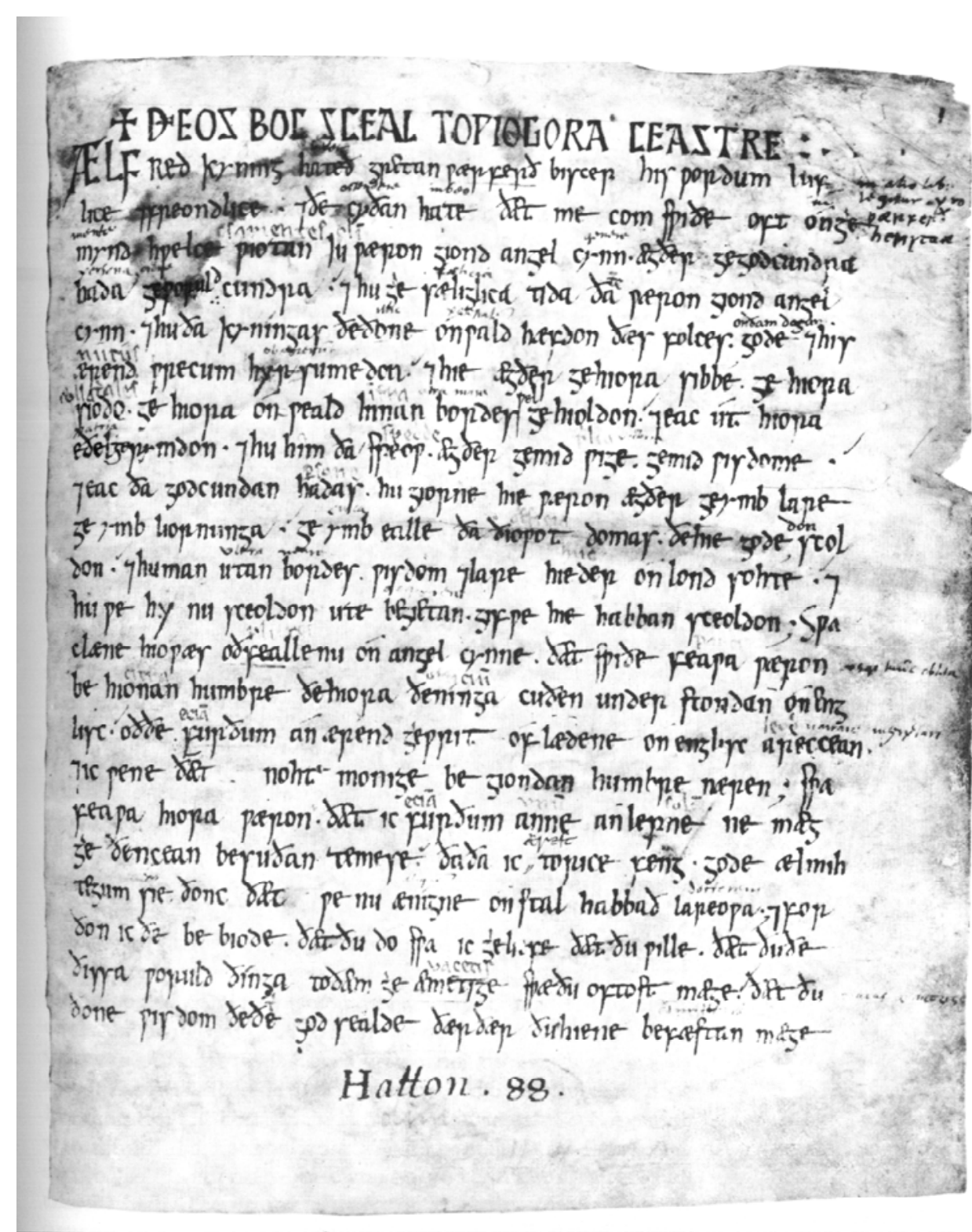

figura 6: Primeira página da Regula Pastoralis feita por Alfred. A inscrição no topo da página diz: "Đeos boc sceal to Wiogora Ceastre” (este livro deve ir para Worcester); e a primeira linha é: “Ælfred kyning hateð gretan Waerferð biscep his wordum luflice”(Rei Alfred envia saudações para o bispo Waerferth em queridas palavras). [James Campbell. The Anglo-Saxons, Londres: Penguin, 1991, p. 158]. 
adversidades frente a um inimigo estrangeiro, o qual é derrotado com o auxílio divino $^{141}$. Entretanto, traduções consistiam em apenas uma parte dos projetos de Alfred. Outros trabalhos incluíam obras originais tanto em latim quanto em inglês-antigo como, por exemplo, A Vida do Rei Alfred de Asser e a Crônica Anglo-Saxônica, quando teve inicio sua organização como tal.

Com os sucessores de Alfred no século X, Wessex gradualmente submeteu as regiões ocupadas pelos escandinavos e consolidou o poder sobre a Inglaterra como um único reino unido. O papel da Igreja anglo-saxônica do século $\mathrm{X}$ foi importante ao cooperar com a Casa de Wessex durante esse período de ascensão da linhagem de Alfred $^{142}$. Também dentro desse contexto, a lealdade e a imagem pessoal do senhor (thegn) foram os pilares sobre os quais se deu a organização militar da Inglaterra anglosaxônica ${ }^{143}$. Enquanto a dependência pela concessão de terras fornecia os meios materiais para os guerreiros cumprirem com suas obrigações militares, o ideal que mantinha o exército unido (o fyrd), e que impunha suas obrigações entre o bandoguerreiro e seu senhor era ainda muito semelhante ao antigo comitatus germânico.

A partir de Alfred, e no decorrer do período alfrediano, surge a iniciativa de reforçar a figura de liderança dos thanes, assim como a reforma do caráter cristão da população. Para essa tarefa, foi possível demonstrar que estes dois objetivos não eram incompatíveis, muito pelo contrário. Para seu mais importante público, formado por uma aristocracia guerreira que era o coração do exército, e acostumado a ouvir os poemas e canções dos antigos heróis da tradição germânica, a utilização da poesia para atingir estes dois objetivos era ideal. Assim, um novo corpo poético surge, baseado na tradição das canções dos scops (poetas anglo-saxões) e na tradição das Sagradas Escrituras e elementos cristãos.

Esta pratica pela união de aspectos tipicamente da tradição germânica com elementos cristãos não era de todo original. Já na Northumbria do século VII podemos encontrar este tipo incorporação de elementos do idioma germânico, aplicados a um contexto religioso cristão. Isto ocorre com um dos mais antigos textos conhecidos do período que é o Hino de Cadmon, onde encontramos o termo dryhten (senhor), que em seu sentido original designa justamente o líder, o comandante de tropas, o senhor do fyrd; mas, dentro do corpo poético do período, é uma das palavras mais comuns

\footnotetext{
${ }^{141}$ KEYNES \& LAPIDGE, 1983, pp. 31-32, 153, 301-303.

142 JOHN, 1991, pp. 160-91.

143 ABELS, p. 186.
} 
referentes a Deus e Cristo. Apesar de Beda afirmar que Cædmon teria composto outros poemas a respeito de muitos outros temas cristãos (tanto do Velho Testamento quanto dos Evangelhos) ${ }^{144}$, o Hino de Credmon é tudo o que chegou até nós. Outros exemplos onde podemos encontrar caso semelhante como de Cædmon é, mas já de um período posterior (em torno do ano mil), nos poemas do Codex Junius XI: Gênesis, Exodus, Daniel e Cristo \& Satã. O relato de Beda é um importante testemunho de que em meados do século VIII teriam existido outras obras de cunho cristão dentro de um contexto germânico, mas o fato é de que não possuímos nenhuma dessas obras, nos restando apenas conjecturas.

Obras como as que acabamos de citar, devem ter tido grande influência como podemos supor. Entretanto, uma dessas obras mais importantes não está na Inglaterra, mas sim no continente. A mais completa adaptação dos Evangelhos a um universo heróico com Cristo como líder de um bando-guerreiro de apóstolos é de meados do século IX. É o poema Heliand, escrito em saxão-antigo e com aproximadamente 6000 versos. O poema pode ou não ter sua inspiração devido a influência dos missionários ingleses no continente ${ }^{145}$, mas é fato que a obra era conhecida na Inglaterra do século X; a melhor das duas cópias do manuscrito de Heliand que existem (a outra seria cópia de Munique) foi copiada em Winchester na segunda metade do século $X^{146}$. Diversos outros poemas em inglês-antigo apresentam essa imagem heróica de Cristo como o comandante de anjos e homens. Nos poemas Cristo I, II e III, Deus é chamado, entre outros epítetos, como:

“sigores frea” (“Senhor da Vitória”, Cristo I, v. 404), “wigendra hleo ... / helm alwihta" ("Defensor dos guerreiros.../ Guardião de todos os seres”, Cristo I, vv. 409410), “apeling ... / beorn” (“príncipe ... / herói”, Cristo II vv. 448-449). Ele também é aquele que lidera o seu “pegna gedryht” (“bando de thanes”, Cristo II, vv. 457).

Cristo, claro, é o maior exemplo para os cristãos, mas outras figuras acabaram por oferecer exemplos tão heróicos quanto. Além do exemplo do comportamento de Satã no poema Gênesis $B$, que como um thane traidor desafia seu lorde Criador, tentando Adão e Eva para longe do caminho do Senhor; os anglo-saxões se valiam das imagens de Abraão, Moisés e até mesmo Judite como líderes enviados por Deus para o Seu povo. Guthlac, Elena, André e Juliana são poemas hagiográficos onde seus santos

\footnotetext{
${ }^{144}$ BEDA, Historia Ecclesiastica Gentis Anglorum, IV, 24.

${ }^{145}$ WORMALD, Patrick. "Anglo Saxon Society and its Literature” in: GODDEN, 1994, pp. 8-9; BOSTOCK, pp.177-83.

${ }^{146}$ MURPHY, 1995, pp.26-27.
} 
são como heróis em acirrado combate contra as forças malignas. Podemos colocar esses poemas hagiográficos, juntamente com Êxodo e Judite, na mesma tradição do poeta latino Prudêncio com sua Psychomachia, devido a sua alegoria ao conceber a existência da alma como uma guerra das virtudes contra os vícios. Justamente esta alegoria do combate unida com as imagens heróicas de santos e de Cristo contra os inimigos do Senhor, era a imagem que seria desejada por Alfred e por Wessex no período em que viviam ao confrontarem os pagãos escandinavos.

Um outro exemplo de como esta poesia de cunho heróico pode estar ligada a resistência e reconquista de Wessex contra os escandinavos, pode ser vista no poema que citamos anteriormente Judite. Claramente em Judite, temos uma alteração da história bíblica e a inclusão de elementos que se encaixariam perfeitamente na sociedade anglo-saxônica do século X. Em sua oração, a heroína clama pelo auxilio divino e diz:

“Deus do início, Espírito do conforto, Filho do Governante universal” (Judite, vv. 83-84), e mais tarde pede para que: "com essa espada possa destruir esse que concede a morte violenta” (Judite, vv. 88-90), e ao final do poema ela recebe sua recompensa:

“Como prêmio, o celebrado guerreiro trouxe de volta para ela da expedição a espada e o sangrento elmo de Holofernes assim como sua grande cota-de-malha adornada de ouro vermelho; e tudo que o implacável senhor dos guerreiros possuía de riquezas ou bens pessoais, de anéis e de belos tesouros, eles deram para aquela linda senhora.” (Judite, vv. 334-341).

Entretanto, a Biblia diz apenas que: "Deram a Judite a tenda de Holofernes, toda a sua prataria, os leitos, as vasilhas e todos os seus móveis” (Jt 15, 11).

Uma possibilidade que podemos levantar seria, nesse caso específico, de um possível paralelo entre a figura de Judite do poema em inglês-antigo e a rainha Æthelflæd de Mercia, a “Senhora dos mercios”. Não podemos afirmar com certeza se realmente há tal ligação, mas de qualquer maneira é uma idéia bem atraente, tendo em vista o período no qual surge o poema e a própria imagem de Æthelflæd, que era filha de Alfred, o Grande, irmã de Edward, o Velho e esposa de Ealdorman Æthelred de Mercia durante o período de reconquista e consolidação do poder sobre os territórios ocupados pelos escandinavos; sendo sua pessoa de grande peso para a liderança de Mercia contra os pagãos. 
Outros dois poemas importantes, frutos deste período alfrediano, podem ser encontrados na Crônica Anglo-Saxônica. O primeiro refere-se ao ano de 937, a conhecida Batalha de Brunanburh, a qual citamos anteriormente neste capítulo, e a outra se refere ao ano de 991, a Batalha de Maldon. Em ambas iremos encontrar este caráter heróico que vimos nos poemas hagiográficos, além de se encaixarem na idéia de uma produção literária promovida a partir do ideal do rei Alfred. A Batalha de Brunanburh pode ser comparada com o poema, composto em alto alemão-antigo, Ludwigslied, que celebra em termos cristãos semelhantes ao estilo dos poemas anglosaxões, a vitória em 881 dos francos do rei Luís III sobre os vikings em Saucourt. Os fatos históricos são tratados inteiramente devido a intervenção divina, desde a chegada dos pagãos como punição sobre os francos devido a seus pecados, ao chamado de Luis por Cristo para a batalha para auxiliar o povo arrependido, até a vitória dos francos pela a inspiração divina manifesta através do rei. O que podemos observar tanto na Ludwigslied quanto na Batalha de Brunanburh é a similaridade no que diz respeito a valores alicerçados na figura do rei, cristianismo e território ${ }^{147}$. Além disso, segundo John Hill, a Batalha de Brunanburh faria parte de uma série de referências dos séculos IX e X na Crônica Anglo-Saxônica como parte de uma construção de uma nova “mitologia” da realeza cristã a serviço da Casa de Wessex ${ }^{148}$. A partir disso, podemos falar de um projeto muito maior que envolveria não apenas a Crônica Anglo-Saxônica, mas também todo o corpo poético anglo-saxão em prol de Alfred, o Grande e seus herdeiros e descendentes.

Além de Brunanburh, outro importante poema na Crônica Anglo-Saxônica é a Batalha de Maldon, um fragmento composto de 325 versos com seu início e fim perdidos. Maldon, diferente de Brunanburh, não comemora uma grande vitória, mas sim uma avassaladora derrota dos anglo-saxões em 991; entretanto, nele iremos encontrar diversas imagens deste heroísmo cristão-germânico que marca todo o corpo poético do período alfrediano. Iremos analisá-lo de forma mais aprofundada no próximo capítulo, mas é interessante observarmos na Batalha de Maldon, como se desenvolvem as personagens, pois elas refletem justamente a aristocracia anglosaxônica com seus exemplos modelares e virtudes: a lealdade dos thanes para com seu senhor, o destemor frente ao combate e a morte. Elementos estes que estão presentes também num dos maiores poemas desta tradição: Beowulf.

\footnotetext{
${ }^{147}$ WOLF, 1991, p. 81.

${ }^{148}$ HILL, 2000, pp. 93-107.
} 
Seguindo nossa hipótese de uma construção ideológica através de um corpo poético; podemos ver Beowulf dentro de um propósito que Alfred e seus sucessores teriam elaborado para a construção de um modelo heróico cristão como exemplo para a expansão de Wessex. O poema traz todos os sinais desta figura heróica cristãgermânica: Beowulf é o herói enviado por Deus que luta com auxilio divino e a seu serviço. Ele é enviado por Deus para ajudar o rei Hrothgar e os dinamarqueses (vv. 665668); enfrenta Grendel, que é o inimigo do Senhor, a ira de Deus (“Godes yrre bær” vv. 711), o adversário (“Godes andsacan” vv. 786) e o que enfrentou Deus (“fag wið God” vv. 811); a força de Beowulf vem de Deus (vv. 1270-1273); ele acredita nessa força e em Deus contra Grendel (vv. 669-670) e contra a mãe do monstro (vv. 1550-1556); e ao final de sua vida o herói obtém a glória e a sua salvação (vv. 2819-2820).

Os exemplos citados são apenas alguns entre muitos outros que demonstram que Beowulf não é uma mera adaptação ao cristianismo de uma tradição pré-cristã, mas sim uma obra muito mais complexa que uma simples alegoria. Tal obra pode ser considerada como o reflexo de um impulso de um ideal modelar elaborado pelos tempos de Alfred e da Casa de Wessex no século X; o qual não se limita a Beowulf, mas também pode ser encontrado por todo o conjunto poético do período ${ }^{149}$. A distinção entre o heróico germânico e cristão perde sua importância para nos chamar a atenção muito mais para a forma como se dá sua conciliação, tendo como público alvo uma aristocracia que era o centro do poder anglo-saxão, mas ainda assim submetida ao poder régio, mas que por sua vez também está submetido ao poder do Rei Celestial, o Senhor Eterno (Ece Dryhten). Com o rei Alfred, o Grande se inicia a elaboração de um ideal aristocrático e fundamentalmente heróico cristão, que é uma parte importante dentro da sociedade anglo-saxônica, sendo representada principalmente através das figuras dos reis e de seus guerreiros.

\footnotetext{
${ }^{149}$ Um exemplo que podemos ter é da tradução do próprio rei Alfred da obra de Orosius, referente a figura do rei Leônidas. Nesta passagem, Alfred faz com que Leônidas acredite em Deus para proteger seus homens e a si mesmo contra as ameaças que viriam (ao mesmo estilo que Beowulf em seu combate contra Grendel). MURRAY, 1997, p. 106.
} 


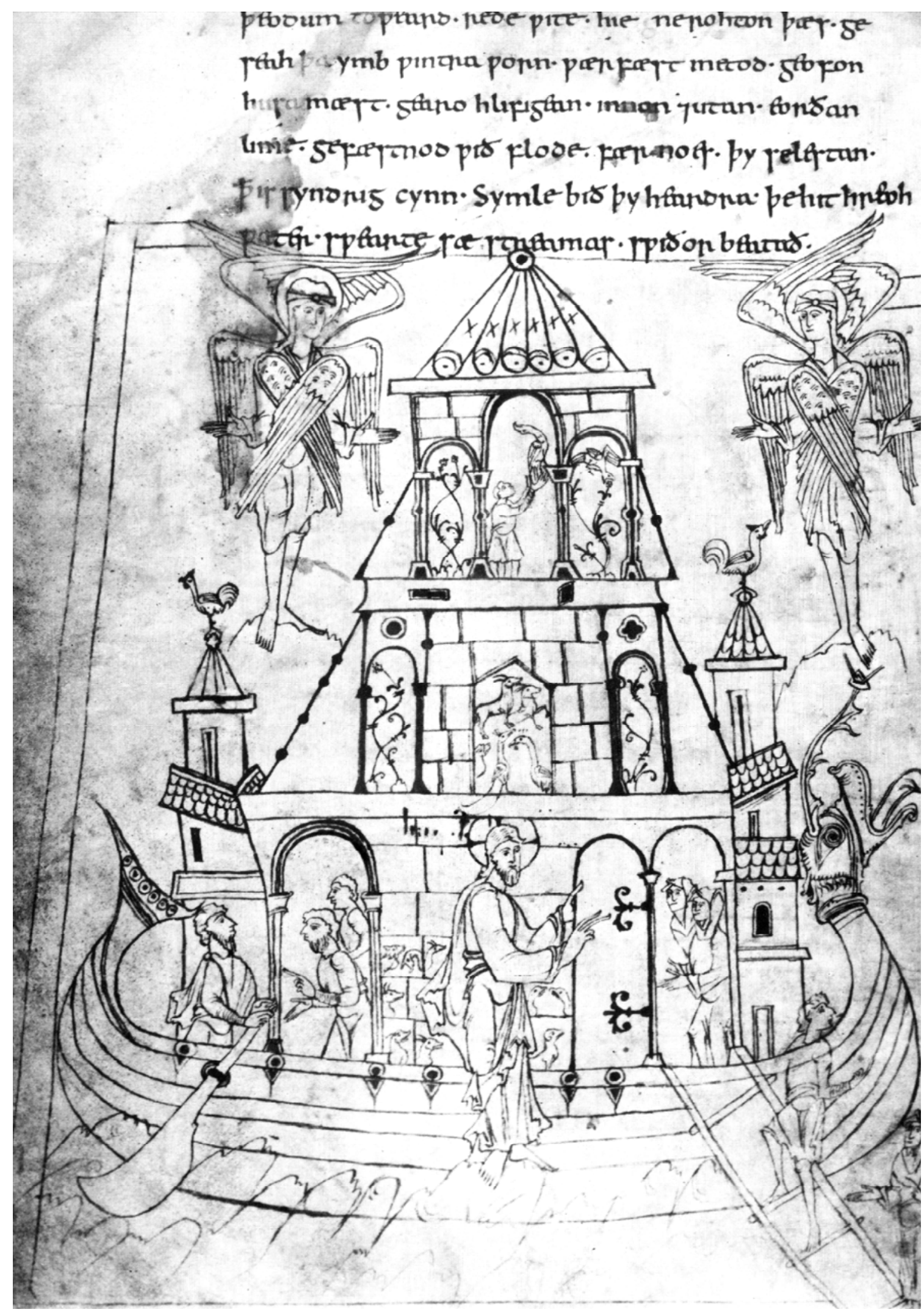

figura 7: Ilustração do poema Gênesis (Codex Junius II, fol. 66r), mostrando Deus fechando a porta da arca de Noé que é representada ao estilo das embarcações anglo-saxônicas e escandinavas. [James Campbell. The Anglo-Saxons, Londres: Penguin, 1991, p. 213]. 


\section{CAPÍTULO III - O Rei, o Guerreiro e o Herói}

"O que torna heróico? - Ir ao encontro, simultaneamente, da sua dor suprema e da sua esperança suprema”. Friedrich Nietzsche, Gaia Ciência.

\section{III.1 - A aristocracia guerreira}

Há muito tempo, como já dissemos, especialistas fazem conjecturas a respeito do poema Beowulf. Ele já foi analisado das mais diversas maneiras e áreas (literatos, folcloristas e etc). Entretanto, no campo do conhecimento histórico, podemos utilizar as palavras de J. R. R. Tolkien:

"So regarded Beowulf is, of course, an historical document of the first order for the study of the mood and thought of the period and one perhaps too little used for the purposed by professed historians" 150 .

Levando em consideração as palavras de Tolkien, vamos agora analisar uma imagem importante e, por que não dizer, um dos elementos principais do poema que é a figura da aristocracia germânica e, diretamente ligada a ela, do rei. Em outras palavras, de que forma a imagem da realeza e dessa aristocracia se apresenta dentro do contexto germânico apresentado através do poema.

Primeiramente, apesar de o antigo debate entre elementos pagãos e cristãos do poema não tenha mais tanta força, ele não deve ser de todo deixado de lado. Como vimos no capítulo anterior, o período alfrediano proporciona uma ascensão de um estilo poético heróico (ao estilo das narrativas germânicas) combinado a um forte caráter cristão. Este amálgama de tradições já é registrado por Beda ${ }^{151}$ ao relatar a carta enviada aos missionários na Inglaterra, no ano de 601, pelo Papa Gregório, o Grande. Nesta carta é dito para que os missionários se apropriassem dos locais sagrados dos pagãos e de suas práticas e as utilizassem em prol da prática cristã. Ou seja, com a conversão as populações pagãs deveriam passar naturalmente para a nova fé ${ }^{152}$. Mas não apenas locais e práticas seriam adaptadas à nova doutrina, mas também (e é um dos elementos

\footnotetext{
${ }^{150}$ TOLKIEN, 1997, p. 20: "Assim considerado Beowulf é, claramente, um documento histórico de primeira importância para os estudos do espírito e pensamento do período e talvez um muito pouco utilizado para este propósito por ditos historiadores”.

${ }^{151}$ Historia Ecclesiastica Gentis Anglorum, I. 30.

${ }^{152}$ FLETCHER, 1999, pp. 253-255.
} 
de grande importância) a terminologia utilizada pelas populações convertidas ou alvo para a mesma ${ }^{153}$. Pensando no caso de Beowulf e de todo conjunto poético do período, um elemento facilitador para um maior contato com a tradição dos pagãos foi justamente o fato da utilização do idioma vernáculo. O exemplo disto que estamos falando é a utilização de palavras e termos desta sociedade germânica, mas agora com sua aplicação ao âmbito cristão ${ }^{154}$. Isto nos remete novamente ao artigo de Tolkien,

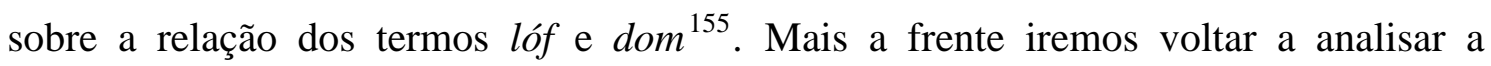
importância desses termos adaptados ao contexto religioso cristão.

Existem outros sinais dessa união entre a tradição germânica e a cristã. Por exemplo, a importância da figura régia dentro desta sociedade, que entre outras coisas possui a chamada mana, ou seja, o "poder" que acabará se tornando a "graça” cristã ${ }^{156}$. Teremos também nesse período uma fusão das imagens do templo pagão, do salão real e do templo cristão. Essas três figuras se mesclam; sendo assim, as primeiras igrejas anglo-saxãs tinham um aspecto semelhante aos salões reais. E com razão seria possível tal referência uma vez que dentro dessa construção de idéias, Deus é o "monarca celeste”, e nada mais natural que seu templo-morada fosse um salão real ${ }^{157}$. Existe ainda uma certa comparação do salão do rei Hrothgar, o grande Heorot, a um tabernáculo ${ }^{158}$. É interessante observarmos que na Inglaterra teria ocorrido um fenômeno singular durante a cristianização. Não existem grandes conflitos entre cristão e pagãos, muito pelo contrário.Um exemplo vivo de como se deu essa união de elementos cristãos dentro de um mundo germânico foi o rei Oswald da Northumbria; oriundo de uma linhagem de reis pagãos, mas ele mesmo converso. Entretanto, mesmo cristão, mantinha certas praticas pagãs, como a postura em que se colocava em suas orações (sentado com as mãos sobre os joelhos e as palmas para cima) o que remeteria a uma prática de cultos

\footnotetext{
${ }^{153}$ Com a conversão vamos encontrar termos que antes eram empregados para significar "sacrifício" (husl, huslian), mas agora empregados num contexto cristão. Ainda também ocorre a entrega de oferendas nas missas, o que manteve a familiaridade para os conversos com os antigos cultos de seus ancestrais (CHANEY, pp. 69-70). Outro elemento, que também já observamos, e que é fundamental para as sociedades germânicas, é a importância de suas linhagens de seus ancestrais. O fato das linhagens dos reis anglo-saxões remontarem até os antigos deuses germânicos e posteriormente as linhagens bíblicas demonstra bem este sincretismo. Um bom exemplo no continente se deu com o líder frísio Radbod. Segundo o relato, Radbod estaria já prestes a ser batizado quando recusou, dizendo que preferia ir para o Inferno e se juntar a seus antepassados, do que chegar ao Céu sem eles (FLETCHER, 1999, p. 239). Ainda com relação à importância dos ancestrais, há uma referência de William de Malmesbury a respeito de uma suposta origem de Scef (como sabemos, figura presente na ancestralidade da linhagem de Wessex e em Beowulf) na arca de Noé. Mais um sinal de união das duas tradições. Ver CHANEY, p. 41.

${ }^{154}$ Termos este que pudemos observar no capítulo anterior.

${ }^{155}$ Abordados no capitulo I.

${ }^{156}$ CHANEY, pp. 55-56.

${ }^{157}$ CHANEY, pp. 76-77.

${ }^{158}$ TOLKIEN, 1997, p. 27.
} 
pagãos $^{159}$. Como podemos ver, a conversão ao cristianismo, ao menos na Inglaterra, não se deu por simples comparações e similaridades entre as duas tradições, mas sim por uma aceitação e integração ao contexto sócio-político do universo germânico anglosaxão. Entretanto, para que isso viesse a ocorrer, devemos atentar para a importância da imagem do rei dentro deste contexto de conversão. Segundo a tradição pagã germânica, os deuses (e mais tarde Deus) são, antes de qualquer coisa, os deuses do rei, que é responsável pelo bem estar de seu grupo. Isto acabava sendo refletido em situações onde reis conversos mantinham governos cristãos, mas bastava que o rei se afastasse do cristianismo para que o paganismo voltasse com força ${ }^{160}$. Ou seja, o ponto central não era apenas a conversão da população, mas sim daquele que era o vínculo entre o terreno e o sagrado: o rei; e, por conseguinte, sua tribo também acabaria por se alinhar à fé de seu senhor. Assim, segundo consta nos códigos do rei Æthelred $\mathrm{II}^{161}$, um rei cristão é o escolhido, o representante de Cristo na terra (Cristes gespelian) entre os cristãos:

"As the heathen king, the representative of gods among the folk, was responsible for the tribe's right relationship with the divine, so his Christian successor continues the same function in later terms” ${ }^{162}$.

Como podemos ver, dentro desse período de conversões, a figura do rei é de suma importância para que a nova fé viesse a se estabelecer na Inglaterra. Extremamente ligada à figura do rei vamos ter também a aristocracia que apesar de não possuir o mesmo papel sagrado de mediadora entre os mundos do sagrado e do profano, ainda assim goza de certas similaridades como a legitimação de sua autoridade por sua linhagem e certas qualidades que a assim a diferencia de outros grupos dentro da sociedade. São justamente essas características que iremos encontrar dentro de Beowulf, onde poderemos observar o ideal social construído com base nessa mescla de elementos de uma tradição cultural germânica e cristã. Através delas fica claro o ideal aristocrático e heróico que pode ter surgido dentro do período alfrediano, como o reflexo da hegemonia da casa de Wessex.

\footnotetext{
${ }^{159}$ CHANEY, pp. 116-117.

${ }^{160}$ CHANEY, pp. 156-161.

${ }^{161}$ Sendo mais específico, seria no códice VIII Æthelred.

${ }^{162}$ CHANEY, pp. 65-67, 185-186: “Assim como o rei pagão, o representante dos deuses entre o povo, era responsável pelo bom relacionamento da tribo com o divino, assim seu sucessor cristão continua com a mesma função de forma posterior". Podemos observar também que o rito de coroação realizado três vezes ao ano (seguindo o calendário pagão, e mais tarde o cristão) representava a confirmação da sacralidade do poder real; o elo do rei entre o povo e a divindade.
} 

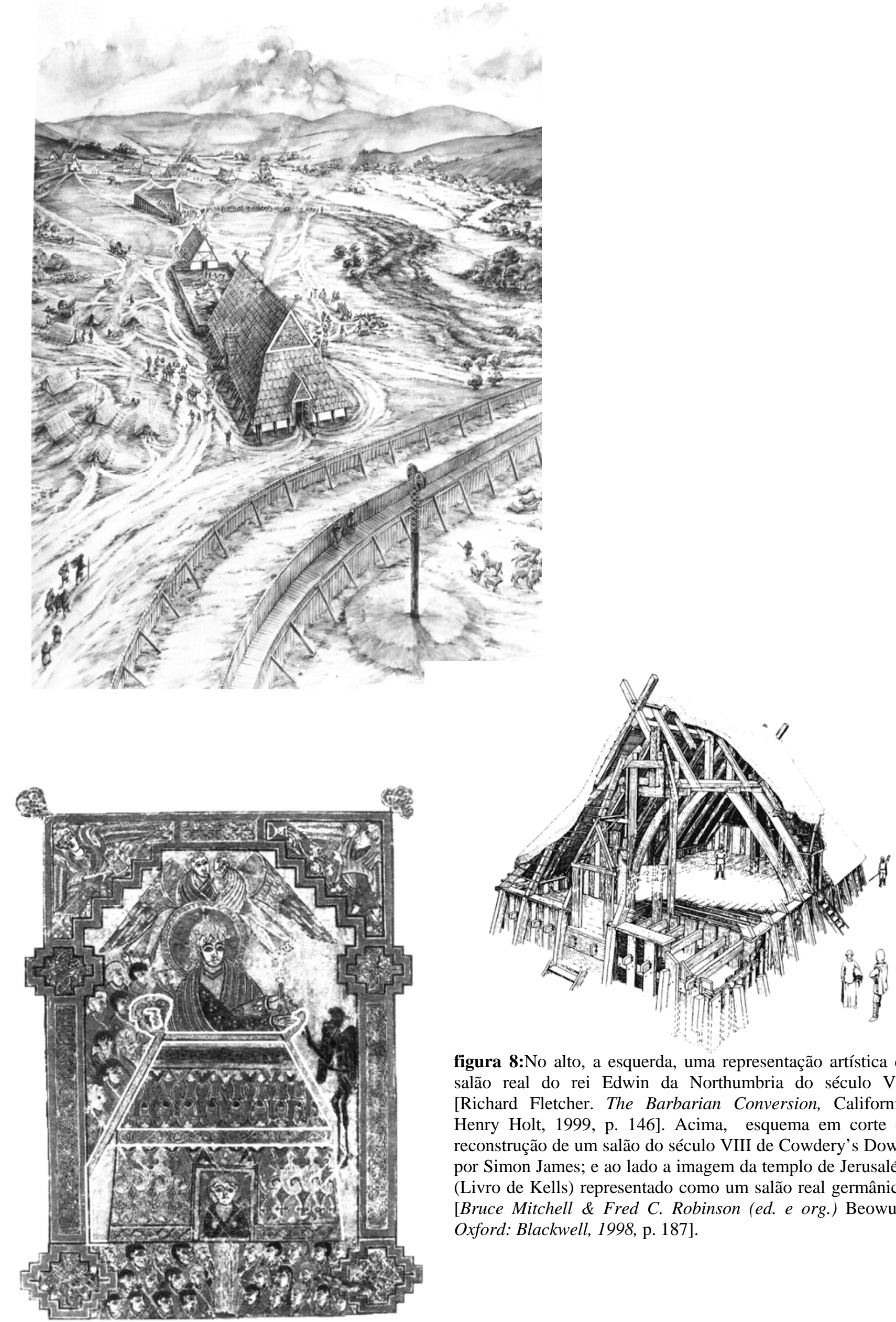

figura 8:No alto, a esquerda, uma representação artística do salão real do rei Edwin da Northumbria do século VII. [Richard Fletcher. The Barbarian Conversion, California: Henry Holt, 1999, p. 146]. Acima, esquema em corte da reconstrução de um salão do século VIII de Cowdery’s Down, por Simon James; e ao lado a imagem da templo de Jerusalém (Livro de Kells) representado como um salão real germânico. [Bruce Mitchell \& Fred C. Robinson (ed. e org.) Beowulf, Oxford: Blackwell, 1998, p. 187]. 


\section{III.2 - As qualidades aristocráticas}

Primeiramente, devemos nos perguntar, dentro deste cenário que o poema nos apresenta, o que caracterizaria a figura real e aristocrática. Para tal questionamento, podemos nos ater inicialmente aos primeiros versos do poema Beowulf:

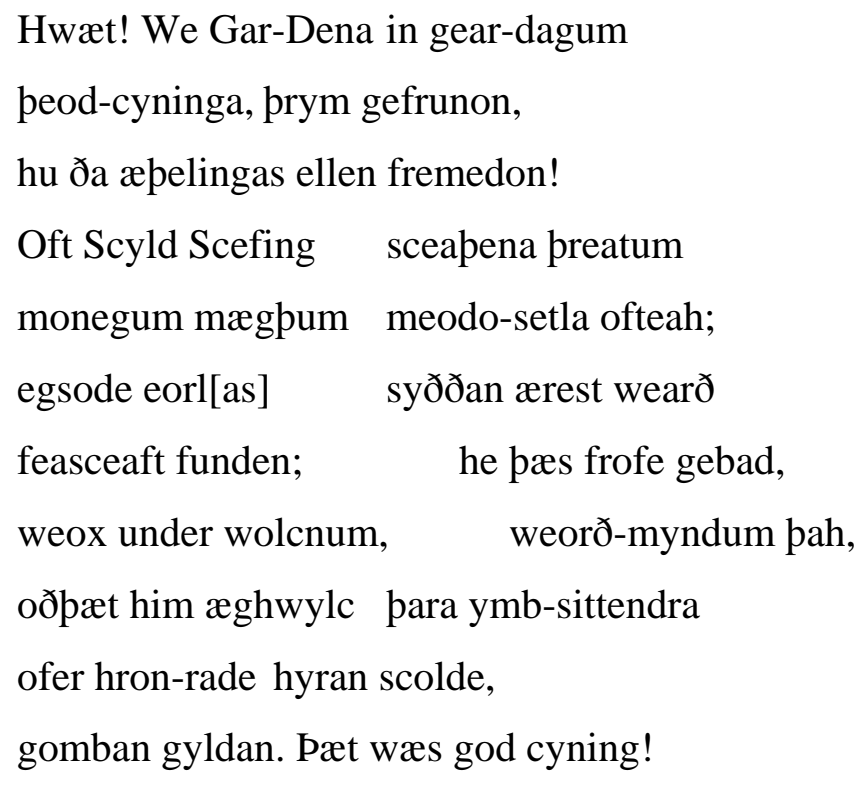

[Ouçam! Nós dos guerreiros dinamarqueses dos dias de outrora,/ dos reis de sua tribo, ouvimos falar de sua glória;/de como esses príncipes realizaram feitos valorosos!/ Por vezes Scyld Scefing de tropas inimigas,/de muitas tribos, tomou os salões;/ele aterrorizou guerreiros, mesmo que a principio fosse/ encontrado sozinho. Mas para isto veio uma solução,/ele prosperou sob os céus, obteve grande honra/ até que cada uma das nações ao longo da costa,/ além do caminho-da-baleia, se submetessem/ e lhe pagassem tributo. Ele foi um bom rei!] (vv. 01-11)

Temos aqui um primeiro contato com a imagem do rei (anglo-saxão ou germânico) apresentado já como um rei aguerrido, um líder militar. Alguém que por seus méritos alcançou seu objetivo, um guerreiro que tomou a liderança de seu povo. Justamente este aspecto mais guerreiro é que estará presente no poema. Mas não pensemos que a caracterização de uma aristocracia se baseie exclusivamente em uma postura de combates. Ao lermos o poema, encontramos diversas passagens de aspecto 
moralizante, de qualidades idealizadas que contribuem para a construção da imagem aristocrática.

Para melhor visualizarmos este universo que Beowulf nos trás, devemos ter em mente, também, outras fontes que se assemelham a ele no que diz respeito justamente à questão da construção da imagem nobre dentro desse contexto norte-europeu. Antes de qualquer coisa, vamos nos ater ao conceito encontrado em Mircea Eliade a respeito das sagas. Segundo esse conceito, a saga (uma narrativa de cunho heróico e, em sua maior parte, de final trágico com a morte do herói) não faria parte de uma tradição puramente popular, mas sim criada e cultivada dentro dos meios aristocráticos com o objetivo de um modelo a ser seguido, um mundo ideal ${ }^{163}$. Este tipo de argumentação pode ser observado durante a ocasião de um fórum a respeito das escavações do sítio arqueológico de Sutton Hoo; durante o fórum, foi levantada a pergunta se "Sutton Hoo seria a realidade por trás do mundo de Beowulf?” e cuja resposta não poderia ser melhor:

“Nem Sutton Hoo nem Beowulf representam uma avaliação precisa da realidade. Ambos contém alusões ao mundo real, mas nós não temos certeza quais elas seriam. A partir do estudo dos sepultamentos nos arriscamos a conhecer muito mais sobre como os anglo-saxões pensavam do que como eles viviam.”164.

Devemos atentar que utilizamos aqui o termo saga como forma de narrativa heróica, como se manifesta no contexto anglo-saxão. Ou seja, uma saga de estilo aristocrático e régio $^{165}$. Outra definição para tais narrativas (já nos aproximando muito mais de seu aspecto literário) seria de que as sagas também poderiam ser definidas como um tipo biográfico de narrativa, com um estilo breve, simples, permeado por versos aliterativos e inicialmente pertencente a uma cultura oral (até que finalmente fossem registradas de forma escrita a partir do século XI e XII); nela abundam genealogias, atritos e combates. Seguindo certa ordem cronológica (ainda que imprecisa e/ou ficcional), não há um aprofundamento das personagens ao decorrer da narrativa, e estes são representados por meio de suas falas e atos; constituindo assim seu caráter dramático que envolve as personagens ${ }^{166}$. Isto nos lembra o estilo dos personagens homéricos (personagens épicos) e também os da narrativa bíblica em relação ao seu papel e função exemplar:

\footnotetext{
${ }^{163}$ ELIADE, p. 171.

${ }^{164}$ CARVER, pp. 173-174.

${ }^{165}$ BUHL, pp. 6-9.

${ }^{166}$ BORGES, 2005, pp. 117-118.
} 
“Os relatos das Sagradas Escrituras não procuram o nosso favor, como os de Homero, não nos lisonjeiam para nos agradar e encantar - o querem é nos dominar, e se nos negamos a isto, então somos rebeldes. Não se queira objetar que isto é ir demasiado longe, que não é o relato, mas a doutrina religiosa que apresenta estas pretensões, pois os relatos justamente não são, como os de Homero, mera 'realidade' narrada. Neles encarnam-se doutrina e promessa indissoluvelmente fundidas; precisamente por isso tem um caráter recôndito e obscuro, contêm um segundo sentido, oculto”. 167

No caso específico do desenvolvimento desta tradição modelar dentro da Inglaterra anglo-saxônica, de forma geral, vemos que conforme tais narrativas se desenvolvem, as circunstâncias e elementos que lhes deram origem são simplificados, distorcidos ou exagerados. Tribos menores e personagens de pouca expressão são suprimidas em favor de elementos mais significativos; a cronologia é reorganizada de forma que personagens e tribos de locais e épocas diferentes passem a coexistir num mesmo momento de um passado mítico, indefinido, no qual o ponto central passa a ser a figura individual do herói biografado e do grupo em que vive. Assim, as narrativas acabam por se desenvolver através das ações destes personagens às necessidades do momento frente ao seu código heróico moral de conduta. Mas uma vez que se trata de uma narrativa “cristianizada”, ela possui tanto os elementos heróicos épicos, próximos de Homero, quanto a função doutrinária bíblica. Desta forma, através de um texto como Beowulf, podemos notar a presença dos dois estilos: vemos os personagens do poema serem caracterizados através de suas falas e atos, sem uma maior profundidade, mas serão justamente essas suas características que acabam por desempenhar a função do modelo exemplar social a ser levado a seu publico alvo ${ }^{168}$.

Uma das formas nas quais essa idealização se manifesta é através da construção de uma aristocracia por meio (como já dissemos) de elementos moralizantes; dentre eles estariam as habilidades e qualidades atribuídas a suas personagens. Este aspecto da importância de tais qualidades é um elemento de grande valor a se levar em consideração. Dentro dessa tradição, existem dois documentos em especial que devem ser citados por sua importância e proximidade com Beowulf. O primeiro documento é Os Dons dos Homens, poema em inglês antigo que narra como Deus distribui as habilidades entre os homens. As habilidades ou qualidades apresentadas nos Dons podem ser encontradas também em outras fontes e sempre se referem a elementos

\footnotetext{
167 AUERBACH, p. 12.

${ }^{168}$ AUERBACH, pp. 14-15.
} 
idealizados por uma aristocracia e presentes nas sagas, onde os personagens em sua maior parte são membros desse mesmo grupo social. Dentre essas habilidades e qualidades podemos ressaltar riquezas, posses (Dons dos Homens, vv. 30-31), sabedoria (vv. 32-33), eloqüência (vv. 35-36), coragem (vv. 39-40), habilidade política (vv. 4143), ser pio e caridoso (vv. 45-46).

As características apresentadas nos Dons dos Homens, também podem ser encontradas de forma semelhante em outro poema anglo-saxão chamado As Fortunas dos Homens, que segue a mesma linha temática a respeito da sina de cada ser. O segundo documento seria A Batalha de Maldon ${ }^{169}$. Em Maldon, há uma passagem que demonstra bem o comportamento aristocrático idealizado, quando Byrhtwald diz:

Hyge sceal by heardra, heorte by cenre, mod sceal by mare by ure mægen lytlap.

[A mente deve ser mais forte, o coração mais valente, /e a coragem grandiosa quando nossas forças se esvaem.] (A Batalha de Maldon, vv. 312-314)

Em Beowulf, o herói, que também é um guerreiro e acaba por se tornar rei, também demonstra as qualidades que deveriam ser admiradas (segundo o conceito das virtudes cardeais): prudência (prudentia), justiça (justitia), coragem (fortitudo), e temperança (temperantia).

Ao analisarmos Beowulf, podemos perceber que outras muitas dessas qualidades estão presentes. Qualidades como reconhecimento em liderança (Beowulf vv. 20-25), habilidades em combate (vv. 287-289 e 1246-1250), coragem (vv. 572-573), honra e glória (vv. 1384-1389, 1534-1536 e 2890-2891), lealdade (vv.2166-2169) ${ }^{170}$. Mas não

\footnotetext{
${ }^{169}$ A Batalha de Maldon: poema aliterativo anglo-saxão, narra a batalha ocorrida no ano de 991 na região de Maldon (sudeste da Inglaterra). Nesta batalha, Earl (conde) Byrthnoth e seus homens lutaram contra invasores vikings, e acabaram sendo derrotados. Segundo o poema, Byrthnoth caiu em batalha e seus guerreiros, por lealdade, não o abandonaram, lutando até o fim contra os invasores.

${ }^{170} \mathrm{Um}$ dos principais elementos da sociedade da Inglaterra anglo-saxônica (e germânica) é questão da lealdade. Aliás, este é um dos elementos mais encontrados na poesia heróica (a relação do thengs para com seu senhor ou rei; entre Beowulf e o rei Hrothgar e o rei Hygelac, e de Wiglaf para com o rei Beowulf). Temos também no poema Heliand, a lealdade dos apóstolos a Cristo como a do bandoguerreiro a seu líder; e isso também está muito relacionado com a idéia de generosidade (o bom rei também é o “doador-de-presentes”). Ver JONES, 1972, pp. 42-45. Podemos encontrar dentro do contexto histórico militar do período uma figura que representa justamente o perfil do jovem Beowulf, o duguð. Este seria o renomado guerreiro do rei, que por seus serviços prestados, recebe terras e presentes de seu senhor, e acaba por atrair outros jovens guerreiros em busca de glórias (os geoguð). Podemos encontrar essas imagens presentes em Beowulf vv. 64-67, 2144-2172. Ver HILL, 2004, p. 38.
} 
apenas valores positivos permeiam o poema. Há também a imagem do traidor, um dos piores ofensas dentro da sociedade germânica ${ }^{171}$. Podemos ver essas passagens justamente como aspectos moralizantes, que podem ser encontrados em outras fontes como as Eddas e sagas escandinavas (Saga dos Volsungs, Saga do rei Hrólf Kraki, Saga dos Jomsvikings) e demais poemas anglo-saxões como Wanderer, Deor e Widsith. Em todos eles encontraremos similaridades no que diz respeito às qualidades e atitudes modelares de seus personagens.

Tolkien disse ${ }^{172}$ que Beowulf não poderia ser classificado como um épico heróico como a Eneida ou Odisséia, entretanto uma característica semelhante aos textos clássicos ele possuiria: as máximas. As máximas dentro de tais obras possuem justamente a função moralizante ou reflexões a respeito do mundo. Num simples levantamento entre os seus 3182 versos, é possível encontrar em torno de 23 passagens que podem ser classificadas como máximas ${ }^{173}$. Com isso, fica cada vez mais clara a função de uma obra como Beowulf dentro de um cenário como o mundo germânico medieval, ou seja, de função modelar.

Levando em consideração Beowulf e os demais documentos referentes a esse meio aristocrático, pode-se dizer que estaríamos frente a histórias com personagens aristocráticos, direcionadas a um público aristocrático e com elementos aristocráticos (feitos sobre-humanos de heroísmo, reis, guerreiros, salões, antigas linhagens); logo, nada mais natural que possuíssem valores e idealizações desse grupo. Podemos dizer que além de entreter, o poeta também estaria instruindo sua platéia:

"The two essential characteristics of such a society (...) are that it shall be warlike and hierarchical, that is, controlled by a military aristocracy whose highest good

\footnotetext{
${ }^{171}$ A condição do traidor e daqueles de sua linhagem é de que são considerados como parias, pois eles não estão apenas contra a lei terrena do rei ou de seu senhor, mas também de Deus. Podemos, com base nisso, estabelecer esse modelo à figura de Grendel e sua sina de pertencer a linhagem de Caim (aquele que se voltou contra a ordem divina e tornou-se um proscrito, e condenando toda a sua descendência, segundo o poema). O que também se encaixa no episódio de Grendel temer e não se aproximar do trono de Hrothgar (um rei investido com poder sacralizado), símbolo do poder régio e também do poder divino. A idéia contra o traidor é de que não apenas ele, mas todos os que venham dele sofrerão a danação eterna por traírem seu rei (terreno e celeste) nas trevas: exatamente a imagem da figura de Grendel (vv. 86-104, 168-169, 1258-67). Ver CHANEY, pp. 210-213, 218.

${ }^{172}$ TOLKIEN, 1997, p.31.

${ }^{173}$ Beowulf, vv. 20-25, 183-187, 287-289, 455, 572-573, 1002-1008, 1060-1062, 1246-1250, 1384-1389, 1534-1536, 1838-1839, 1925-1962, 2026-2031, 2166-2169, 2291-2293, 2444-2449, 2600-2601, 27062709, 2764-2766, 2858-2859, 2890-2891, 3063-3065, 3174-3177.
} 
is the warrior's code (...) War, valour, service, loyalty, liberality, contempt of death, and love of fame: these are the constants of truly heroic verse."

É claro que estes modelos exaltam qualidades dignas de uma aristocracia idealizada, assim como teremos no século XII um fenômeno semelhante com as gestas de cavalaria e as histórias do ciclo arturiano. Além disso, a identificação deste ideal com um ambiente ou com figuras históricas ou pseudo-históricas reforça ainda mais este aspecto moralizante do poema, o que o diferencia de simples contos populares, inserindo seus ouvintes dentro de um universo mítico familiar ${ }^{175}$. Portanto, passando por Hildebrando e a batalha contra os godos e hunos, os feitos de Sigurd/Siegfried, Valtário, Byrhtnoth e a Batalha de Maldon e Beowulf, todos trazem a imagem idealizada, modelar de um mundo aristocrático para seu público, principalmente na forma de narrativas e poemas heróicos, o que também se destaca como uma das características deste tipo de narrativa modelar germânica: a forma poética (e aliterativa) em lugar da prosa.

O que podemos ver é que as narrativas heróicas são algo de extrema importância para essas sociedades, pois através delas é possível uma identificação de todo o grupo social, justamente por seu aspecto fabuloso, mítico e ao mesmo tempo histórico. Até o século XIX, o termo "mito” designava especificamente tudo aquilo que seria avesso à história: o fabuloso, fantástico, utópico. Mas desde então, essa imagem se transformou, e assim:

“Ao invés de tratar, como seus predecessores, o mito na acepção usual do termo, i.e., como “fábula”, “invenção”, “ficção”, eles o aceitaram tal qual era compreendido pelas sociedades arcaicas, onde o mito designa, ao contrário, uma "historia verdadeira" e, ademais, extremamente preciosa por seu caráter sagrado, exemplar e significativo.”"176

Podemos observar que este tipo de construção, através de uma narrativa heróica, possui grande influência em momentos históricos muito além do período medieval. Ou seja, a preocupação, ou a necessidade, pela construção de uma história (propriamente dita) oficial, que mostre as origens e realce os valores e virtudes de uma ou outra sociedade:

\footnotetext{
${ }^{174}$ JONES, 1972, pp. 49-50: “As duas características essenciais de tal sociedade (...) são que devem ser aguerridas e hierárquicas, ou seja, controladas por uma aristocracia militar cujo maior bem é o código guerreiro (...) Guerra, valor, serviço, lealdade, liberalidade, desdém pela morte, e amor pela fama: estas são as constantes do verdadeiro verso heróico”.

${ }_{175}$ JONES, 1972, pp. 38-41.

${ }^{176}$ ELIADE, pp. 7-8.
} 
“Um povo sem história (...) é como se não existisse ${ }^{177 !}$ !"

Um bom exemplo disso pode ser encontrado, também, na Europa do século XIX, quando passa a haver uma nova valorização das tradições históricas de cada país. Temos na Alemanha o resgate de seu passado germânico, que mais tarde resultaria na idéia do "mito ariano", ou seja, de uma origem "nobre”, "heróica”, "primordial”:

"Esse prestígio da "origem” sobreviveu nas sociedades européias. Quando se empreendia uma inovação, esta era concebida, ou apresentada, como um retorno à origem. A Reforma inaugurou o retorno à Bíblia e ambicionava reviver a experiência da Igreja primitiva, ou mesmo das primeiras comunidades cristãs. A Revolução Francesa tomou como paradigmas os romanos e os espartanos. (...) "Temos nossa origem em Roma!”, repetiam com orgulho os intelectuais romenos dos séculos XVIII e XIX. (...) A intelligentsia húngara encontrava uma justificação para a antiguidade, a nobreza e a missão histórica dos Magiares e na saga heróica de Arpad.”178

${ }^{177}$ ELIADE, p. 156.

${ }^{178}$ ELIADE, p. 157. 

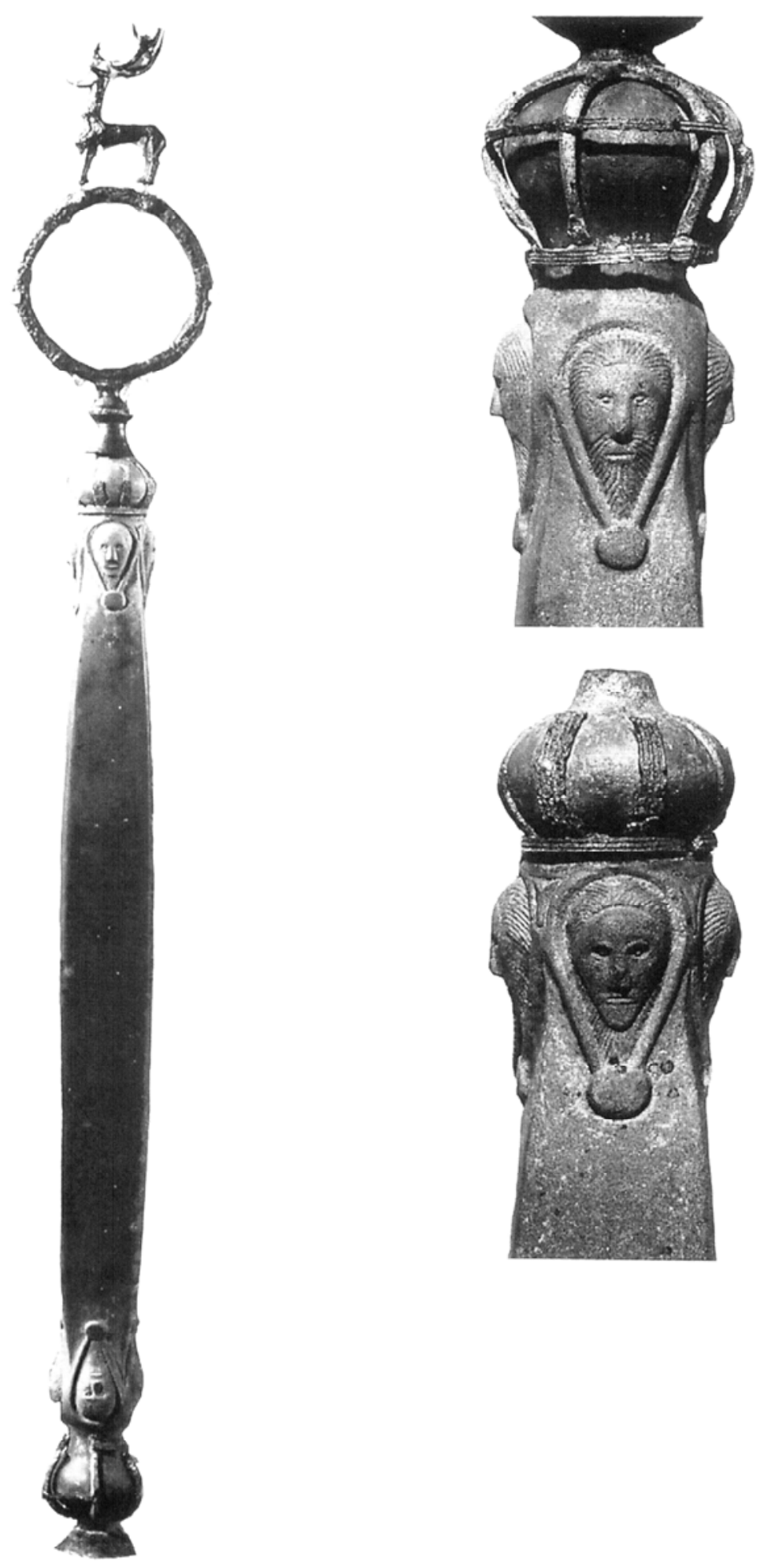

figura 9: O cetro de Sutton Hoo consiste numa peça de pedra de $84 \mathrm{~cm}$. Sua função ainda é obscura. Ele é decorado com a imagem esculpida de quatro faces humanas em cada uma das extremidades, além de uma peça de bronze na forma de um gamo sobre um anel. Entre uma das hipóteses, o cetro seria uma figura mais simbólica do que prática do poder régio. Não há nenhum tipo de peça semelhante de origem germânica ou céltica como este cetro. [Barbara Yorke. Kings and Kingdoms of Early Anglo-Saxon England, Londres: Routledge, 2002, p. 90] 


\section{III.3 - A imagem do rei}

Como vimos, a figura aristocrática germânica presente em Beowulf e demais documentos do período, estaria baseada em todo um conjunto de qualidades e habilidades idealizadas e apreciadas por seus ouvintes. Mas, uma vez que temos uma idéia do mundo aristocrático no qual esses povos germânicos viviam, podemos avançar para um elemento de destaque dessa aristocracia: o rei ${ }^{179}$.

A realeza germânica, em especial a anglo-saxã, surgiu num grande amálgama de elementos cristãos e pagãos. O rei, desde suas origens pré-cristãs, é o mediador entre os poderes divinos e seu povo (folc), e sua imagem está intrinsecamente ligada ao âmbito político e religioso. Ele é a personificação da “sorte” (encontrada ao longo de Beowulf através dos termos eadig e saelig), do destino de seu povo. Uma de suas principais funções relacionadas ao divino é assegurar os favores e bênçãos dos deuses sobre sua tribo servindo justamente como mediador, realizando sacrifícios pela vitória, por boas colheitas e pela paz. O rei não é um sacerdote, mas o líder de seu povo e o guardião de seu bem-estar agindo de forma a receber as graças divinas. As atitudes do mundo político refletem o religioso e vice-versa. De forma clara, podemos identificar a divindade sendo primeiramente a divindade do rei, que tem a função de administrar sua responsabilidade com o mesmo, e de forma secundária como a divindade da tribo; ou seja, a divindade primeiramente não como o "grande pai da humanidade”, mas sim um deus de reis e guerreiros ${ }^{180}$. Através disso, podemos entender certos termos aplicados à imagem régia como o “escudo-do-povo”, o “elmo-do-povo”, ou seja, como o guardião e protetor $^{181}$. Este caráter misto do rei, entre o mundo religioso e o secular, possibilitaria sua influência nas leis e sobre o mundo eclesiástico (lembremos da Eigenkirche). Como nos tempos pagãos, o que temos é o rei como descendente da divindade, com o cristianismo teremos uma identificação do mesmo com Cristo ${ }^{182}$; ou seja, o rei é ao mesmo tempo uma “persona mixta”, que atua através da “sorte”, da "graça" da divindade da tribo:

\footnotetext{
${ }^{179}$ A importância da figura do rei neste mundo germânico anglo-saxão de Beowulf, pode ser observada pela utilização de pelo menos vinte e seis temos para designar a figura real no poema. Ver CHANEY, pp. 7-8.

${ }^{180}$ CHANEY, pp. 34

${ }^{181}$ CHANEY, pp. 11-15.

${ }^{182}$ CHANEY, p. 192.
} 
“O rei, ao contrário de um homem individual, é in officio o tipo e imagem do Ungido no céu, e conseqüentemente, de Deus”"183.

Assim, através deste modelo de identificação da imagem do rei e de Cristo, temos uma permanência, a continuidade de uma tradição que remonta aos tempos pagãos e que se adapta com o a cristianização ${ }^{184}$. Com o tempo, o rei perde um pouco de seu poder ao dividi-lo com a Igreja; entretanto continua como o mediador entre o povo e a divindade. Não há uma forte diferenciação entre pecados e crimes, a autoridade régia acaba tendo influência nas duas esferas ${ }^{185}$. Um exemplo disso pode ser encontrado nas leis de Æthelred II (VIII Æthelred, parágrafo 2.1) ${ }^{186}$.

Um dos principais elementos de sustentação do poder real é referente a sua linhagem, ou melhor, a sacralidade da linhagem real. Alcuíno de York, em carta aos nobres do reino de Kent diz:

"ex antiqua regum prosapia invenitur, et tanto incertioris sunt originis, quanto minoris sunt fortitudinis”

[das antigas linhagens reais existentes, quanto mais incertas suas origens, quão menor será sua força $]^{187}$.

As referências a respeito das linhagens reais anglo-saxãs inicialmente retornariam até antigas divindades germânicas, como vimos anteriormente; e com o passar do tempo, elementos cristãos foram assimilados e as genealogias passaram a terem ancestralidades cristãs, indo além das referências pagãs ${ }^{188}$. Entretanto, a própria figura de Cristo passou também por uma transformação. Poderíamos dizer que ocorre uma "germanização do cristianismo", onde temos uma imagem mais heróica ao estilo germânico onde Cristo e seus apóstolos acabam por se assemelhar a um lorde e seus thegns, ao estilo do comitatus (imagem que pode ser encontrado também no documento Heliand, uma versão dos evangelhos em alto alemão antigo $^{189}$; onde Cristo é retratado justamente dessa forma mais "germanizada”). A imagem de Deus também é uma imagem interessante. Durante o poema, o termo mais comum empregado a Deus é a palavra anglo-saxã God (Deus cristão); mas

\footnotetext{
${ }^{183}$ KANTOROWICZ, pp. 51-52 e 56.

${ }^{184}$ CHANEY, pp. 197.

${ }^{185}$ CHANEY, pp. 234-235.

${ }^{186}$ WHITELOCK, Dorothy. English Historical Documents, Londres, 1955.

${ }^{187}$ CHANEY, p. 17.

${ }^{188}$ CHANEY, pp. 18-20.

${ }^{189}$ Heliand também foi escrito em versos aliterativos, assim como Beowulf, ou seja, ao estilo dos poemas heróicos, aristocráticos.
} 
além dessa denominação, existem outras referências a Ele como: lorde (frea, dryhten), governante ou líder (waldend), líder dos homens (fira waldend), senhor da glória (wuldres waldend), rei da glória (wuldur cyning), líder das vitórias (sigora waldend), rei das vitórias (sigora soðcyning), entre outros ${ }^{190}$. Podemos observar essa imagem germanizada de Deus em dois exemplos da poesia anglo-saxônica (entre outros), nos versos de abertura do Gênesis (onde encontramos uma importante imagem de Deus, sendo citado como “Senhor dos Exércitos”) ${ }^{191}$ e no O Hino de Cæedmon e:

$\mathrm{Nu}$ we sculon herian heofonrices Weard, Meotodes meahte and his modgepanc, weorc Wuldor-Fæder,swa he wundra gehwæs, ece Dryhten, or onstealde.

He ærest scop ielda bearnum heofon to hrofe, halig Scieppend; pa middan-geard manncynnes Weard, ece Dryhten, æfter teode, firum foldan, Frea eallmihtig.

[Agora nós devemos reverenciar o Guardião do reino dos céus, o poder do Criador e a vontade de seus pensamentos, o trabalho do Pai da glória, como Ele, o Senhor eterno, estabeleceu o inicio de toda maravilha. Ele, o Criador sagrado, primeiro criou o céu como um telhado para os filhos dos homens; então o Guardião da

\footnotetext{
${ }^{190}$ CHANEY, pp. 46-52. Apesar da imagem de Deus como rei seja presente por toda a cristandade, entre os anglo-saxões ela se torna majoritária e central. Onde a proximidade da divindade pagã foi aproximada da cristã, promovendo assim uma maior aceitação e menor resistência à nova fé. Por exemplo, a palavra Frea teria sua origem no nome do deus Frey, um dos principais deuses germânicos. Ou ainda, a palavra bealdor (valente), termo muito comum na poesia anglo-saxônica para se referir aos reis e nobres, teria sua origem no nome do deus nórdico Balder (o qual também aparece na genealogia dos reis de Wessex como Baeldaeg).

${ }^{191}$ Esta mesma expressão pode ser encontrada no Velho Testamento em Isaias: "Kadosh, kadosh, kadosh Adonai Tseva'ot" [Santo, santo, santo é o Senhor dos Exércitos] (Is 6,3). É possível termos em Beowulf uma forte influência bíblica (talvez maior do que se imagina), haja visto as passagens sobre a Criação (vv. 86-98) e a linhagem de Caim (vv. 99-114), e a predileção dos anglo-saxões pelas passagens do Velho Testamento. Além disso, dentro do próprio mundo germânico temos a imagem de Woden/Odin como o Alfödr (Pai de Todos), o que pode contribuído para certa similaridade com a imagem do Deus cristão. O que teríamos seria a união da figura divina cristã (do Velho Testamento) com a divindade germânica. Desta forma, o que teremos será uma apropriação do aspecto aristocrático e régio da divindade para o universo cristão, enquanto a divindade em si como entidade é demonizada (como nos versos 175-188 de Beowulf).
} 
humanidade, o Senhor eterno, o Senhor todo-poderoso, mais tarde preparou o mundo, a terra-média] (O Hino de Ccedmon)

Temos também um ótimo exemplo dessa apropriação da figura divina na oração do “Pai-Nosso”, no poema Heliand:

Fadar ûsa | firiho barno,

thu bist an them hôhon | himila rîkea,

geuuîhid sî thîn namo | uuordo gehuuilico.

Cuma thîn | craftag rîki.

Uuerða thîn uuilleo | obar thesa uuerold alla,

sô sama an erðo, | sô thar uppa ist

an them hôhon | himilo rîkea.

Gef ûs dago gehuuilikes râd, | drohtin the gôdo,

thîna hêlaga helpa, | endi alât ûs, he $\underline{b} e n e s$ uuard,

managoro mênsculdio, | al sô uue ôðrum mannum dôan.

Ne lât ûs farlêdean | lêđa uuihti

sô forð an iro uuilleon, | sô uui uuirðige sind,

ac help ûs uuiðar allun | ubilon dâdiun.

[Pai nosso, filhos dos homens, /Tu está no alto reino celeste, /Santo seja Teu nome em cada palavra. /Possa Teu poderoso reino vir. /Possa Tua vontade ser feita sobre todo este mundo, /assim na terra como é lá /nas alturas do alto reino celeste. /Nos dê apoio ${ }^{192}$ a cada dia, bom Lorde, /Teu sagrado auxílio, e nos perdoe, Guardião do Céu, /nossos muitos crimes, assim como nós fazemos a outros seres. /Não permita que pequenas criaturas malignas nos desviem /para fazer suas vontades, como nós merecemos, /mas nos ajude contra todos os atos malignos.] (Heliand, vv. 1600-1612).

\footnotetext{
${ }^{192}$ Do saxão antigo: rad (suporte, apoio, auxílio). O versão original "o pão nosso de cada dia dá-nos hoje" (Mt 6, 11; Lc 11, 3) pode ter sido inaceitável para uma aristocracia guerreira. Por outro lado, eles reverenciariam sem problemas uma figura com um líder guerreiro, seu comandante e senhor, por seu suporte em tempos de guerra e perigo. Esta seria sua principal responsabilidade para com eles em troca de sua lealdade em combate para com ele. Deus, como "Líder de Todos os Homens" é concebido justamente dessa forma proto-feudal de relacionamento: Nós prestamos nossa lealdade a Ele, e em troca Ele nos protege das ameaças do mal. Este quadro se encaixa exatamente na imagem poética anglo-saxônica, como podemos observar.
} 
O que vemos aqui são referências atribuídas a um âmbito político e guerreiro da sociedade, atribuídos à figura divina. O que temos então é a mesma relação atribuída aos guerreiros e lordes para com seu líder e rei, transportadas para um quadro religioso, onde os reis (e seus súditos) é que seriam os thegns de Cristo e de Deus. A partir disso podemos até mesmo estabelecer uma relação que faria sentido dentro desse quadro de conversão do período, onde Cristo teria atuado sob as bênçãos de Deus, sendo assim um mediador entre Ele e os homens; responsável pelo bem de seu povo e para isso se sacrificou e foi levada à cruz. Temos aqui um quadro mítico muito semelhante e com funções iguais aos reis germânicos dentro de sua sociedade. Ou seja, através dessa construção Cristo é rei, membro de uma linhagem sagrada ${ }^{193}$ e filho de Deus, o "monarca celeste”. Desta forma, a imagem de Cristo em relação a Deus, cercado por seus apóstolos é identificada com a do rei germânico. Já em Beowulf as três principais figuras reais são respectivamente: Hrothgar, Hygelac e o próprio Beowulf. Vimos anteriormente as qualidades que constituiriam o ideal aristocrático. Entretanto, o ideal da realeza englobaria os mesmos ideais, e iria além; o ideal de realeza atingiria também o conceito de sapientia et fortitudo ${ }^{194}$.

A relação de sapientia et fortitudo pode ser encontrada nas Eddas, em especial no poema Hávamál (parágrafo 15) ${ }^{195}$, onde diz que:

"O filho de um rei deve ser silencioso e pensativo, e ameaçador em batalha (...)"

Já Isidoro de Sevilha, a respeito do heroísmo nos diz ${ }^{196}$ :

"Heroicum enim carmen dictum, quod eo virorum fortium res et facta narrantur. Nam heroes appellantur viri quase aerii et caelo digni propter sapientia et fortitudinem."

[Chama-se canto heróico porque relata feitos de homens valorosos. Denomina-se, sobretudo heróis os homens dignos do céu por sua sabedoria e valor]

\footnotetext{
${ }^{193}$ Mt 1: 1-17; Lc 3: 23-38

${ }^{194}$ KASKE, 1966, pp. 273-274. A relação de sapientia et fortitudo, como veremos, pode ser encontrada dentro do cristianismo como do paganismo germânico. Ampliando este conceito, poderíamos também estabelecer paralelos com as imagens de Deus e Wyrd (destino), que por vezes podemos identificar no poema Beowulf, assim como sua ligação direta com glória e honra (lof e dom).

${ }^{195}$ HOLLANDER, p. 17

${ }^{196}$ CURTIUS, pp. 232-233.
} 
Este mesmo conceito pode ser encontrado na poesia anglo-saxã como nos Dons dos Homens (vv. 39-43, 76-77) e no final de Widsith:

$$
\begin{aligned}
& \text { simle suð oppe norð summe gemetað } \\
& \text { gydda gleawne geofum unhneawne } \\
& \text { se pe fore dugube wile dom aræran, } \\
& \text { eorlcipe æfnan oppæt eal scæceð } \\
& \text { leoht ond lif somod; lof se gewyrceð, } \\
& \text { hafað under heofonum heahfæstne dom. }
\end{aligned}
$$

[sul ou norte, eles sempre encontram alguém de sábias maneiras, benevolente em presentes, que deseja exaltar sua glória perante os guerreiros, a realizar feitos de valor, até que tudo se acabe, a luz e a vida juntas; aquele que faz o que é digno de honra tem a glória eterna sob os céus.] (Widsith , vv. 138-143)

Além desses dois poemas, como forma de descrição heróica, o mesmo conceito aparece também em diversos outros poemas anglo-saxões como forma de caracterização da figura heróica ${ }^{197}$; e, além disso, na própria Bíblia ${ }^{198}$.

Retornando a imagem dos três reis, podemos caracterizá-los dentro desse contexto de sapientia et fortitudo. O poema Beowulf pode ser dividido em duas partes respectivamente, sendo a Parte I marcada pela viajem de Beowulf a corte do rei Hrothgar da Dinamarca e, posteriormente, seu confronto contra Grendel; já a Parte II seria caracterizada pelo governo de paz do rei Beowulf e seu confronto fatal contra o dragão que devasta seu reino. Vamos nos ater a Parte I do poema, onde podemos identificar as imagens de sapientia et fortitudo. Desta maneira, podemos identificar o que já dissemos anteriormente a respeito das máximas, e também as passagens específicas que demonstram bem a relação de um Beowulf sábio e valente, um modelo heróico a ser seguido:

\footnotetext{
${ }^{197}$ André, vv. 624-625, 919, 1495-1497, 1577-1579; Guthlac, vv. 156-158, 184, 1109; Judite, vv. 145146, 333-334; Juliana, vv. 431-432; 547-551; Elena, vv. 934-935; Genesis, vv. 1151-1152; Exodo, vv. 12-14; Daniel, v. 666.

198 Jó 9, 4; 12, 12-13.16; 36, 22.26; 37, 23-24; Sl 89, 11-12; Pr 8,14; 16, 32; 21, 22; 24, 5-6; Sb 8, 15Ez 28, 4.5; Dn 2, 20.23.
} 
ne hyrde ic snotorlicor

on swa geongum feore guman pingian.

pu eart mægenes strang ond on mode frod

wis wordcwida.

[Nunca eu ouvi um homem falar de forma tão sábia. Você é poderoso em força e sábio em mente, grande orador.] (vv. 1841-1845) ${ }^{199}$.

Quando da cristianização dos anglo-saxões, podemos perceber uma clara identificação, ou “predileção”, do período para com o Velho Testamento ${ }^{200}$, em especial com os seus reis ${ }^{201}$, lutando contra os inimigos de Deus; o que de certa forma se encaixava bem com a imagem germânica do confronto dos homens e dos deuses contra os malignos gigantes ${ }^{202}$ e uma possível identificação com as tribos de Israel e com sua sociedade, muito mais do que com a sociedade de Roma ${ }^{203}$. Pois bem, na primeira parte do poema, temos uma figura que se encaixa na imagem dos antigos reis e patriarcas bíblicos: Hrothgar. O rei dos dinamarqueses, Hrothgar, é um homem de certa idade quando Beowulf chega a sua corte para ajudá-lo a se livrar do grande mal que o assombra. Após a vitória de Beowulf sobre Grendel e sua mãe,

\footnotetext{
${ }^{199}$ Ver as passagens que também tratam da mesma questão de sapientia et fortitudo : vv. 287-189; 260285; 349-350; 415-517; 440-445; 825-826; 974-977; 1219-1220; 1384-1389; 1474-1491; 1674-1676; 1705-1706; 1836-1839; 1826-1835; 2029-2069; 2178-2183.

${ }^{200}$ Tratando especificamente de Beowulf, é possível estabelecer certas relações e possíveis influências do mesmo com o texto do Velho Testamento. Por exemplo, temos a figura de Davi contra Golias, onde poderíamos fazer uma analogia com Beowulf contra Grendel. Outros paralelos também são com Sansão, Móises (como ele é apresentado no Êxodo do Codex Junius 11; poema em inglês antigo retratando o texto bíblico) e Judas Macabeu contra Nicanor (1Mc 7, 47 e principalmente 2Mc 15, 30-5. A relação desta passagem com Beowulf é interessante não apenas em relação a morte de Grendel, mas ao significado também; talvez a passagem do poema onde Grendel não pode se aproximar do trono de Hrothgar e a simbolismo de ter se levantado contra Heorot, possa ser comparado da mesma forma que Nicanor frente aos judeus). Além disso, no texto bíblico podemos relacionar com o poema a respeito da idéia da vitória concedida por Deus àqueles que são merecedores (como Beowulf lutando desarmado contra Grendel e sua mãe): 2Mc 15, 21; 1Sm 17, 47.Ver ORCHARD, pp. 145-147. É possível também uma certa influência latina. Apesar de ser considerado um debate ultrapassado desde o artigo de Tolkien em 1936, talvez a influência latina em Beowulf seja pertinente. Ao que parece, Virgilio era conhecido na Inglaterra anglo-saxônica. Um possível exemplo, ou paralelo, entre Beowulf e a Eneida seja numa passagem do VIII livro do último, a respeito da lenda do confronto entre Hércules e o monstro Caco, contado pelo rei Evandro. A similaridade temática da história é muito próxima: o herói que enfrenta uma criatura (homemmonstro) que habita numa caverna e que teria atacado as redondezas carregando seu butim para sua morada.

${ }^{201}$ Nas leis do rei Alfred, o Grande é possível notarmos a influência do Velho Testamento, ao utilizar a lei mosaica; o que nos permite reforçar a idéia que o rei-germânico é investido de poderes terrenos, mas também intercede com o divino, como Alfred que compila suas leis com base na lei sagrada. CHANEY, pp. 187-188.

${ }^{202}$ MAYR-HARTING, pp. 220

${ }^{203}$ CHANEY, pp. 174.
} 
Hrothgar faz grandes homenagens ao jovem herói e é nesse momento que desempenha seu papel mais importante, ao realizar seu sermão a Beowulf. A imagem de Hrothgar é justamente a do velho rei, que já não tem a mesma força como no passado, mas é possuidor de grande sabedoria; e é através de seu sermão que podemos vê-lo como o "rei sábio”. É interessante notar o modo como Hrothgar é tratado. Temos por exemplo os termos gamelum rince e harum hild-fruman. $\mathrm{O}$ primeiro termo significaria "homem (guerreiro) de idade (velho)", enquanto o segundo termo seria "grisalho líder-de-guerra"; ambos nos passam a idéia de um guerreiro idoso que (dentro do contexto do poema) envelheceu, e a palavra “grisalho” trás uma idéia de maturidade; ou seja um homem que já teve seus dias de fortitudo e que vive seus últimos dias com a sapientia.

Fazendo uma comparação, podemos dizer que nessa parte do poema, Hrothgar simbolizaria a plenitude da sapientia e o declínio de sua fortitudo, frente a um jovem Beowulf na plenitude de sua fortitudo. Aliás, devemos ressaltar que o único personagem dentro do poema que é citado tanto por sua sapientia quanto fortitudo é o próprio Beowulf. O sermão de Hrothgar é o grande exemplo do ideal aristocrático e, principalmente, de realeza; por todo ele é possível visualizar este forte modelo moralizante, em especial ao comparar Beowulf a figura do rei Heremod:

"Pæt la mæg secgan, se pe soð ond riht fremeð on folce, feor eal gemon, eald eðel-weard, pæ ðes eorl wære geboren betera! Blæd is aræred geond wid-wegas, wine min Beowulf, ðin ofer peoda gehwylce. $\quad$ Eal bu hit gepyldum healdest, mægen mid modes snyttrum. Ic pe sceal mine gelæstan freode, swa wit furðum spræcon. Đu scealt to frofre weorpan eal lang-twidig leodum binum hæleðum to helpe. Ne wearð Heremod swa eaforum Ecgwelan, Ar-Scyldingum; ne geweox he him to willan, ac to wæl-fealle ond to deað-cwalum Deniga leodum. 


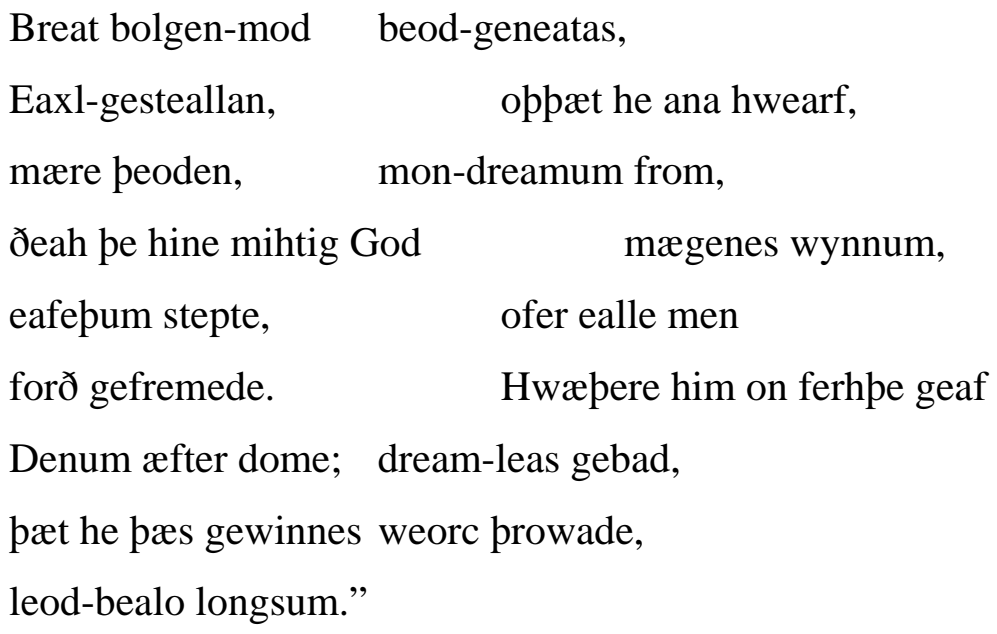

[Agora ele pode dizer, aquele que age de forma verdadeira / e correta para com seu povo, lembrando de nosso passado, / velho guardião de nossas terras: este príncipe nasceu / para ser grande! Seu glorioso nome / se ergue até as alturas sobre as nações, / Beowulf meu amigo, sua fama vai longe. / De forma adequada você controla sua força com sabedoria. / Lhe mantenho um voto como amigo, como disse anteriormente. / Serás de grande ajuda para teu povo, / um grandioso herói. Diferente de Heremod / com os filhos de Ecgwela, os honoráveis Scyldings; ao crescer não lhes trouxe alegrias, mas matou dinamarqueses / em seu próprio salão, de forma sangrenta. Tomado de fúria ele abateu seus companheiros, / até que exilado, sozinho, o famoso príncipe, / foi para longe da alegria de outros homens, com má reputação, / apesar de Deus ter-lhe conferido os méritos de uma grande força, / poderoso, sobre todos os homens. / Apesar de sua boa fortuna seus pensamentos tornaram-se vis, / seu coração sedento por sangue; nunca presenteou anéis, por honra, aos dinamarqueses. / Sem alegrias ele viveu e infeliz ele morreu, / sofrendo amargamente pelo mal que causou ao seu povo.] (vv. 1700 - 1722). 


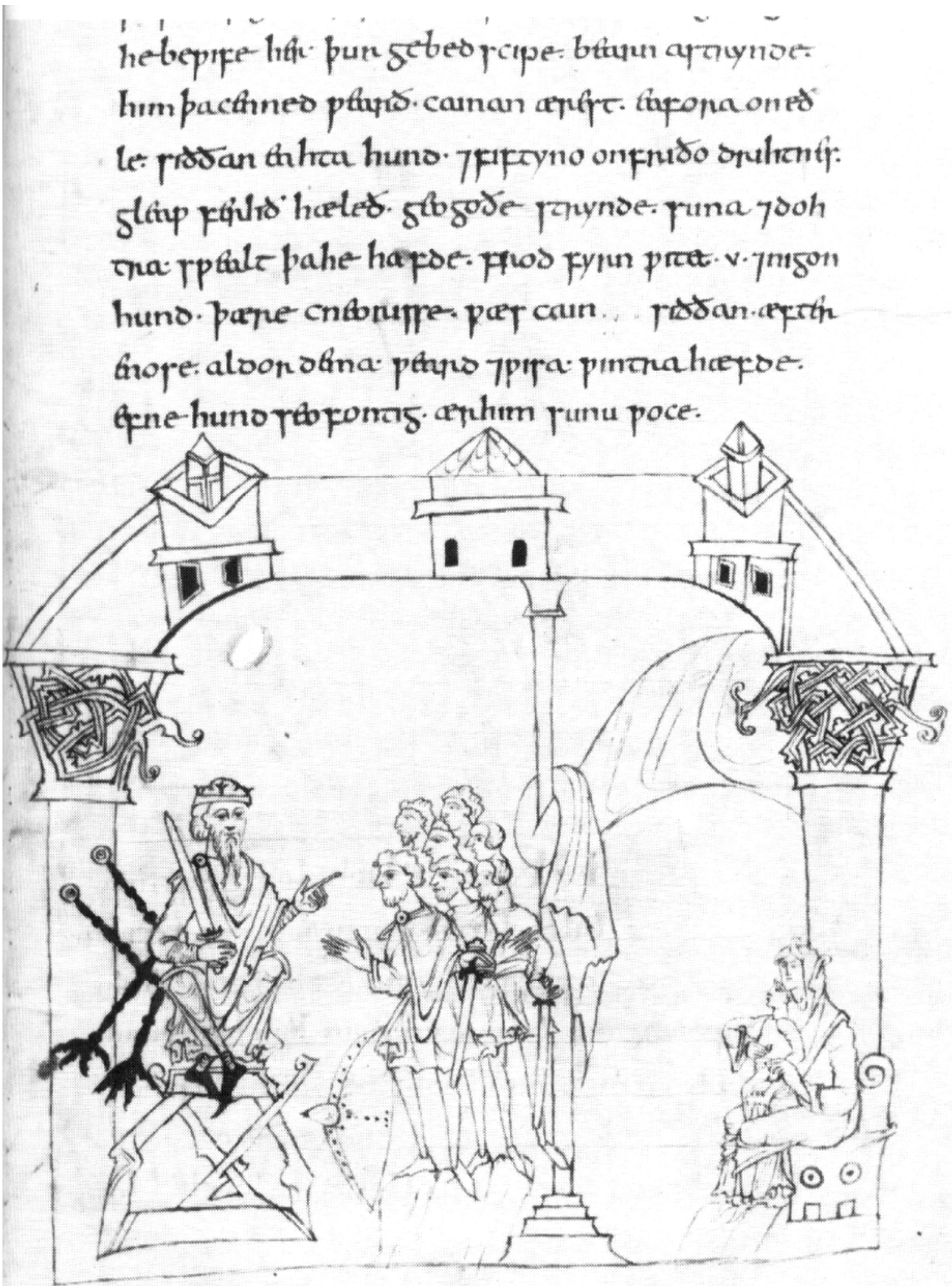

figura 10: Ilustração do poema Gênesis (Codex Junius II, fol. 57r), mostrando Caim sentado ao trono e cercado de seus guerreiros, ao mesmo estilo dos reis anglo-saxôes (e demais germânicos). [James Campbell. The Anglo-Saxons, Londres: Penguin, 1991, p. 213] 
Através deste trecho do poema, podemos observar a importância de Hrothgar como um rei sábio, mas também a presença da sapientia e fortitudo dentro de um modelo de realeza. O que o sermão nos mostra é um exemplo de um rei (Heremod) que padeceu pela falta de sapientia e acabou pagando amargamente por isso; enquanto Beowulf é tratado como um herói para seu povo, visto que no momento ele é possuidor de fortitudo a qual administra com sapientia,. Entretanto, Hrothgar, como foi dito antes, sofre pelo declínio de sua fortitudo, o que poderia ser refletido na ameaça de Grendel que por onze anos aterrorizou seu reino, até que Beowulf viesse ajudá-lo. Oposto a imagem do rei sábio, Hrothgar, teríamos a figura do rei vigoroso, forte. Essa figura de poder e força pode ser identificada em Hygelac, rei dos geats.

Hygelac, rei da tribo dos geats, dentro do modelo sapientia et fortitudo seria representante do último. Enquanto Hrothgar é o rei sabio, Hygelac é o rei forte. De certa forma poderíamos até mesmo ampliar essas definições para a população (lembrando do que dissemos anteriormente sobre o papel régio como mediador com o divino e responsável pelo bem estar de seu povo ${ }^{204}$ ). Desta forma, dentro do poema, os dinamarqueses como um todo simbolizariam a sapientia, enquanto os geats teriam fortitudo. Entretanto, enquanto Hrothgar (e os dinamarqueses) sofrem com os ataques de Grendel e sua incapacidade de enfrentar a criatura; Hygelac (e os geats) sofrem com as medidas tomadas em confronto contra os francos, o que leva a morte do rei dos geats. Ou seja, o que temos é a falta de sapientia:

Hyne wyrd fornam,
sypðan he for wlenco
fæhðe to Frysum.

[O Destino o levou / quando ele por orgulho buscou por problemas, guerra / contra os frísios]

(vv. 1205-1207)

Hygelac mais tarde realmente acaba morrendo em batalha no continente, e um dos únicos sobreviventes é justamente Beowulf. Mas a idéia é a de que Hygelac morre

${ }^{204}$ CHANEY, pp. 64-65, 71-72 
não devido a possíveis falhas ao combater, pelo contrario, ele é o exemplo do rei forte, vigoroso; sua morte, como mostra o trecho acima, é devido a seu orgulho, ou seja, a ausência de sapientia. O que podemos notar é um contraste que permeia o poema. Este contraste então ocorrerá não apenas num âmbito de sapientia e fortitudo, mas também de velhice e juventude, Hrothgar e Hygelac; contrastes que acabam por se unir numa única figura: Beowulf. Ele é a figura que inicia o poema jovem e detentor de grande fortitudo, e mais tarde demonstra sapientia como rei por governar de forma pacífica e prospera. Ou seja, o ideal de realeza é aquele que consegue combinar, ao mesmo tempo, sapientia e fortitudo. Este sim seria o ideal a ser alcançado de um governante bem sucedido; e como modelo dessa união bem sucedida temos a figura de Beowulf ${ }^{205}$. A forma como isso é representado no poema é através do duelo de Beowulf contra o dragão que ataca seu reino. Segundo a história, os geats viveram por mais de cinqüenta anos em paz devido ao governo de Beowulf, até que um dragão passa a devastar o reino. Ele então se prepara para enfrentar a criatura e parte para o covil do monstro. Neste momento, a imagem que temos é de um rei já envelhecido, porém vigoroso (pelo fato de estar indo defender seu povo e enfrentar o dragão) e sábio (ao relatar os acontecimentos passados, como o lamento do rei Hrethel; vv. 2425-2471). Nesse momento podemos ver claramente a união dos elementos sapientia e fortitudo na figura única de Beowulf ${ }^{206}$.

\footnotetext{
${ }^{205}$ O sucesso de Beowulf é demonstrado através da idéia do rei “mantenedor da paz”. Esta idéia estaria não apenas de acordo com um ideal germânico, mas também cristão. Basta lembrarmos do rei Hrothgar atormentado por Grendel e rei Beowulf, que por cinqüenta anos manteve a paz, mas com sua morte é anunciado tempos de incerteza e guerra. Isto explica as imagens de reis como Athelstan e Edgar como bons reis, por terem mantido a ordem no reino, e de Æthelred II como um péssimo rei, por ter permitido a invasão dos escandinavos. Ver CHANEY, pp. 91-94. Ou ainda também temos a carta de Alcuíno de York em 796, onde diz que "a morte de um rei é o sinal de tristezas". Ver WHITELOCK, 1964, pp. 88-89.

${ }^{206} \mathrm{Um}$ aspecto interessante a ser observado quanto a forma de Beowulf seria a "circularidade" do poema. No poema, a personagem de Beowulf, assim como Scyld Scefing, vem de além mar para salvar os dinamarqueses (Beowulf os salva de Grendel, enquanto Syld traz a paz a eles); o poema abre com o funeral de Scyld e termina com o funeral de Beowulf. Há uma repetição dos fatos, mas de forma ascendente e descendente (o que nos leva a circularidade): com Scyld se da uma ascendente (sua chegada após tempos conturbados, seu funeral que dá origem a uma grande linhagem, por exemplo) e já com Beopwulf é o oposto (demora a se tornar rei, não deixa uma linhagem e seu funeral anuncia tempos dificeis para os geats). Outro exemplo seria de em relação aos governos de Hrothgar e Beowulf. Em ambos temos a imagem do rei idoso e o jovem guerreiro leal: primeiro temos rei Hrothgar e o jovem Beowulf; mais tarde o rei Beowulf e o jovem Wiglaf, e também a duração de cada um dos reinados ser de exatamente cinqüenta anos. Ver ORCHARD, pp. 103-105.
} 


\section{III.4 - O modelo aristocratico: Beowulf}

O ideal heróico de Beowulf, como vimos, não se restringiria puramente como forma de entretenimento para os salões dos reis saxões. Além disso, sua função também seria moralizante no sentido de se tornar um ideal de aristocracia e de realeza. Através do sermão de Hrothgar temos a imagem do bom rei e do mau rei, e o mesmo se repete mais tarde com a história das rainhas Hygd, a boa rainha, e Modthrytho, a rainha má (Beowulf, vv. 1925-1962), onde a primeira é o exemplo de cortesia, sabedoria e honradez; enquanto a última representaria a vilania, malicia ${ }^{207}$. Vemos então que o poema se desenrola de maneira a sempre mostrar estes contrapontos, e sempre o herói Beowulf está posicionado como o melhor expoente dentre eles.

Este modelo aristocrático esta presente em toda a cultura germânica do período. Vimos que podemos encontrá-la em diversas outras fontes do mesmo âmbito; e se formos mais além, podemos encontrar similares em outras personagens de outras fontes e em outros períodos; desde as narrativas do ciclo arturiano, à Canção de Rolando, El Cid, até a narrativa de Heródoto sobre os 300 de Esparta e a batalha das Termópilas ${ }^{208}$. Entretanto, referente ao período ao qual estamos tratando,

\footnotetext{
${ }^{207}$ Talvez também haja uma relação deste episodio das duas rainhas, com o da rainha Eadburh, contido na Vida de Alfred, parágrafo 14-15. Eadburh teria sido uma má rainha, como Modthrytho, e que com a morte de seu marido teria fugido com todos os seus tesouros para a corte de Carlos Magno. Entretanto, ao chegar lá, ela foi enganada pelo senhor dos francos e enviada para um convento, onde passou o resto de seus dias na pobreza.

208 HERODOTO, livro 7: No sétimo livro da História, intitulado como Políminia, próximo ao seu fim, Heródoto descreve a localização de um desfiladeiro de nome Termópilas: "Então o rei Xerxes estava acampado em Malis, na Traquinia, e os helenos no desfiladeiro; esse lugar é chamado "Termopilas" pela maioria dos helenos, mas para os habitantes da região e seus vizinhos e seu nome é Pilai.". Neste local é que iria se desenrolar uma das batalhas mais conhecidas da Antiguidade.

$\mathrm{O}$ relato segue nos informando a respeito do número de homens posicionados na região e sua procedência. Mas já no parágrafo 203 encontramos um sinal do estilo característico da narrativa, ao se referir à figura de Xerxes: “203. (...) eles nada tinham a temer, pois a Hélade não estava sendo atacada por um deus, e sim por um homem; nunca houve e jamais haverá um mortal a quem desde a hora de seu nascimento não acontecessem desventuras, e quanto maiores os homens, maiores as desventuras (...)”. Esta passagem se encaixaria perfeitamente nas obras de Homero ou na Eneida de Virgílio. Em obras poéticas épicas ou heróicas, é característica a presença de máximas desse gênero que trazem reflexões sobre o mundo e a condição humana. Heródoto continua sua narrativa até que finalmente chegamos à personagem principal do episódio das Termópilas: "204. Todos os contingentes de tropas tinham à sua frente comandantes separados para cada povo, mas o mais importante, o comandante-em-chefe de todo o exército, era o lacedemônio Leônidas filho de Anaxandrides filho de Lêon filho de Euricratides filho de Anáxandros filho de Euricratides filho de Polídoros filho de Alcamenes filho de Têleclos filho de Arquêlaos filho de Hegesílaos filho de Doriscos filho de Leobotes filho de Equêstratos filho de Ágis filho de Euristenes filho de Aristôdemos filho de Aristômacos filho de Cleôdaios filho de Hilos filho de Héracles (...)”. A forma como Leônidas é introduzido na narrativa é típica de narrativas de outras
} 
Beowulf se diferencia das demais narrativa germânicas no sentido de que Beowulf pode ser caracterizado como a imagem ideal por excelência de uma sociedade aristocrática.

Através do próprio poema podemos perceber que os demais personagens são possuidores de certas qualidades, mas que é apenas Beowulf que consegue englobalas todas numa única figura. Ele passa por todas as imagens de importância durante o decorrer da história: inicialmente ele é um thane, um guerreiro leal a seu senhor, mas ao mesmo tempo ele também é um nobre, um príncipe (atheling), e mais tarde se torna rei (um rei que governa por mais de cinqüenta anos em paz e sem ataques externos, pois seus inimigos o temem). Ele possui todas as qualidades aristocráticas ideais encontradas em os Dons dos Homens e demais poemas, assim como os atributos pertencentes da realeza (sapientia et fortitudo).

Através desta analise de Beowulf, podemos ter não apenas uma visão da figura do herói e nem do rei, mas muito mais de uma sociedade aristocrática de cujo meio são criadas essas imagens. Imagens que permanecem mesmo dentro do seio da Igreja, pois existe uma documentação que comprova o gosto dos clérigos saxões pelas narrativas e poemas; o que não é de todo estranho de pensar, visto que a Igreja inglesa (anglo-saxã) seria uma Adelskirche, “igreja da nobreza”, de caráter claramente aristocrático.

Assim, o que podemos concluir seria de que o ponto chave do poema não seria essencialmente a figura do herói, nem da realeza, mas sim do mundo aristocrático no qual ele surgiu e de onde as figuras régias e heróicas tomaram

culturas, ao mostrar sua origem tendo como início uma figura mítica. Um exemplo disso pode ser encontrado na Crônica Anglo-Saxônica, como vimos anteriormente.

A resistência de Leônidas aos persas estava carregada de valores a serem seguidos pelos guerreiros que viessem depois dele. Mesmo frente ao destino inexorável, eles se mantiveram firmes em sua decisão de permanecer e lutar; e só foram derrotados devido a traição de Ephialtes. São diversos valores que se contrapõe: um rei bravo e honrado que escolhe a morte a entregar seu povo ao invasor; guerreiros valorosos que não abandonam seu senhor na batalha. Um exemplo sobre esta questão da lealdade para com o líder ocorre em Beowulf. Ao final do poema, quando o herói Beowulf morre logo após derrotar o dragão que ataca o reino, o jovem Wiglaf, o único a auxiliar seu senhor no confronto, se volta para os demais que se acovardaram: "Muitos poucos defensores/ posicionados em torno do rei quando sua pior hora chegou./Agora todos os tesouros, dados e recebidos,/ todas as alegrias do lar, posses, conforto/ deverão acabar para os seus; privados de seus direitos/, cada homem de suas famílias deverá ser exilado/ uma vez que nobres de longe ouviram de sua fuga,/um feito de nenhuma honra. A morte é melhor/ para qualquer guerreiro do que uma vida de vergonha!" (Beowulf, vv. 2882-2891). O mesmo espírito está presente na História, de Heródoto.

Em sua narrativa, Heródoto traz a personagem de Leônidas justamente como o rei-guerreiro de uma linhagem nobre (descendente de Héracles) e possuidor de valores de respeito e admiração. Podemos comparar a imagem de Leônidas e de seus guerreiros em Termópilas com a de Beowulf, do poema homônimo, e do poema a Batalha de Maldon. Em Maldon, assim como em Heródoto, os saxões sabiam de sua derrota certa e mesmo assim prosseguiram na batalha. 
forma, e a maneira como elas se relacionam. Seus valores e símbolos atuam como uma forma de incorporar o passado e o presente através de um comportamento e valores nobres, projetados em seus extremos de manifestações benignas e malignas, como num jogo de luz e sombra. O que temos em Beowulf é a construção de um mito social da cultura anglo-saxônica ${ }^{209}$, a construção de um passado mito-histórico que legitime o presente. Desta forma, ao analisarmos a sociedade anglo-saxônica através do poema, temos então a imagem de Beowulf como o ideal deste mundo aristocrático que pode ser representado pelos últimos versos do poema, onde podemos ver a presença dos três elementos que compõe este universo germânico idealizado num único personagem, nas figuras do rei, do guerreiro e do herói e das qualidades que lhe são naturais:

cwædon pæt he wære wyruld-cyning[a],

mannum mildust ond mon-ðwærust,

leodum liðost ond lof-geornost.

[Eles disseram que ele foi, dos reis deste mundo, / o mais justo para os seus homens, o mais cortês dos homens, / o melhor para seu povo, e o que mais buscou a glória] (vv. 3180-3182).

${ }^{209}$ HILL, 1998, p. 268. 


\section{CONCLUSÃO}

Beowulf é o grande monstro dos estudos sobre a Inglaterra anglo-saxônica, ou ao menos é assim que a tradição de estudos a seu respeito o fez ser. Nossa intenção aqui foi justamente tentar contribuir com mais uma proposta, uma possibilidade dentro de tantas outras que nos parece plausível para uma melhor compreensão da obra. O que tentamos demonstrar em nossa hipótese central foi da origem e intenção da composição de Beowulf. Acreditamos que longos debates a respeito da autoria, local de origem e uma possível origem pré-cristã não caberia neste trabalho, e também porque são assuntos inócuos os quais (com base no conjunto material que temos até então) é pouco provável de se chegar a qualquer conclusão em definitivo. Justamente por isso enveredamos pelo caminho da interpretação e importância documental frente a uma platéia de origem germânica da Alta Idade Média.

De forma alguma pretendemos por um ponto final sobre o assunto (mesmo porque, não o há como fazer no presente momento), mas acreditamos sim ter contribuído para uma melhor análise sobre o poema em relação ao período no qual se insere. Justamente por isso, ao invés de nos atermos a teorias literárias e modelos de pura análise lingüística e estilo, nos mantivemos muito mais focados com relação a seu aspecto histórico e significado, seguindo a corrente de Tolkien e Whitelock entre outros. E foi esse aspecto esse que se tornou o eixo central de nosso trabalho.

Desta forma, o que podemos detectar através de nossa hipótese seria que até o século IX na Inglaterra, assim como também no continente, temos uma tradição de origem germânica que terá grande e clara influência na produção cultural (tanto em prosa quanto em verso). Entretanto, a partir deste período há uma inovação dentro dessa produção cultural, iniciada justamente com o governo do rei Alfred, o Grande. Alfred era um homem letrado, traduziu diversas obras importantes para o inglês-antigo, e teria também dado início a uma produção poética de cunho heróico-cristão. Seu objetivo seria justamente estimular esse ideal na aristocracia anglo-saxônica, instigando em seus membros a retomada (ou para alguns o surgimento) de valores cristãos, mas ao mesmo tempo guerreiros. Isto nos faz lembrar as práticas dos primeiros missionários, que seguiam a ordem de Gregório o Grande, e se apropriavam dos elementos integrantes dos cultos pagãos em prol da fé cristã e principalmente direcionados para os reis (uma vez que o rei era o escolhidos dos deuses, onde a divindade do rei era a divindade da tribo); 
mas no caso de Alfred, a intenção não era a conversão, mas sim a criação de um ideal social dentro de sua aristocracia, responsáveis pela liderança das tropas e da defesa do reino, grupo de importância decisiva para a sobrevivência do reino. Este ideal se perpetuará com os descentes de Alfred, atingindo seu ápice com Athelstan ao tornar-se “senhor de toda a Inglaterra”, o primeiro bretwalda desde os tempos lendários das migrações para a antiga província romana.

Durante esse período, chamado por nós de período alfrediano, surgiram diversas produções poéticas com esse estilo de um ideário heróico. Mas não estamos dizendo que apenas com Alfred é que tal estilo surge na Inglaterra. O mesmo já existia nas sagas escandinavas e nas narrativas do continente. O que dizemos é que, o estilo heróico, como se apresenta em Beowulf e demais documentos, é incentivado justamente no período alfrediano devido às condições sócio-políticas do período (as invasões escandinavas, a relação com a Danelaw, a reconquista de tais territórios, um maior desenvolvimento e florescimento cultural e etc.).

O surgimento de tal obra, como Beowulf, segundo nossa hipótese, seria fruto de uma tradição de narrativas que existiam muito provavelmente desde o período das migrações (século V e VI) e com o passar do tempo foi se modificando, sendo adaptada; novos elementos sendo incluídos em sua trama, talvez até mesmo narrativas antes independentes acabaram sendo amalgamadas num único corpo de texto (o que corresponderia às teorias de uma estrutura dupla, tríplice ou múltipla do poema por alguns pesquisadores ${ }^{210}$ ). A influência de elementos escandinavos é muito provável também, devido ao período das invasões no século IX. Entretanto, toda está “evolução” do poema teria se concretizado com o surgimento do ideal forjado com o período alfrediano. Neste momento, o poema Beowulf acabaria por tomar a forma como conhecemos, refletindo o mundo aristocrático de uma Inglaterra pós-invasões vikings e se reerguendo sob a liderança da Casa de Wessex.

Desta forma, Beowulf não teria surgido como mera forma de propaganda da Casa de Wessex, como forma de legitimação de poder sobre as populações escandinavas, ou sido elaborado especialmente para um propósito como esse. Na verdade, o poema (assim como outros) teria surgido como um reflexo deste período. Ou seja, Beowulf não foi a causa de um ideal para a sociedade anglo-saxônica da Inglaterra, mas sim uma conseqüência da mesma. Apesar de seus aspectos modelares, não teria

\footnotetext{
${ }^{210}$ SHIPPEY, 1998, pp. 149-174.
} 
sido o herói Beowulf a moldar a aristocracia da Inglaterra, mas sim este mesmo grupo é que o moldou como um ideal. Ideal este que representava as aspirações de um mundo cristão-germânico que girava em torno de figuras heróicas, dos thegns, líderes guerreiros e reis, e representada para os mesmos através de uma obra poética como Beowulf.

Talvez esteja justamente nesta idéia, de uma obra poética, em seu aspecto artístico, que os futuros trabalhos a respeito de Beowulf devessem se basear:

"The future of Beowulf studies, I suspect, will not belong to those who just read the text, in the narrow sense of interpreting it. It will lie with those who also use and take pleasure in it, adapting it to their own purposes in the world in which they live, as the poet's own listeners and readers surely did.”211

${ }^{211}$ BJORK \& NILES, 1998, p. 11: "O futuro dos estudos de Beowulf, eu suspeito, não pertencerá àqueles que apenas lêem o texto, no sentido estrito de interpretá-lo. Ele estará com aqueles que também o usam $e$ tem prazer com ele, adaptando-o a seus próprios propósitos no mundo no qual vivem, assim como os próprios ouvintes e leitores do poeta certamente fizeram". 


\section{APÊNDICES}




\section{APÊNDICE I - Corpo Poético da Inglaterra Anglo-Saxônica}

Para uma melhor compreensão do que se trata a obra poética do período anglo-saxão da Inglaterra, relacionamos abaixo os títulos dos poemas traduzidos para o português. Com isso temos a intenção de regularizar a forma de suas traduções, visando trabalhos futuros (os títulos entre colchetes correspondem às formas originais mais comumente encontradas em bibliografia de língua inglêsa). A relação abaixo segue a seleção e organização encontrada na obra de S. A. J. Bradley, Anglo-Saxon Poetry, Londres, Everyman, 2003.

Hino de Cæedmon [Cædmon's Hymn]

A Inscrição da Cruz de Ruthwell [The Ruthwell Cross Inscription]

Canção da Morte de Beda [Bede’s Death-song]

\section{CODEX JUNIUS XI}

Gênesis [Genesis]

Exodo [Exodus]

Daniel [Daniel]

Cristo e Satã [Christ and Satan]

\section{O LIVRO VERCELLI}

André [Andreas]

O Destino dos Apóstolos [The Fate of the Apostles]

O Sonho da Cruz [The Dream of the Rood]

Elena [Elene]

\section{O LIVRO DE EXETER}

Cristo I (O Advento) [Christ I]

Cristo II (A Ascensão) [Christ II] 
Cristo III (O Julgamento) [Christ III]

Guthlac A [Guthlac A]

Guthlac B [Guthlac B]

Azarias [Azarias]

A Fênix [The Phoenix]

Juliana [Juliana]

O Andarilho [The Wanderer]

Os Dons dos Homens [The Gifts of Men]

Preceitos [Precepts]

O Navegante [The Seafarer]

Vanglória [Vainglory]

Widsith [Widsith]

As Fortunas dos Homens [The Fortunes of Men]

Máximas I [Maxims I]

A Ordem do Mundo [The Order of the World]

O Poema Rimado [The Rhyming Poem]

A Pantera [The Panther]

A Baleia [The Whale]

A Perdiz [The Partridge]

Alma e Corpo II [Soul and Body II]

Deor [Deor]

Wulf e Eadwacer [Wulf and Eadwacer]

Advinhações 1-59 [Riddles 1-59]

Advinhações 3, 5, 9, 25, 26, 29, 30a, 35, 38, 42-8, 53 [Riddles 3, 5, 9, 25, 26, 29, 30a,

35, 38, 42-8, 53]

O Lamento da Esposa [The Wife's Lament]

O Dia do Julgamento I [Judgment Day I]

Resignação [Resignation]

A Descida ao Inferno [The Descent into Hell]

A Doação de Donativos [Alms-giving]

Faraó [Pharaoh]

A Oração do Senhor I [The Lord's Prayer I]

Fragmento Homilético II [Homiletic Fragment II]

Advinhações 30b [Riddles 30b] 
Advinhações 60 [Riddles 60]

A Mensagem do Marido [The Husband’s Message]

A Ruína [The Ruin]

Advinhações 61-95 [Riddles 61-95]

Advinhações 61, 66, 69, 76, 86 [Riddles 61, 66, 69, 76, 86]

\section{COTTON VITELLIUS A XV}

Beowulf [Beowulf]

Judite [Judith]

\section{OUTROS}

A Batalha de Finnsburh [The Battle of Finnsburh]

Waldere [Waldere]

Máximas II [Maxims II]

A Batalha de Brunanburh [The Battle of Brunanbuhr]

A Batalha de Maldon [The Battle of Maldon]

O Dia do Julgamento II [The Judgment Day II]

O Ofício Beneditino: A Oração do Senhor; O Credo; Fragmento dos Salmos [The Benedictine Office: The Lord's Prayer; The Creed; Fragment of the Psalms]

Os Encantamentos Métricos: para as terras infrutíferas; um encantamento de viagem. [The Metrical Charms: for unfruitful land; a journey charm] 


\section{APÊNDICE II - Mapa da Inglaterra Anglo-Saxônica, século IX.}

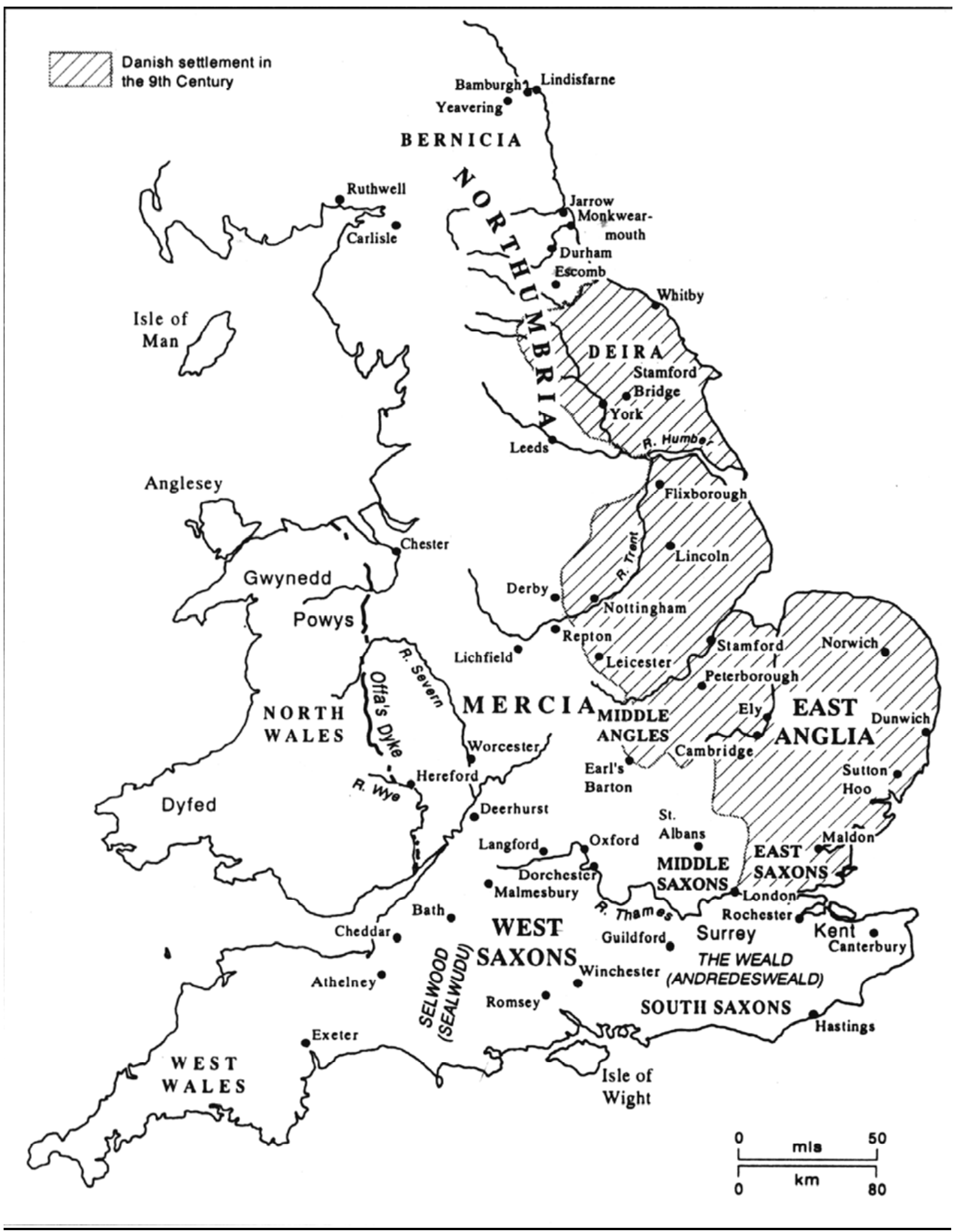

figura 11: Este mapa representa de forma geral a Inglaterra do período de Alfred, monstrando os principais pontos da Inglaterra anglo-saxônica e da região ocupada pelos escandinavos, a Danelaw (representada no mapa pela região listrada). [Bruce Mitchell. An invitation to Old English and AngloSaxon England, Oxford: Blackwell,1997, p. XX]. 


\section{APÊNDICE III - Guerreiros}

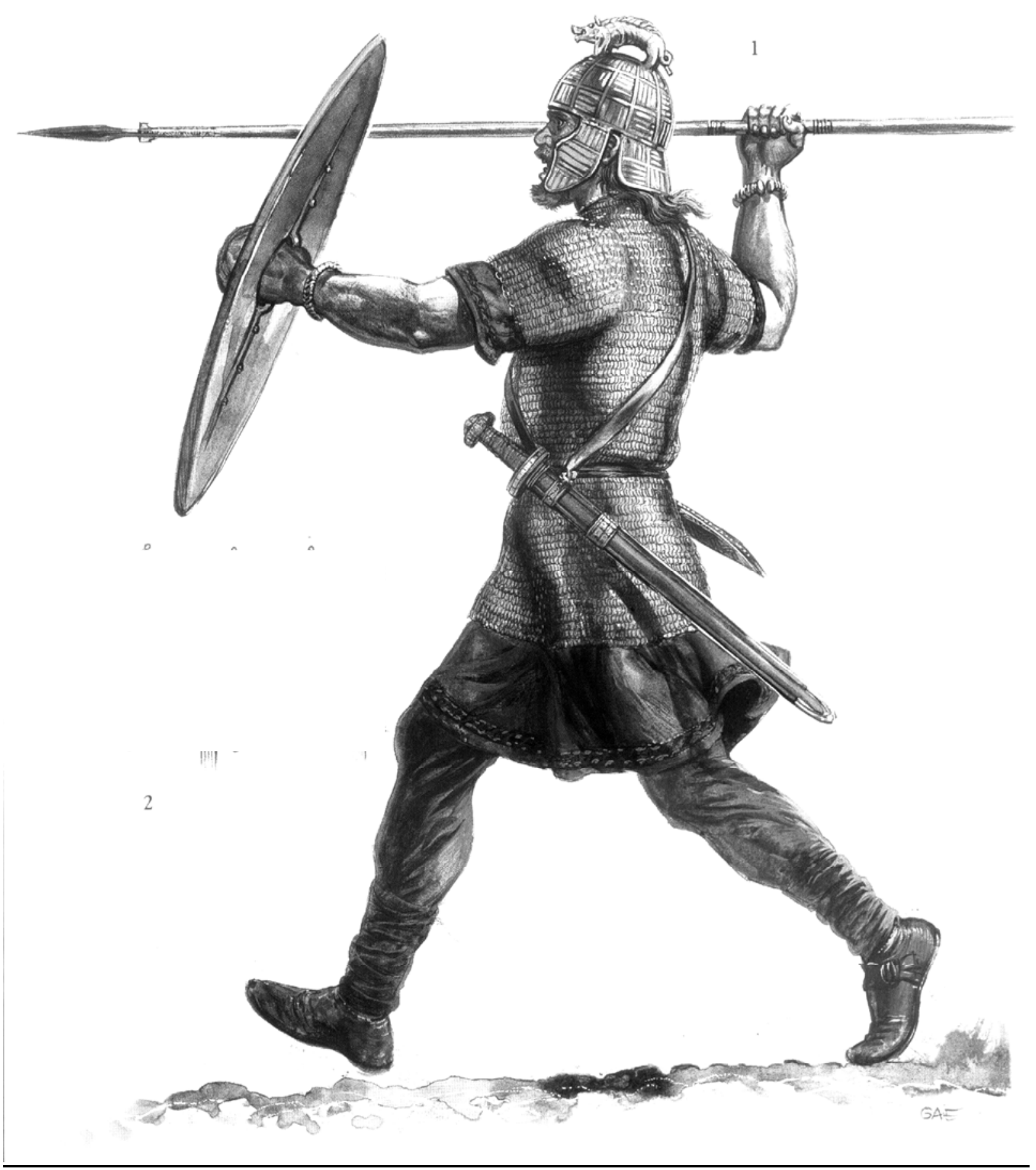

figura 12: Representação de um guerreiro escandinavo dos séculos VI - VII. Esta seria uma imagem muito próxima a descrição do equipamento das personagens de Beowulf, segundo as descrições encontradas no poema. [Mark Harrison. Viking Hersir: 793-1066 A.D., Londres: Osprey, 1996, p. 33]. 


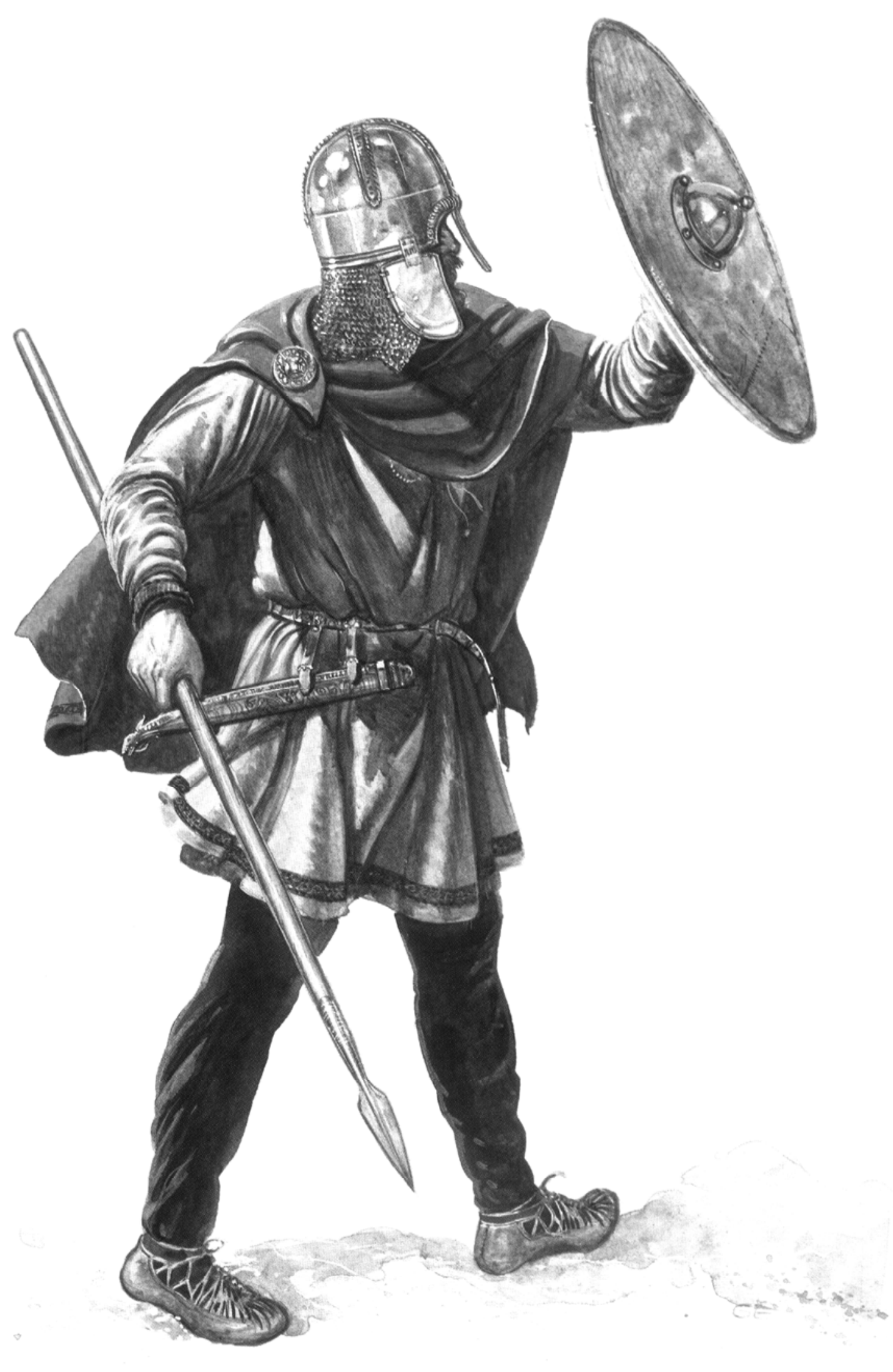

figura 13: Representação de um guerreiro anglo-saxão (um thegn) de meados do século VIII até início do século X. [Mark Harrison. Anglo-Saxon Thegn, AD 449-1066, Londres: Osprey, 2004, p. 35]. 


\section{APÊNDICE III - Genealogia da Casa de Wessex}

A genealogia que aqui apresentamos foi baseada nas genealogias encontradas nas obras de Michael Swanton (trad. e org.) The Anglo-Saxon Chronicle, Londres: Dent, 1997; Dorothy Whitelock. The Anglo-Saxon Chronicle, London, 1961; Douglas Woodruff. The Life and Times of Alfred the Great, Londres: Weidenfeld and Nicolson, 1993. 


\section{Legenda:}

\section{rei de Wessex}

\section{rei da Inglaterra}

f. - filha

m. - morreu em

= - matrimônio

r. - rei de

e. - ealdorman

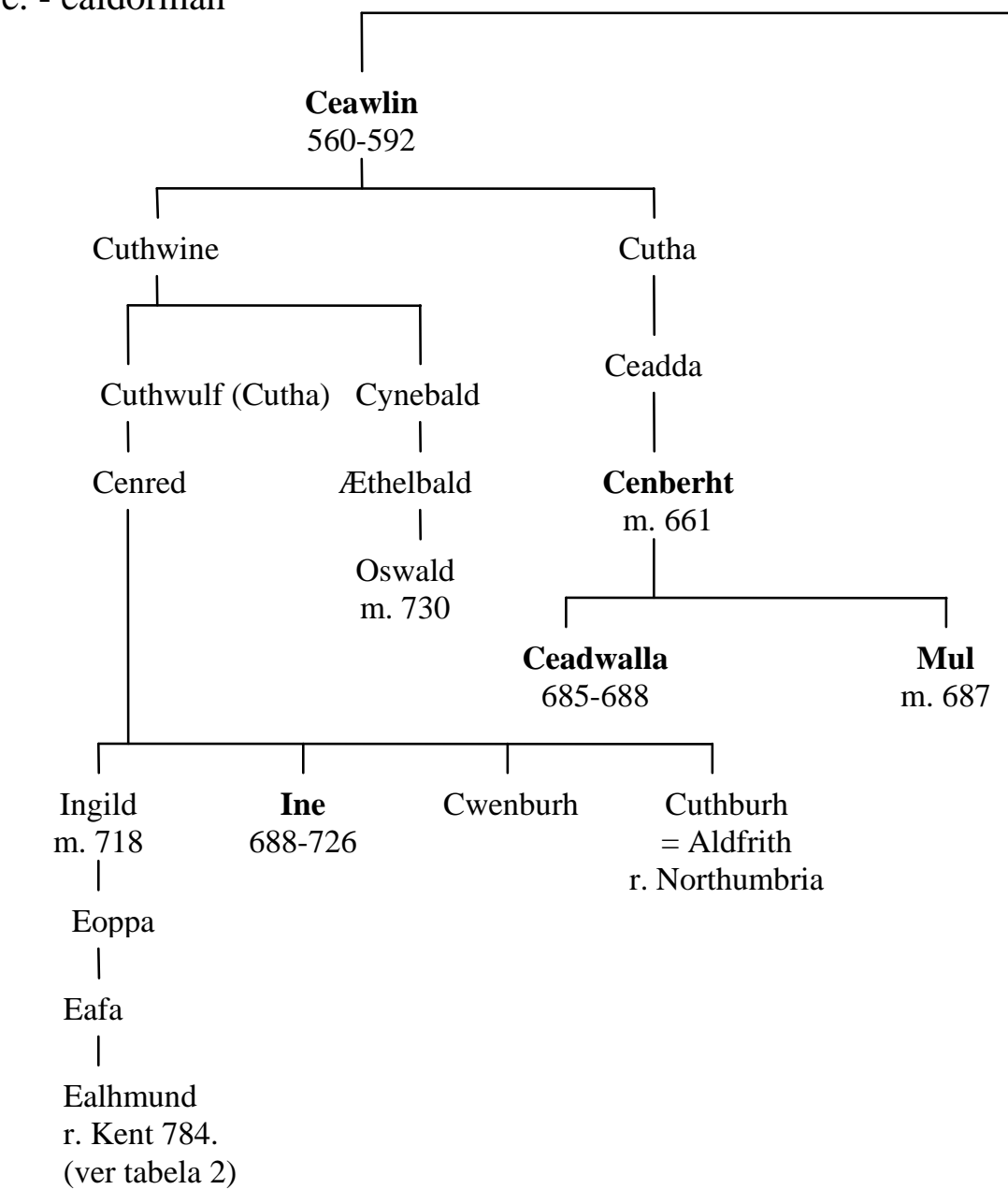

Cerdic,

Fundador e rei

de Wessex.

Tabela 1

Morreu em 534
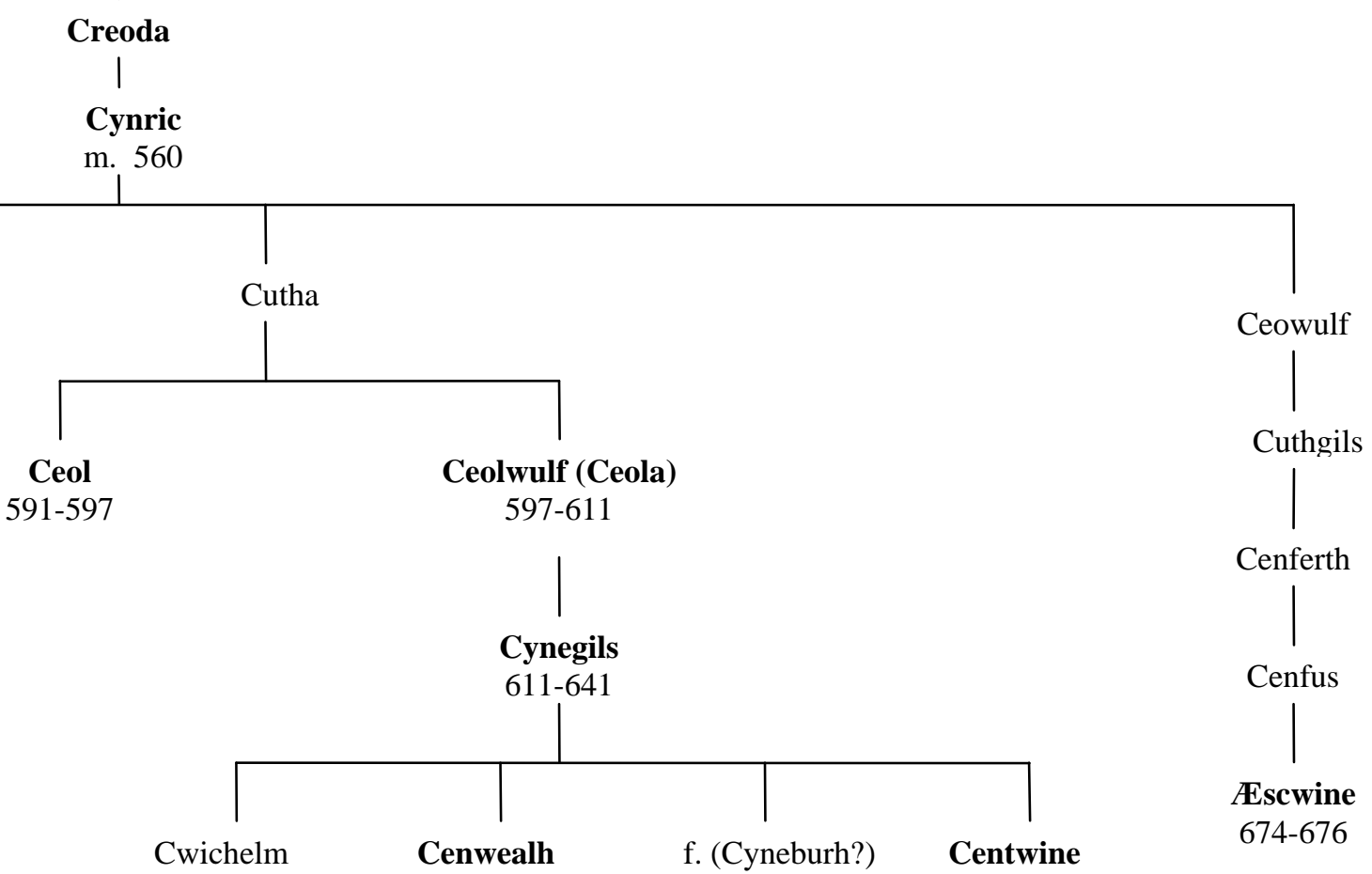


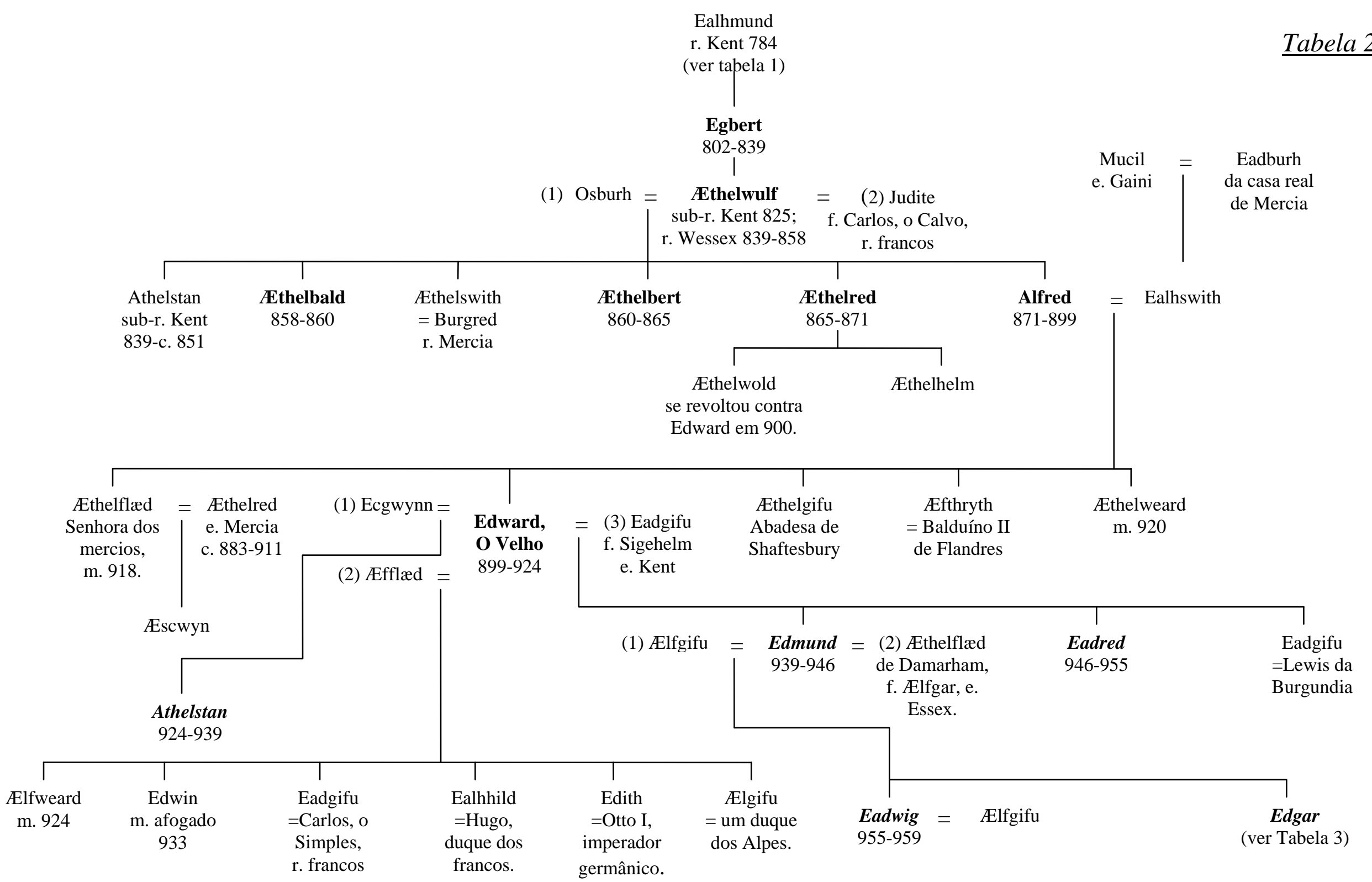




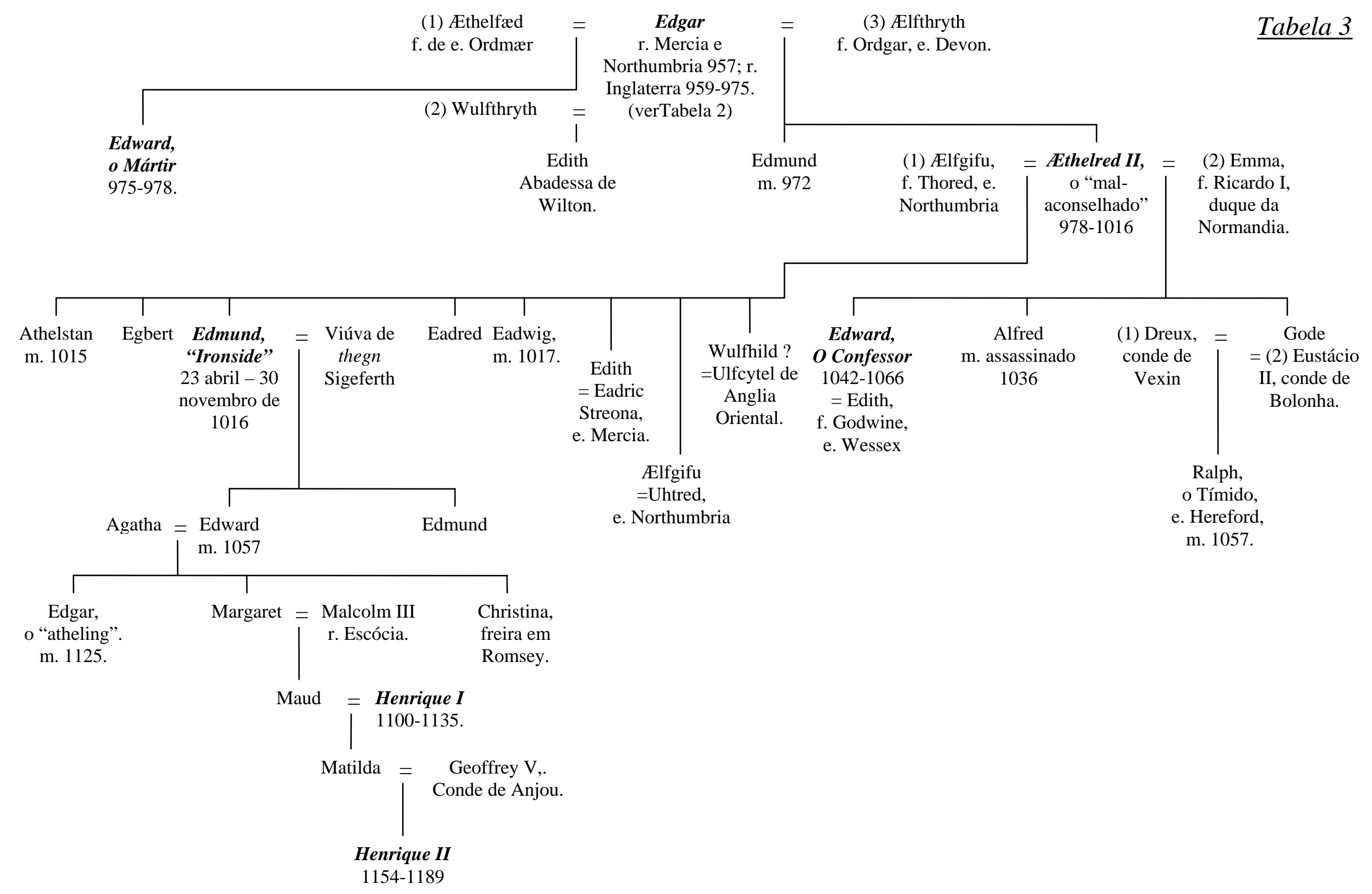




\section{Referências Bibliograficas}

\section{Fontes Primárias}

ALEXANDER, Michael (ed. org) Beowulf: A Glossed Text, Londres: Penguin, 2000.

BEDE. Ecclesiastical History of English People, Londres: Penguin, 1990.

BRADLEY, S.A.J. (trad. org.) Anglo-Saxon poetry, Londres: Everyman, 2003.

BYOCK, Jesse L. (trad.) The saga of king Hrolf Kraki, Londres: Penguin, 1998. The saga of the Volsungs, Londres: Penguin, 1999.

CAMPBELL, Alistair (ed. trad.) Chronicon Athelweardi, Londres: Thomas Nelson \& Son, 1962.

CHARLES, R. H. (trad.) The Book of Enoch, Boston: Weiser Books, 2003.

CHICKERING Jr., Howell D. (trad.) Beowulf, Nova York: Anchor Books, 1989.

DIAMOND, Robert E. (trad. org.) Old English: Grammar and Reader, Detroit: Wayne State University Press, 1999.

FARMER, D. H. \& WEBB, J. F. (trad. ed.) The Age of Bede, Londres: Penguin, 2004.

GALVÃO, Ary Gonzalez (trad.) Beowulf, São Paulo: Hucitec, 1992.

HEANEY, Seamus (trad.) Beowulf, Nova York: W. W. Norton, 2000.

HARRISON, Robert (trad.) The Song of Roland, Nova York: Signet Classic, 2002.

HERODOTO, História, Brasília: Ed. UNB, 1988.

HOLLANDER, Lee M (trad.) The Poettic Edda, AustIn: Texas University Press, 2000.

HOLLISTER, C. Warren (trad.) Njal's Saga, Kent: Wordsworth, 1998.

HUGHES, Ted. (org.) The sagas of the the Icelanders, Londres: Penguin, 2000.

JONIN, Pierre (trad.) La Chanson de Roland, Saint-Amand: Gallimard, 2004.

KEYNES, Simon \& LAPIDGE, Michael (trad. e org.) Alfred the Great: Asser's life of King Alfred and other contemporary sources, Londres: Penguin, 1983.

KEYNES, Simon (trad.) Encomium Emmae Reginae, Cambridge, Cambridge University Press, 1998.

KLAEBER, Frederick (ed.) Beowulf and the Fight at Finnsburg, Boston: D. C. Heath, 1950.

MITCHELL, Bruce \& ROBINSON, Fred C. (ed. e org.) Beowulf, Oxford: Blackwell, 1998.

MURPHY, G. Ronald (trad.) The Heliand, Oxford: Oxford University Press, 1992.

PORTER, John (trad.) Beowulf, Norfolk: Anglo-Saxon Books, 2003. 
PROENÇA, Eduardo de (org.) Apócrifos da Bíblia e pseudo-epígrafos, São Paulo: Fonte Ed., 2005.

PRUDENCIO Psychomachia, Bryn Mawr: Bryn Mawr Commentaries, 2004.

STURLUSON, Snorri. Heimskringla or the lives of the Norse kings, Nova York: Dover, 1990. Edda, Londres: Everyman, 1998.

SWANTON, Michael (trad. e org.) The Anglo-Saxon Chronicle, Londres: Dent, 1997.

TACITUS. The Agricola and the Germania, Londres: Penguin, 1970.

TOURS, Gregory of. The History of the Franks, Londres: Penguin, 1974.

WELLER, Shane (ed.) Beowulf, Nova York: Dover, 1992.

WHITELOCK, Dorothy (trad. e org.) English Historical Documents, Londres, 1955. The Anglo-Saxon Chronicle, London, 1961.

WRIGHT, David (trad.) Beowulf, Londres: Penguin, 1957.

\section{Fontes Secundárias}

ABELS, Richard P. Lordship and Military Obligation in Anglo-Saxon England, Berkeley: UCLA Press, 1998.

AUERBACH, Erich. Mimesis, São Paulo: Perspectiva, 2004.

BEHEIM-SCHWARZBACH, Martin. Sagas de heróis e cavaleiros, vol. I-II, Rio de Janeiro: Paz e Terra, 1997.

BARNES, Daniel R. "Folktale morphology and the structure of Beowulf”. Speculum 3, 1970, p. 416-434.

BJORK, Robert E. \& NILES, John D. A Beowulf Handbook, Lincoln: Nebraska University Press, 1998.

BJORK, Robert E. \& OBERMEIER, Anita. "Date, Provenance, Author, Audience” in: BJORK \& NILES, 1998, pp. 13-34.

BLACKBURN, F. A. “ The Christian Coloring in the Beowulf”, PMLA 12, pp. 205-225, 1897 In: NICHOLSON, 1966, pp. 1-22.

BLAIR, Peter Hunter. An introduction to Anglo-Saxon England, Cambridge: Cambridge University Press, 1959.

Roman Britain and Early England 55BC-AD 871, Nova York: W. W. Norton, 1966.

The World of Bede, Cambridge: Cambridge University Press, 1991.

The Church in the Anglo-Saxon Society, Oxford: Oxford University Press, 2005.

BLOCH, Marc. Feudal Society, vol. I - II, Chicago: Chicago University Press, 1994. 
Os Reis Taumaturgos, São Paulo: Cia. das Letras, 1998.

BLOOMFIELD, Morton W. “Beowulf and the Christian Allegory: An Interpretation of Unferth”, Traditio 7, 1949-1951, pp. 410-415 In: NICHOLSON, 1966, pp. 155-164.

"Beowulf, Byrhtnoth and the Judgement of God: trial by combat in Anglo-Saxon England”. Speculum 44/4, 1969, p. 545-559.

BORGES, Jorge Luis. Curso de Literatura Inglesa, São Paulo: Martins Fontes, 2002. Literaturas germánicas medievales, Madrid: Alianza Editorial, 2005.

BOSTOCK, J. Knight. A Handbook on Old High German Literature, Oxford: Clarendon Press, 1976.

BRONDSTED, Johannes. Os vikings, São Paulo: Hemus, 1988.

BUHL, Trine. "Premises of Literary History: On Genre and Narrative Modes in the Sagas”, Brathair vol. 4(2), 2004, pp. 4-16 (http://www.brathair.com).

CAMPBELL, James. The Anglo-Saxons, Londres: Penguin, 1991.

CAMPBELL, Joseph. O poder do mito, São Paulo: Palas Athena, 1990. As máscaras de Deus: mitologia primitiva, São Paulo: Palas Athena, 1992. As máscaras de Deus: mitologia oriental, São Paulo: Palas Athena, 2002. As máscaras de Deus: mitologia ocidental, São Paulo: Palas Athena, 2004. O herói de mil faces, São Paulo: Palas Athena, 2000. Mitologia na Vida Moderna, Rio de Janeiro: Rosa dos Ventos, 2002.

CARVER, Martin. Sutton Hoo: Burial ground of kings?, Londres: British Museum Press, 1998.

CATHEY, James E. Hêliand: Text and Commentary, Morgantown: West Virginia University Press, 2002.

CAVILL, Paul. Anglo-Saxon christianity, Londres: Fount, 1999.

CHADWICK, H. Munro. “The Heroic Age, an excerpt”, Nova York: Cambridge University Press, 1912, pp. 47-56 In: NICHOLSON, 1966, pp. 23-34.

CHANEY, William A. The Cult of Kingship in Anglo-Saxon England, Manchester: Manchester University Press, 1999.

CHASE, Collin. The Dating of Beowulf, Toronto: Toronto University Press, 1997.

CHURCHILL, Winston S. História dos povos de língua inglesa, vol. I, São Paulo: Ibrasa, 2005.

COATES, Simon. “The bishop as benefactor and civic patron: Alcuin, York and episcopal authority in anglo-saxon England”. Speculum 71/3, 1996, p. 529-558.

COHAT, Yves. The Vikings: lords of the sea, Nova York: Thames \& Hudson, 1999.

CORNWELL, Bernard. The Last Kingdom, Londres: Harper Collins, 2005. 
CROSSLEY-HOLLAND, Kevin. The Anglo-Saxon World, Oxford: Oxford University Press, 1999.

The Norse myths, Nova York: Pantheon, 1980.

CURTIUS, Ernst Robert. Literatura Européia e Idade Média Latina, São Paulo: Hucitec, 1996.

DAVIDSON, H. R. Myths and Symbols in the Pagan Europe, Syracuse: Syracuse University Press, 1988.

Gods and myths of the northern Europe, Londres: Penguin, 1990.

DIXON-KENNEDY, Mike. European Myth and Legend, Londres: Blandford, 1997.

DOANE, A.N. \& PASTERNACK, C. B. Vox Intexta: Orality and Textuality in the Middle Ages, Madison: Winsconsin University Press, 1991.

DUCKETT, Eleanor Shipley. Alfred the Great, the king and his England, Chicago: Chicago University Press, 2000.

DUMÉZIL, George. Do mito ao romance, São Paulo: Martins Fontes, 1992.

ELIADE, Mircea. Mito e Realidade, São Paulo: Perspectiva, 1972.

FLETCHER, Richard. The Barbarian Conversion, California: Henry Holt, 1999.

Bloodfeud: murder and revenge in Anglo-Saxon England, Londres: Penguin, 2003.

GODDEN, Malcolm \& LAPIDGE, Michael. The Cambridge companion to Old English Literature, Cambridge: Cambridge University Press, 1994.

GODFREY, John. The church in Anglo-Saxon England, Cambridge: Cambridge University Press, 1962.

GOLDSMITH, Margareth E. “The Christian Perspective in Beowulf”, Comparative Literature 14, 1962, pp. 71-80 In: NICHOLSON, 1966, pp. 373-386.

GRAHAM-CAMPBELL, James. Cultural atlas of the Viking world, Nova York: Facts on File Inc. 1996.

GRANT, John. An introduction to Viking mythology, Nova York: Shooting Star Press, 1996.

GREENFIELD, Stanley B. \& CALDER, Daniel G. A New Critical History of Old English Literature, Nova York: New York University Press, 1986.

GUERBER, H. A. Myths and legends of the Norsemen, Nova York: Dover, 1992. Myths and legends of the Middle-Ages, Nova York: Dover, 1992.

HALL, J. R. Clark. A concise Anglo-Saxon dictionary, Toronto: Toronto University Press, 1960. HAMILTON, Marie Padgett. “The Religious Principle in Beowulf”, PMLA 61, 1946, pp. 309-331 In: NICHOLSON, 1966, pp. 105-136.

HARRISON, Mark. Viking Hersir: 793-1066 A.D., Londres: Osprey, 1996. 
HARRISON, Mark. Anglo-Saxon Thegn, AD 449-1066, Londres: Osprey, 2004.

HAYWOOD, John. The Penguin atlas of the Viking world, Londres: Penguin, 1995.

HEINZ-MOHR, Geard. Dicionário dos Símbolos: Imagens e sinais da arte cristã, São Paulo: Paulus, 1994.

HILL, John. The Anglo-Saxon Warrior Ethic: Reconstructing Lordship in Early English Literature, Gainesville: Florida University Press, 2000.

HILL, M. John. “The Social Milieu” In: BJORK \& NILES, 1998, pp. 255-270.

HILL, Paul. The Age of Athelstan, Stroud: Tempus, 2004.

HILL, Thomas D. “Rigspúla: Some Medieval Christian Analogues”, Speculum, 61/1, 1986, pp. 79-89.

HODGKIN, R. H. A History of the Anglo-Saxons, vol. I-II, Oxford: Oxford University Press, 1967.

HOLLISTER, C. Warren. Anglo-Saxon military institutions, Oxford: Oxford University Press, 1962.

HOLMES, Georges. The Oxford Illustrated History of Medieval Europe, Oxford: Oxford University Press, 1990.

JOHN, Eric. “The Age of Edgar” In: CAMPBELL, 1991, pp. 160-191.

JONES, Gwyn. Kings, beasts and heroes, Oxford: Oxford University Press, 1972.

A History of the Vikings, Oxford: Oxford University Press, 1984.

JONES, Prudence \& PENNICK, Nigel. A History of the Pagan Europe, Londres: Routledge, 1995.

KANTOROWICZ, Ernst H. Os Dois Corpos do Rei, São Paulo: Cia. das Letras, 1998.

KASKE, R. E. “Sapientia et Fortitudo as the controlling theme of Beowulf”, Studies in Philology 55, 1958, pp. 423-457 In: NICHOLSON, 1966, pp. 269-310.

“Beowulf and the Book of Enoch”. Speculum, 46/3, 1971, p. 421-431.

KER, Niel R. Catalogue of Manuscripts Containing Anglo-Saxon, Oxford: Clarendon Press, 1957.

KIERNAN, Kevin. “The Eleventh-Century Origin of Beowulf and the Beowulf Manuscript” In: CHASE, 1997, pp. 9-22.

Beowulf and the Beowulf Manuscript, Michigan: Michigan University Press, 1999.

LAPIDGE, Michael. The Blackwell Encyclopaedia of Anglo-Saxon England, Oxford: Blackwell, 2004.

LE GOFF, Jacques. Dicionário temático do ocidente medieval, São Paulo: EDUSC, 2002. 
A Civilização do Ocidente Medieval, São Paulo: EDUSC, 2005.

LERER, Seth. "Beowulf and Comtemporary Critical Theory” In: BJORK \& NILES, pp. 329330.

LOYN, Henry. The Vikings in Britain, Oxford: Blackwell, 1994.

Dicionário da Idade Média, Rio de Janeiro: Jorge Zahar, 1997.

MACMULLEN, Ramsay. Christianity and paganism in fourth to eighth centuries, Yale: Yale University Press, 1997.

MALONE, Kemp. “Beowulf”, English Studies 29, 1948, pp. 161-172 In: NICHOLSON, 1966, pp. 137-154.

MARSDEN, Richard. The Text of the Old Testament in Anglo-Saxon England, Cambridge: Cambridge University Press, 1995.

MAYR-HARTING, Henry. The coming of christianity to Anglo-Saxon England, Avon: Penn State Press, 1994.

MELEIRO, Maria Lucília F. A mitologia dos povos germânicos, Lisboa: Ed. Presença, 1994.

MITCHELL, Bruce. An invitation to Old English and Anglo-Saxon England, Oxford: Blackwell,1997.

A guide to Old English, Oxford: Blackwell, 1999.

MOFFAT, Douglas. “Anglo-saxon scribes and Old English verse”, Speculum 67/4, 1992, p. 805827.

MURRAY, Alexander C. "Beowulf, the Danish invasions, and royal genealogy” In: CHASE, 1997, pp. 101-112.

MURPHY, G. Ronald. The Saxon Savior, Oxford: Oxford University Press, 1995.

NICHOLSON, Lewis E. “The literal meaning and symbolic structure of Beowulf”. Classica et Mediaevalia 25, 1964, p. 151-201.

An Anthology of Beowulf Criticism, Indiana: Notre Dame University Press, 1966.

NILES, John D .“Myth and History” In: BJORK \& NILES, 1998, pp. 213-232.

O’LOUGHLIN, J. L. N. “Beowulf- its unity and purpose”. Medium Aevum 21, 1952, p. 1-13.

OMAN, Charles. England before the Norman conquest, Londres: Methuen \& Co., 1949.

ORCHARD, Andy. A Critical Companion to Beowulf, Cambridge: D.S.Brewer, 2004.

PAGE, R. I. Runes, Los Angeles: California University Press, 1993. Chronicles of the Vikings, Londres: British Museum Press, 1995. “The Audience of Beowulf and the Vikings” In: CHASE, 1997, pp. 113-122.

POLLINGTON, Stephen. Wordcraft: Concise New English to Old English dictionary and thesaurus. Norfolk: Anglo-Saxon Books, 1993. 
ROESDAHL, Else. The Vikings, Londres: Penguin,1992.

ROGERS, H. L. “Beowulf’s Three Great Fights”, Review of English Studies 6, 1955, pp. 339-355 In: NICHOLSON, 1966, pp. 233-256.

RUMBLE, Alexander R. The Reign of Cnut, Londres: Leicester University Press, 1999.

RUSSELL, James C. The Germanization of Early Medieval Christianity, Oxford: Oxford University Press, 1994.

RUSSOM, Geoffrey R. "A Germanic concept of nobility in the Gifts of Men and Beowulf”, Speculum, 53/1, 1978, p. 1-15.

SAWYER, P. H. Kings and Vikings, Londres: Routledge, 1982.

The Oxford ilustrated History of the Vikings, Oxford, Oxford University Press, 1997.

SCHMITT, Jean-Claude. Il Gesto nel Medioevo, Roma: Ed. Laterza, 1999.

SCHÜCKING, Levin L. "Das Königsideal im Beowulf”, Bulletin of the Modern Humanities Research Association 3, 1929, pp. 143-154 In: NICHOLSON, 1966, pp. 35-50.

SCOWCROFT, R. Mark. “The Irish analogues to Beowulf”. Speculum, 74/1, 1999, p. 22-65.

SHIPPEY, Thomas A. “Structure and Unity” In: BJORK \& NILES, 1998, pp. 149-174.

SPINA, Segismundo. A cultura literária medieval, São Paulo: Ateliê Ed. 1997.

STENTON, Sir Frank M. Anglo-Saxon England, Oxford: Oxford University Press, 1989.

TOLKIEN, J. R. R. Finn and Hengest: The fragment and the episode, Londres: Harper Collins, 1982.

The monsters and the critics, Londres: Harper Collins, 1997.

TURVILLE-PETRE, E. O. G. Myth and religion of the North, Londres: Weidenfeld \& Nicolson, 1964.

VERNANT, Jean-Pierre. Entre Mito e Política, São Paulo: Edusp, 2002.

VEYNE, Paul. Did the Greeks believe in their myths? An Essay on the Constitutive Imagination, Chicago: Chicago University Press, 1988.

WHITE, Hayden. The Content of the Form. Narrative Discourse and Historical Representation, Baltimore: John Hopkins University Press, 1990.

WHITELOCK, Dorothy. The beginnings of English society, Aylesbury: Penguin, 1956.

The Audience of Beowulf, Oxford: Clarendon Press, 1964.

WILLIAMS, Ann. Kingship and Government in Pre-Conquest England c. 500-1066, Londres: MacMillan Press, 1999.

WOLF, Alois. "Medieval Heroic Traditions and their transitions from orality to literacy" In: DOANE \& PASTERNACK, 1991, pp. 67-88. 
WOODRUFF, Douglas. The Life and Times of Alfred the Great, Londres: Weidenfeld and Nicolson, 1993.

WORMALD, Patrick. “Anglo Saxon Society and its Literature” In: GODDEN, 1994, pp. 1-22 WRIGHT, Herbert G. “Good an Evil; Light and Darkness; Joy and Sorrow in Beowulf”, Review of English Studies 8, 1957, 1-11 In: NICHOLSON, 1966, pp. 257-268.

YORKE, Barbara. Kings and Kingdoms of Early Anglo-Saxon England, Londres: Routledge, 2002. 